NUREG / CR-2403

\title{
Survey of Insulation Used in Nuclear Power Plants and the Potential for Debris Generation
}

Manuscript Completed: April 1982

Date Published: May 1982

Prepared by

R. Kolbe, E. Gahan

Burns and Roe, Inc.

800 Kinderkamack Road

Oradell, NJ 07649

Under Subcontract to

Sandia National Laboratories

Albuquerque, NM 87185

Prepared for

Division of Safety Technology

Office of Nuclear Reactor Regulation

U.S. Nuclear Regulatory Commission

Washington, D.C. 20555

NRC FIN B6220

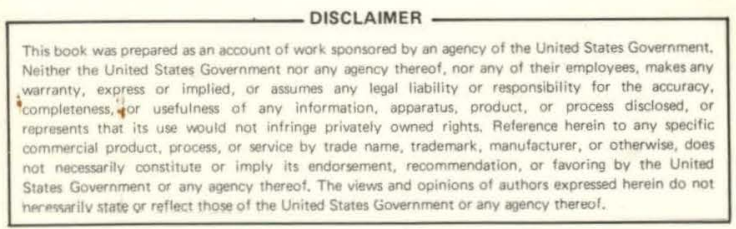

NOTICE

RTIONS OF TYIS REPORT ARE ILLEGIPTIE. It ..us been reproduced from tho best availablo copy to permit the broadest possible availability. 


\section{DISCLAIMER}

This report was prepared as an account of work sponsored by an agency of the United States Government. Neither the United States Government nor any agency Thereof, nor any of their employees, makes any warranty, express or implied, or assumes any legal liability or responsibility for the accuracy, completeness, or usefulness of any information, apparatus, product, or process disclosed, or represents that its use would not infringe privately owned rights. Reference herein to any specific commercial product, process, or service by trade name, trademark, manufacturer, or otherwise does not necessarily constitute or imply its endorsement, recommendation, or favoring by the United States Government or any agency thereof. The views and opinions of authors expressed herein do not necessarily state or reflect those of the United States Government or any agency thereof. 


\section{DISCLAIMER}

Portions of this document may be illegible in electronic image products. Images are produced from the best available original document. 


\section{The following pages are an exact representation of what is in the original document folder.}


This report was prepared by Burns and Roe, Inc. as an Account of Work sponsored by the Sandia National Laboratories (Albuquerque). Neither SNL, members of SNL, Burns and Roe, Inc., nor any person acting on behalf of either: (a) makes any warranty or representation, expressed or implied, with respect to the accuracy, completeness, or usefulness of the information contained in this report, or that the use of any information, apparatus, method, or process disclosed in this report may not infringe privately owned rights, or (b) assumes any liabilities with respect to the use of, or for damages resulting from the use of, any information, apparatus, method or process disclosed in this report. 
ABSTRACT

In support of Unresolved Safety Issue, USI A-43, "Containment Emergency Sump Performance," 8 additional nuclear power plants (representative of different U.S. reactor manufacturers and architect-engineers) were surveyed to identify and document the types and amounts of insulation used, location within containment, components insulated, material characteristics, and methods of installation and attachment. These plants were selected to obtain survey information on "older" plants and supplements information previously reported in NUREG/CR-2403. In addition, a preliminary assessment was made of the potential for migration to the emergency sump of the insulation debris which might be generated as a result of the postulated loss-of-coolant accident (pipe break). 
THIS PAGE

\section{WAS INTENTIONALLY \\ LEFT BLANK}




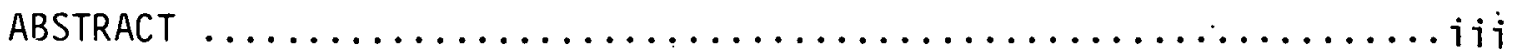

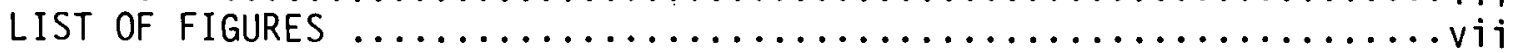

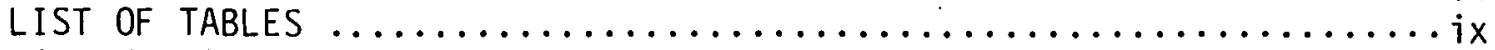

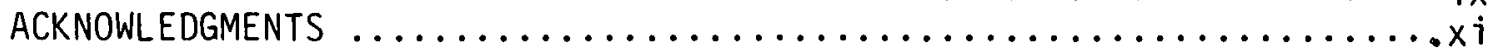

LIST OF ABBREVIATIONS $\ldots \ldots \ldots \ldots \ldots \ldots \ldots \ldots \ldots \ldots \ldots \ldots \ldots \ldots \ldots \ldots \ldots \ldots \ldots \ldots \ldots$

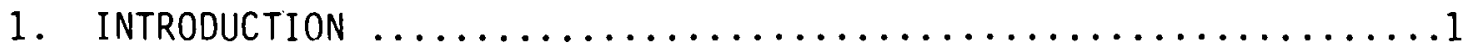

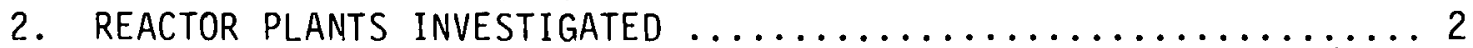

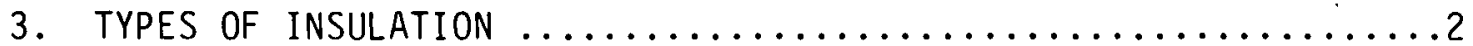

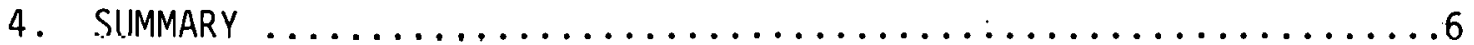

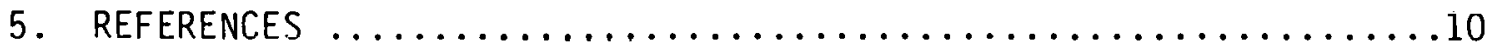

\section{APPENDICES}

Appendix A - Description of Insulation Found in

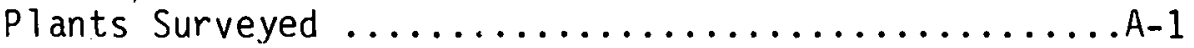

Appendix B - Millstone Unit 2: Preliminary Assessment of Insulation Debris Generated During a Pipe Break Even't ...............

Appendix C - St. Lucie Unit 1: Preliminary Assessment of Insulation Debris Generated During a Pipe Break Event ......................

Appendix D - Calvert Cliffs Units 1 and 2: Preliminary Assessment of Insulation Debris Generated During a Pipe Break Event ...................

Appendix E - Robert E. Ginna: Prel iminary As sessment of Insulation Debris Generated During a Pipe Break Event .........................

Appendix F - Prairie Island Units 1 and 2: Preliminary Assessment of Insulation Debris Generated During a Pipe Break Event ..................

Appendix G - Kewaunee: Preliminary Assessment of Insulation Debris Generated During a Pipe Break Event ............................

Appendix $\mathrm{H}$ - Haddam Neck: Preliminary Assessment of Insulation Debris Generated During a Pipe Break Event . $\mathrm{H}-1$

Appendix I - H.B. Robinson: Preliminary Assessment of Insulation Debris Generated During a Pipe Break Event 
THIS PAGE

\section{WAS INTENTIONALLY \\ LEFT BLANK}


Specially Designed Mirror Valve and Elbow Insulation for 24" Residual Heat Removal at Vermont Yankee Nuclear Station .............

Mirror Insulation $\ldots \ldots \ldots \ldots \ldots \ldots \ldots \ldots \ldots \ldots$

Typical Buckled Panel Arrangement

Typical Banded Panel Arrangement .............. 8

(a) Calcium Silicate Molded Block Insulation;

(b) Fiberglass Molded Block Insulation;

(c) Installed Calcium Silicate Insulation

A-6 Calcium Silicate or Unibestos Molded Block Jacketed Insulation .....................10

B-1 Reactor Building Elevation Arrangement, Millstone Unit 2 . B-5

B-2 Reactor Building Plan, Millstone Unit $2 \ldots . .$. B-6

B-3 Containment Sump, Millstone Unit $2 \ldots \ldots \ldots \ldots .6 .7$

C-1 Reactor Building Elevation, St. Lucie Unit $1 \ldots . . C-4$

C-2 Reactor Building Plan, St. Lucie Unit $1 \ldots \ldots . C-5$

C-3 Containment Sump, St. Lucie Unit $1 \ldots \ldots \ldots \ldots .6$

C-4 Containment Sump Isometric, St. Lucie Unit $1 \ldots . C-7$

D-1 Reactor Building Elevation, Calvert Cliffs, Units 1 and 2 ........................... 8

D-2 Reactor Building Plan, Calvert Cliffs

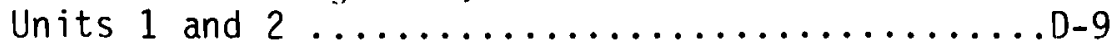

D-3 Containment Sump, Calvert Cliffs Units 1 and $2 \ldots$ - -10

E-1 Reactor Building Elevation, Robert E. Ginna ....E-6

E-2 Reactor Building Plan, Robert E. Ginna .......... E-7

E-3 Containment Sump, Robert E. Ginna ............ E-8 


\section{LIST OF FIGURES (Cont'd)}

Figure Number

$\mathrm{F}-1$

$F-2$

$F-3$

F. -4

G-1

G-2

G-3

G-4

$H-1$

$H-2$

$H-3$

I - 1

$I-2$

I -3
Reactor Building Elevation, Prairie Island

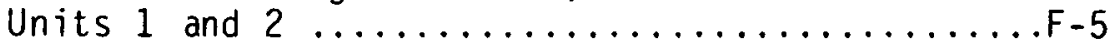

Reactor Building Plan, Prairie Island

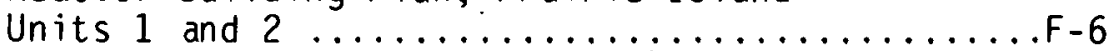

Containment Sump, Prairie Island Units 1 and 2 ..F-7

Containment Sump Isometric, Prairie Island

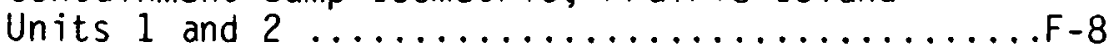

Reactor Building Elevation, Kewaunee .........G-6

Reactor Building Plan, Kewaunee .............

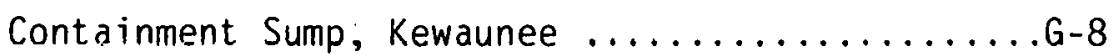

Containment Sump Isometric, Kewaunee .........G-9

Reactor Building Elevation, Haddam Neck .......H-5

Reactor Building Plan, Haddam Neck ............6

Containment Sump, Haddam Neck ................

Reactor Building Elevation, H.B. Robinson ......I-5

Reactor Building Plan, H.B. Robinson .........I-6

Containment Sump, H.B. Robinson ............. I-7 


\section{LIST OF TABLES}

Table

Page

$2-1$

Reactor Plants Selected for Insulation

Survey

3

$3-1$

Types and Percentages of Insulation Used

With in the Primary Coolant System Shield

Wall in Plants Surveyed $\ldots \ldots \ldots \ldots \ldots \ldots \ldots \ldots$

$4-1$

Summary Table

7 
THIS PAGE

\section{WAS INTENTIONALLY LEFT BLANK}


This report was prepared as part of the work under USNRC "Unresolved Safety Issue" A-43, "Containment Emergency Sump Performance." Its primary purpose is to assess the potential effects of insulation debris generated as the result of a loss-of-coolant accident (pipe break).

Burns and Roe wishes to express their appreciation to the following organizations for their help in supplying information.

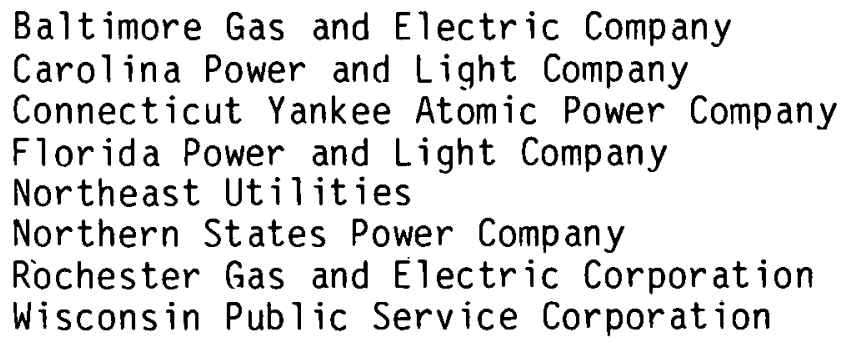

Particular acknowledgement is due to the valuable assistance and guidance provided by Mr. A.W. Serkiz, NRC Task Manager Generic Issues Branch, Division of Safety Technology and other NRC staff. 
THIS PAGE

\section{WAS INTENTIONALLY \\ LEFT BLANK}




\section{LIST OF ABBREVIATIONS}

$\begin{array}{ll}\text { ASME } & \text { American Society of Mechanical Engineers } \\ \text { BG\&E } & \text { Baltimore Gas and Electric } \\ \text { B\&R } & \text { Burns and Roe } \\ \text { CE } & \text { Combustion Engineering } \\ \text { CVCS } & \text { Chemical and Volume Control System } \\ \text { DST } & \text { Division of Safety Technology - USNRC } \\ \text { FSAR } & \text { Final Safety Analys is Report } \\ \text { LOCA } & \text { Loss-of-Coolant Accident } \\ \text { MWe } & \text { Megawatt Electrical } \\ \text { NRC } & \text { Nuclear Regulatory Commission } \\ \text { PWR } & \text { Pressurized Water Reactor } \\ \text { RBCCW } & \text { Reactor Building Closed Cooling Water } \\ \text { RC } & \text { Reactor Coolant } \\ \text { RCB } & \text { Reactor Containment Building } \\ \text { RCS } & \text { Reactor Coolant System } \\ \text { RG\&E } & \text { Rochester Gas and Electric Corporation } \\ \text { RV } & \text { Reactor Vessel } \\ \text { SNL } & \text { Sandia National Laboratories } \\ \text { SS } & \text { Stainless Steel } \\ \text { USNRC } & \text { United States Nuclear Regulatory Commission } \\ \text { W } & \text { Westinghouse }\end{array}$


SURVEY OF INSULATION USED

IN NUCLEAR POWER PLANTS

AND POTENTIAL FOR DEBRIS GENERATION

\section{INTRODUCTION}

The United States Nuclear Regulatory Commission (USNRC) Unresolved Safety Issue A-43, "Containment Emergency Sump Performance," deals with reactor containment building (RCB) emergency sump performance under post loss-of-coolant accident (LOCA) recirculation conditions 1 . This issue describes sump hydraulic performance (i.e., providing adequate net positive suction head to the recirculation pumps) and the effect of insulation debris generated in the course of the LOCA on the performance of the RCB emergency sump and the recirculation pumps.

The study was carried out under subcontract to Sandia Laboratories to identify and document the types and amounts of insulation, location with in the RCB, components insulated, material characteristics, and methods of installation and attachment for eight selected plants; and therefore, extends the plant data base previously reported in NUREG/CR-24032 "Survey of Insulation Used in Nuclear Power Plants and the Potential for Debris Generation" dated October 1981.

The three basic concerns of this additional plant survey were:

- Types of insulation used and arrangement of piping within the RCB in the vicinity of pipe breaks in high energy (i.e., primary system) fluid piping postulated for LOCA conditions

- Descriptive details of the insulation used and the type that could be dislodged, thereby becoming a source of debris as the result of a major pipe break

- Location and configuration of the sumps that serve as intakes for the emergency long-term recirculation core cooling, and the communicating paths by which insulation debris generated by a major pipe break could migrate to the sump

Plant design information was obtained for 8 plants representative of 2 U.S. reactor manufacturers. The selected sample consisted of plants designed by 5 architect-engineering firms for 8 utilities with plant startup dates ranging from 1968 to 1977; thereby providing information on the older plants. This work is a continuation of a survey originally performed for $11 \mathrm{plants,} \mathrm{both} \mathrm{operating} \mathrm{and} \mathrm{under} \mathrm{construction,}$ and reported previously in NUREG/CR-2403.

The information for each plant was assembled in a data package that included a preliminary insulation debris hazard analysis. These plant information packages are included as appendixes in this report. 


\section{REACTOR PLANTS INVESTIGATED}

Table 2-1 lists the plants selected by the Division of Safety Technology (DST) of NRC for conducting this generic insulation survey. Analys is of the design information was performed for all of these plants.

A letter was sent by NRC to these utilities listing the type of plant design and insulation documentation needed. Additional information or clarification was by Burns and Roe (B\&R) staff obtained by telephone.

The information requested was:

- Type and description of thermal insulation used for piping and equipment inside the RCB, including dimensional details

- Specification and contractor details for procurement and installation of insulation in the RCB

- Drawings of installation details of insulation including methods of attaching, spacing, and joining insulation

- Design drawings such as general arrangement drawings of the RCB; structural drawings of the RCB; drawings of piping inside the RCB including supports, restraints and anchors; flow diagrams of the systems that have piping inside the RCB; drawings that depict the RCB sumps, drainage to the sump, and protection for pump suction intakes; and drainage details in the RCB.

\section{TYPES OF INSULATION EMPLOYED}

Various types of thermal and antisweat insulation are used inside the RCB. Thermal insulation is used for reactor coolant, main steam, feedwater, and emergency core-cooling piping. Antisweat insulation is used for cooling-water, chilled-water, refrigerant, and cold-gas piping.

Types of thermal insulation found in use were:

- Reflective metallic insulation

- Totally encapsulated insulation with the following insulation filler types

Calcium silicate

Expanded perlite

Fiberglass

Mineral wool fiber 
TABLE 2-1. Reactor plants selected for follow-up insulation survey

\begin{tabular}{|c|c|c|c|c|c|}
\hline $\begin{array}{l}\text { Plant and } \\
\text { Location }\end{array}$ & Reactor & Rating & $\begin{array}{l}\text { Startup } \\
\text { Date }\end{array}$ & Utility & Architect-Engineer \\
\hline $\begin{array}{l}\text { Millstone Unit } 2 \\
\text { Waterford, Conn. }\end{array}$ & CE-PWR & 870 MWe & 1975 & Northeast Utilities & Bechtel \\
\hline $\begin{array}{l}\text { St. Lucie Unit } 1 \\
\text { Hutchinson Island, } \\
\text { Fla. }\end{array}$ & CE-JWR & 777 MWe & 1976 & $\begin{array}{l}\text { Florida Power } \\
\text { \& Light Co. }\end{array}$ & Ebasco \\
\hline $\begin{array}{l}\text { Calvert Cliffs } \\
\text { Units } 1 \& 2 \text { Lusby, } \\
\text { Md. }\end{array}$ & CE-PWR & 850 MWe & $1975^{\star}$ & $\begin{array}{l}\text { Baltimore Gas } \\
\text { \& Electric Co. }\end{array}$ & Bechtel \\
\hline $\begin{array}{l}\text { Robert E. Ginna } \\
\text { Ontario, N.Y. }\end{array}$ & W-PWR & 4900 MWe & 1970 & $\begin{array}{l}\text { Rochester Gas } \\
\& \text { Electric Corp. }\end{array}$ & Gilbert \\
\hline $\begin{array}{l}\text { Prairie Island } \\
\text { Units } 1 \& 2 \text { Red } \\
\text { Wing, Minn. }\end{array}$ & $W-P W R$ & 520 MWe & $1973^{\star \star}$ & $\begin{array}{l}\text { Northern States } \\
\text { Power Co. }\end{array}$ & $\begin{array}{l}\text { Fluor Power } \\
\text { Services }\end{array}$ \\
\hline $\begin{array}{l}\text { Kewaunee } \\
\text { Carlton, Wis. }\end{array}$ & W-FWR & 535 MWe & 1974 & $\begin{array}{l}\text { Wisconsin Public } \\
\text { Services Corporation }\end{array}$ & $\begin{array}{l}\text { Fluor Power } \\
\text { Services }\end{array}$ \\
\hline $\begin{array}{l}\text { Haddam Neck } \\
\text { Haddam Neck, } \\
\text { Conn. }\end{array}$ & W-PWR & 575 MWe & 1968 & $\begin{array}{l}\text { Connecticut Yankee } \\
\text { Atomic Power Co. }\end{array}$ & Stone \& Webster \\
\hline $\begin{array}{l}\text { H.B. Robinson } \\
\text { Hartsville, S.C. }\end{array}$ & $W-P W R$ & 665 MWe & 1971 & $\begin{array}{l}\text { Carolina Power } \\
\& \text { Light Co. }\end{array}$ & Ebasco \\
\hline
\end{tabular}

* Unit 2 startup date is 1977

**Unit 2 startup date is 1974

Source: Nuclear News, August 1981 


Cerablanket
- Mnibestos
- Mineral fiber blanket metal mesh covered
- Calcium silicate molded block jacketed insulation
- Unibestos or thermobestos molded block jacketed insulation
Types of antisweat insulation found in use were:

- Fiberglass jacketed insulation

- Urethane and polyurethane foam insulation

The early use of reflective metallic insulation in the reactor coolant system was limited to the reactor vessel because of the insulation's anticipated long life and the system's inaccessibility once it was installed inside the reactor shield wall. To fulfill the code requirement for inservice inspection of the reactor coolant and emergency core-cooling systems, removable reflective metallic insulation was tried and found satisfactory. Now some newer plants use this type of insulation exclusively in these systems. In addition, totally encapsulated removable insulation is being used in these systems. Mineral fiber blankets, calcium silicate molded blocks, and asbestos were the traditional choices in fossil power plants for hightemperature thermal insulation. Mineral fiber blankets were preferred for valves and equipment where access was needed for maintenance. Asbestos was used for thermal insulation because it is much sturdier than the calcium silicate block that has replaced it in modern stations because of the health hazard properties of asbestos.

Table 3-1 summarizes the types and percentages of each insulation utilized within the primary coolant system shield wall in the 8 plants surveyed. It shows that the older plants use a large amount of calcium silicate and unibestos block insulation compared to the newer plants which utilize mostly reflective metallic or totally encapsulated insulation. Appendix A describes each type of insulation.

Although some insulation used within the RCB is outside the primary coolant system shield wall, the survey considered only insulation inside the shield wall, because:

- The major portion of the insulation is within the shield wall.

- The location of a piping break that most likely would result in significant debris generation would be within the shield wall.

It should be recognized that the antisweat insulation (i.e. Fiberglass jacketed, urethane and polyurethane foam) is not shown in Table 3-1 
Table 3-1. Types and percentages of insulation used within the primary coolant system wall in plants surveyed

Types of Insulation and Percentage*

\begin{tabular}{|c|c|c|c|c|c|c|}
\hline Plant & $\begin{array}{c}\text { Reflective } \\
\text { Metallic } \\
\text { (Figs.A-1,2,3\&4) }\end{array}$ & $\begin{array}{c}\text { Totally } \\
\text { Encap- } \\
\text { sulated } \\
(\text { Fig. A-5) } \\
\underset{\star \star \star}{ }\end{array}$ & $\begin{array}{c}\text { Mineral } \\
\text { Fiber/Wool } \\
\text { Blanket }\end{array}$ & $\begin{array}{l}\text { Calcium } \\
\text { Silicate } \\
\text { Block } \\
(\text { Fig. } A-6) \\
\star \star \star \\
\text { (F) }\end{array}$ & $\begin{array}{l}\text { Unibestos \& } \\
\text { Thermobestos } \\
\text { Block } \\
(\text { Fig. } A-6) \\
\underset{\star \star \star}{ }\end{array}$ & Fiberglass \\
\hline Millstone Unit 2 & 25 & 35 & 5 & 30 & - & - \\
\hline St. Lucie Unit 1 & 10 & - & - & 90 & - & - \\
\hline $\begin{array}{l}\text { Calvert Cliffs } \\
\text { Units } 1 \& 2\end{array}$ & 41 & 59 & - & - & - & - \\
\hline Robert E. Ginna & - & - & 5 & 80 & 10 & 0 \\
\hline $\begin{array}{l}\text { Prairie Island } \\
\text { Units } 1 \text { \& } 2\end{array}$ & 98 & - & - & - & - & 2 \\
\hline Kewaunee & 61 & - & - & - & 39 & - \\
\hline Haddam Neck & 3 & - & - & - & $95 \star \star$ & 1 \\
\hline H. B. Robinson & - & - & - & 15 & 85 & - \\
\hline
\end{tabular}

* Tolerance is +20 percent

** Unibestos is currently being replaced by Calcium Silicate. However both types of insulation have the same sump blockage characteristics.

$\star \star \star$ See Appendix A for referenced figures. 
because the quantities of this type of insulation contained inside the shield wall were not judged to be significant (less than $2 \%$ ).

\section{SUMMARY}

Table 4-1 shows the types of insulation inside the RCB, the location of the emergency sump, a summary of the migration potential of debris to reach the emergency sump as a result of a pipe break for each plant studied and a preliminary assessment of potential for sump screen blockage. Data from 8 plants have been analyzed: 3 Combustion Engineering (CE) units, and 5 Westinghouse (W) units.

In Millstone Unit 2, it may be possible for some reflective metallic or totally encapsulated mineral wool to fall under the shield wall and onto the sump. Also, it is possible for calcium silicate and foam insulation to migrate to the sump. In St. Lucie Units $3 \& 4$, it may be possible for calcium silicate to migrate towards the sump during the initial flooding of the containment. In Calvert Cliffs Units 1 \& 2 , it is possible for some local reflective metallic and encapsulated mineral wool to fall onto the sump. In Robert E. Ginna, it. is possible for the asbestos, calcium silicate and fiberglass to migrate to the sump. In Prairie Island, some reflective metallic directly over the sump could fall onto it, and blanket insulation could migrate to the sump. In Kewaunee, some reflective metallic insulation could be transported towards the sump. Asbestos insulation because of its density, will float and migrate towards the sump. In Haddam Neck, the asbestos, calcium silicate, polyurethane and fiberglass could migrate towards the sump since it all floats. In H.B. Robinson, the possibility for insulation to reach the sump screen appears very limited because of the location of the sump and baffles surrounding it.

In general, all reflective metallic type of insulation sections or panels falling into containment will sink rapidly and most likely not be transported toward the emergency sump. 0ther types, including totally encapsulated with non-metallic inner materials, mineral wool, calcium silicate, unibestos, thermobestos, and fiberglass, can be expected to float initially, to migrate towards the emergency sump and to sink eventually. The rate and extent of water absorption, and thus the time to sink, will depend on such characteristics as the basic hygroscopicity of the material, cellular construction and design of the encapsulation. Discussion with insulation manufacturers (Owens-Corning, Pittsburg Plate Glass and Johns-Mansville) have indicated that meaningful information on water absorption and time to sink is not available; therefore, where non-metallic type insulations have been found in this survey, a potential for sump intake blockage has been indicated. The actual blockage, if any, for a given plant would depend upon determination of the exact insulation types used and their flotation characteristics, followed by an analys is using the methodology developed during this study. ${ }^{3}$ Separate investigations of flotation characteristics on a generic bas is for use in specific plant analyses may be desirable. It is understood that selective testing to determine such characteristics is being planned by the Alden Research Laboratories. 
TABLE 4-1. Summary Table

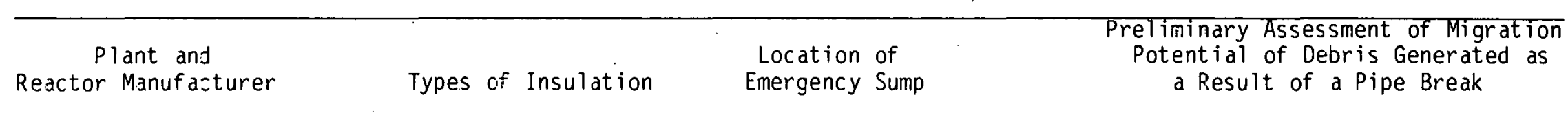

Metal jacketed or encapsulated calcium silicate block used almost exclusive 1y. Reactor coolant pump uses reflective metallic.

Reflective metallic has been used on the reactor coolant piping system, reactor vessel, steam generators, pressurizers and reactor cavity.

Encapsulated mineral wool has been used on the reactor coolant pumps, steam generators, pressurizer, regenerative heat exchanger, and reactor dome.
Millstone Unit $2 \quad$ Reflective metallic used

cavity. Encapsulated on reactor vessel. and

mineral. Nool used on

reactor zoolant system,

steam generator and pres-

surizer. Stainless steel

1 agged mineral wool used

on main steam and feed-

water pipe. Urethane foam

was used on component cool-

ing and calcium silicate on

remainder of systems..
Partially outside and under the reactor shield wall. (See Figure B-3)

Outside the shield wall in a trench surrounding the shield wall (see Figure $\mathrm{C}-2$ )

Calvert $\mathrm{Cl}$ iff

(CE)
Inside the reactor shield wall next to the reactor vessel wall (see Figure D-2)
Foam insulation could float towards the sump. The potential for a large amount of insulation to migrate to the sump is small.
The calcium silicate could float out of the shield wall and towards the sump during the initial flooding of the containment. The potential to block the sump screens exists. The reflective metallic appears to pose no problem.

Insulation from small diameter pipe over the sump could fall onto it. The potential for a large amount of insulation to migrate to the sump is small. 
TABLE 4-1. (Cont inued)

\begin{tabular}{ccc}
\hline Plant and & Location of & $\begin{array}{c}\text { Preliminary Assessment of Migration } \\
\text { Potential of Debris Generated as } \\
\text { a Result of a Pipe Break }\end{array}$ \\
\hline
\end{tabular}

Robert E. Ginna

Unit 1

(W)

Prairie Island

Units 1 \& 2

(W).

$\infty$
Calcium silicate used

almost exclusively.

Ceramic glass fiber

blankets are used on

removal sections.

Fiberglass is used

on service water cool-

ing system.

Reflective metallic is used throughout the plant. Pipe hanger and restraints are covered with fiberous glass

blankets.

Kewaunee Unit 1 (w)

Haddam Neck Unit 1 (W)

,

Reflective metallic is used almost exclusivly. Thermobestos is used to cover water piping.

Thermobestos insulation was used on the reactor
Below part of the shield wall and the reactor refueling channel (see

Figure E-2). the bulk of steam generators, main steam and feedand hot pipes. Fiberglass insulation was used at valves and welds. Foam insulation was used for cold water pipes. The reactor vessel is also covered in small part by reflective metallic.
Located outside the shield wall (see Figure $\mathrm{F}-2$ ).

Outside shield wall (see Figure G-2)

Inside crane wall next to fuel transfer channel (see Figure $\mathrm{H}-2$ ).

Calcium silicate could float towards the sump and then sink. There exist numerous insulated pipe and equipment items in the vicinity of the sump. The potential to block the screens exists.

Fibrous glass blankets could float and migrate to the sump. There are some small pipes over the sump.

Insulation from these pipes could fall onto the sump. Potential for a large amount of insulation to migrate to the sump is small.

Thermobestos could float and migrate to the sump and sink. Insulation could be dislodged from pipe in the vicinity of the sump and fall onto it. The potential to block the screens exists.

The thermobestos and fiberglass insulation could float and migrate to the sump and sink. The potential to block the screens exists. 
TABLE 4-1. (Cont inued)

\begin{tabular}{|c|c|c|c|}
\hline $\begin{array}{c}\text { Plant and } \\
\text { Reactor Manuf acturer }\end{array}$ & Types of Insulation & $\begin{array}{l}\text { Location of } \\
\text { Emergency Sump }\end{array}$ & $\begin{array}{c}\text { Preliminary Assessment of Migration } \\
\text { Potential of Debris Generated as } \\
\text { a Result of a Pipe Break }\end{array}$ \\
\hline$\underset{(W)}{H .}$ B. Robinsor & $\begin{array}{l}\text { Unibestos was originally } \\
\text { used for all equipment } \\
\text { and systems. Approxi- } \\
\text { mately, } 15 \text { percent of } \\
\text { the unitestos has been } \\
\text { replaced by calcium }\end{array}$ & $\begin{array}{l}\text { Along the outer edge } \\
\text { of shield or crane } \\
\text { wall (see Figure I-2). }\end{array}$ & $\begin{array}{l}\text { There exists little possibility for } \\
\text { insulation to reach the sump from } \\
\text { inside the shield wall because of } \\
\text { screens covering drainage openings. } \\
\text { Outside the shield wall, a set of } \\
\text { baffles protect the sump screens. }\end{array}$ \\
\hline
\end{tabular}


5. REFERENCES

1.

U.S. Nuclear Regulatory Commission, "Containment Emergency Sump Performance," USNRC Unresolved Safety Issue A-43, January 16, 1981. Available in the NRC Public Document Room for inspection and copying for a fee.

2.

U.S. Nuclear ReguTatory Commission, "Survey of Insulation Used in Nuclear Power Plants and the Potential for Debris Generation, " NUREG/CR-240.3, October 1981.

3. Burns and Roe, Inc., "Methodology for Evaluation of Insulation Debris Generation," prepared under Sandia Laboratories contract 61-4219, December 1981. 
APPENDIX A

DESCRIPTION OF INSULATION FOUND IN PLANTS SURVEYED

A description of each type of insulation found from the survey in each of the 8 plants follows.

\section{A. RELECTIVE METALLIC INSULATION}

Metallic all-metal removable insulation is provided primarily by Diamond Power Specialty Company and Transco to the utility industry for the primary coolant system, the reactor vessel, piping and equipment, and American Society of Mechanical Engineers (ASME) Section III $\mathrm{Cl}$ ass 2 components and equipment. This type of insulation controls heat loss and enables the owner/operator to comply with the inservice inspection requirements of ASME Code Section XI1 because it is easily removed. Reflective insulation is constructed in various combinations of materials ranging from all stainless steel to a combination of aluminum and stainless steel. (See Figure A-1.)

The insulation used for piping is typically 2 feet or longer in length, 3 to 4 in. thick, and split into two sections with each section covering half of the pipe. These sections are composed of 24-to 28-gauge stainless steel outer sheets which fully enclose 2 to $6 \mathrm{mil}$ stainless or aluminum sheets. The inner sheets are built up of two to three sheets per inch of insulation thickness. (See Figure A-2.)

The insulation panels used for large equipment such as the reactor vessel, pressurizer, and steam generators are typically 2 by $6 \mathrm{ft}$ and have a construction similar to the insulation described for piping. (See Figures $A-3$ and $A-4$. )

All panels on piping and equipment welds that require inservice inspection are fastened by quick release buckle bands for ease of removal. Nonremovable insulation panels are fastened, one to another, with self-tapping screws.

Diamond Power Specialty Company 2 has conducted tests of the response of their reflective insulation to loss-of-coolant accident (LOCA) conditions. Based on these tests, Diamond Power concluded that in a LOCA:

- All-Metal reflective insulation will be crushed instantly near pipe breaks because of the external differential pressure

- All-Metal reflective insulation sections or panels in line with the jet from a pipe break will be blown off the pipe or vessel because of the internal differential pressure that would develop

- All-Metal reflective insulation sections or panels in the immediate vicinity of a pipe break will be transported by the steam or air flow 
- All-Metal reflective insulation sections or panels falling into containment will sink rather than be transported because of low velocity to the emergency pump.

\section{B. TOTALLY ENCAPSULATED INSULATION}

Diamond Power, Transco, and Johns-Manville produce encapsulated insulation that is used on pressurizers in combination with reflective insulation. The construction of the totally encapsulated modules is exactly the same as that of reflective ones, except that a nonreflective material is used between the inner and outer casings instead of stainless steel. The type of insulation used between the casings for the different plants surveyed was as follows.

Calcium Silicate Molded Block

Calcium silicate molded block insulation is a molded, high-temperature pipe and block insulation composed of hydrous calcium silicate. It is light weight, has low thermal conductivity, and high structural strength, and is insoluble in water. Its density (dry) is 13 to 14 1b. per cubic foot. Its transverse strength (based on $1-1 / 2$ in. thickness) is 35 to 60 psi. Its compressive strength (based on 1-1/2 in. thickness) is 60 to $250 \mathrm{psi}$. The molded blocks are provided in thicknesses of up to $4 \mathrm{in}$. and lengths of up to $3 \mathrm{ft}$. (See Figure A-5.)

\section{Expanded Perlite Molded Block}

Expanded perlite molded block insulation is composed of expanded perlite with reinforced mineral fiber and inorganic binders. It is an insulating material with properties similar to those of calcium silicate insulation. The average maximum density is $14 \mathrm{lb}$. per cubic foot. Its flexural strength should be not less than $35 \mathrm{psi}$, and its compressive strength dry is $60 \mathrm{psi}$ and wet is $25 \mathrm{psi}$.

Fiberglass Molded Block

Fiberglass molded block insulation is composed of glass that has been foamed or cellulated under molten conditions, annealed, and set to form a rigid incombustible material with hermetically sealed cells. The density is between 7.0 and $9.5 \mathrm{lb}$. per cubic foot. Its flexural strength is $60 \mathrm{psi}$, and compressive strength is $75 \mathrm{psi}$. The water vapor permeability is 0.005 perm-in. Water absorption is 0.5 percent by volume. (See Figure A-5.)

Mineral Wool Fiber Block

Mineral wool fiber block insulation is made of a mineral substance, such as rock, slag, or glass processed from a molten state into fibrous form. The density, depending on kind, ranges from 10 to 20 1b. per cubic foot. The strength varies considerably with the classes of insulation. The moisture is less than 1.0 percent by volume. 
Cerablanket

Cerablanket (trade name), manufactured by Johns-Manville, is a ceramic fibrous insulating material with a density of $61 \mathrm{~b}$. per cubic foot. The Cerablanket is enclosed in 0.006 in. metal foil and then encapsulated in a reflective insulation structure.

Unibestos

Unibestos insulation is composed of lime and diatomaceous silica taken from natural deposits. These basic ingredients are bonded with asbestos fiber possessing the tensile strength of piano wire. This composition is then encased in stainless steel sheet.

\section{MINERAL FIBER BLANKET METAL MESH COVERED}

Mineral fiber blanket metal mesh covered insulation consists of blanket thermal insulation covered by flexible metal-mesh facings on one or both sides, and held together by heat-resistant ties extending from one face to the other. Rolls or flat sheets of blanket are usually 4 by $8 \mathrm{ft}$. With densities between 3 and $121 \mathrm{~b}$. per cubic foot, and thicknesses of up to 2 in.

\section{MINERAL FIBER/WOOL BLANKET JACKETED WITH ASBESTOS CLOTH}

Mineral fiber/wool blanket jacketed with asbestos cloth consists of a blanket insulating material of mineral wool or refractory mineral fiber covered with an inner cover of asbestos cloth and an outer cover of fine mesh glass cloth. The density of the blanket material is between 3 and $12 \mathrm{lb}$. per cubic foot. Blankets are secured with hooks and hog rings.

\section{E. CALCIUM SILICATE MOLDED BLOCK JACKETED INSULATION}

Calcium silicate molded block jacketed insulation has been utilized in a number of plants. The jacketing used is fiberglass cloth, stainless steel, or aluminum. Joints are sealcd against the entrance of water by sealing compounds. The properties of calcium silicate have been described previously. (See Figure A-6.)

\section{F. UNIBESTOS OR THERMOBESTOS MOLDED BLOCK JACKETED INSULATION}

Unibestos or thermobestos molded block jacketed insulation is composed of lime and diatomaceous silica taken from natural deposits estimated to be millions of years old. These basic ingredients are bonded with asbestos fibers possessing the tensile strength of piano wire. Basically, this type of insulation is. calcium silicate held together by asbestos fibers. Since asbestos is now banned for use by the Occupational Safety and Health Act, insulation using this material is no longer manufactured. This insulation is remarkably strong and rigid and, therefore, does not require metal jacketing. It is extremely light, with a density of $11 \mathrm{lb}$. per cubic foot, and not damaged 
by water. At some plants, unibestos is used but jacketed with fiberglass cloth or stainless steel sheets. (See Figure A-6.)

\section{G. FIBERGLASS JACKETED INSULATION (ANTISWEAT)}

Fiberglass insulation with metal jacketing is a rigid fiberglass pipe insulation made from long, flame-attenuated glass fibers with a thermosetting resin. The polished metal jacket is made of 0.016 in. aluminum or 0.010-in. stainless steel and usually has a longitudinal seam closure that locks the insulation and jacket in place. The insulation with jackets is produced in 3-ft. lengths. The density of, the fiberglass ranges from 7.0 to 9.5 lb. per cubic foot.

\section{H. URETHANE AND POLYURETHANE FOAM INSULATION (ANTISWEAT)}

Urethane and polyurethane foam antisweat insulation is a rigid cellular foam plastic that combines light weight and strength with exceptional thermal insulating efficency. The foam is a vast cross-linked network of closed cells, each cell a tiny bubble full of gas that accounts for 90 percent of its volume. Its density ranges from 1.8 to 4.0 per cubic foot. The insulation is sealed with a vapor barrier of aluminum foil or a metal jacket.

\section{REFERENCES}

1. ASME Boiler \& Pressure Vessel Code, Section XI, 1980, "Rules for Inservice Inspection of Nuclear Power Plant Components," ASME, New York, N.Y.

2. Diamond Power Specialty Company, "Response of Mirror Insulation to LOCA Conditions," Diamond Power Specialty Company Report, May 30, 1978. 


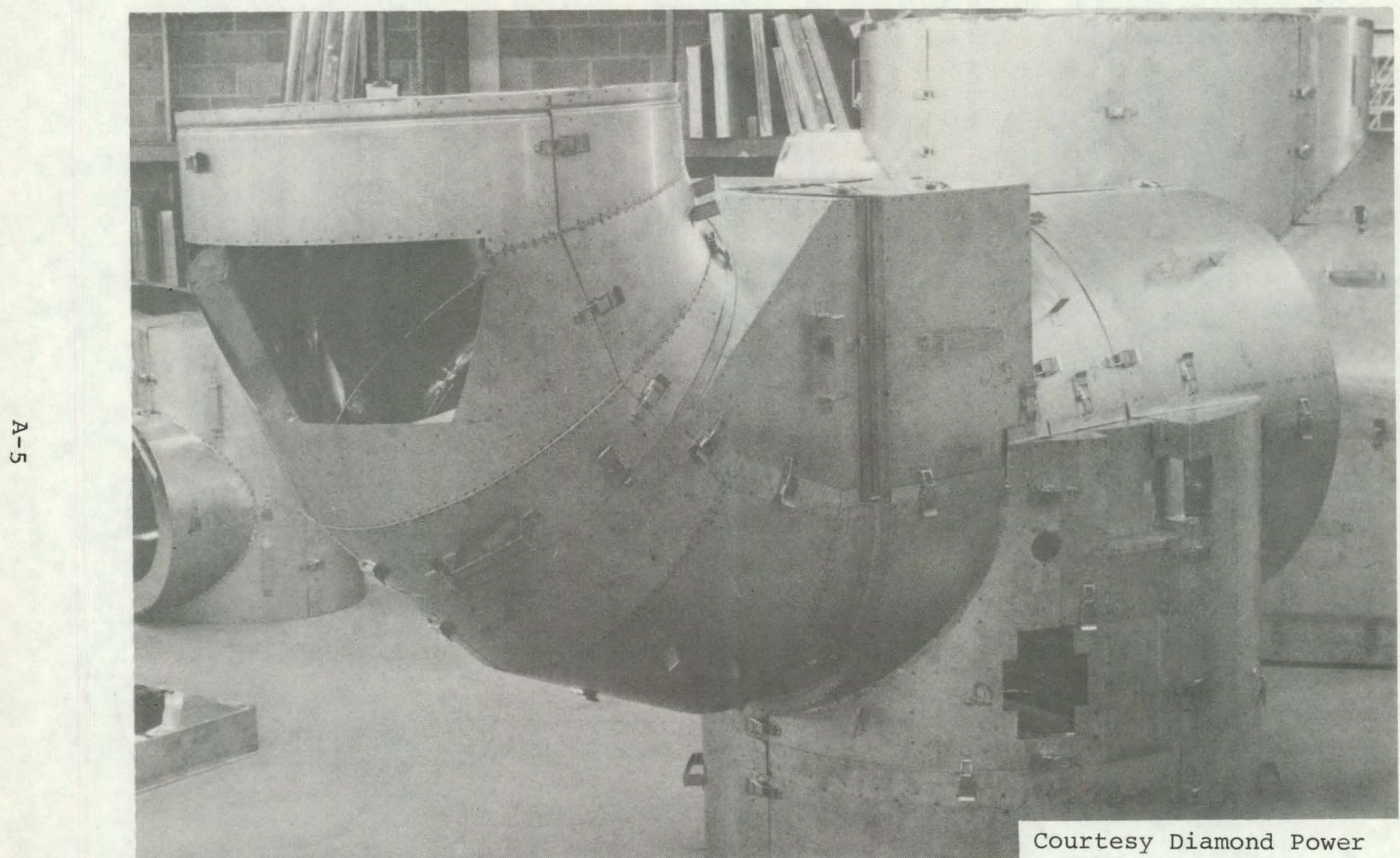

Figure A-1. Specially designed Mirror valve and elbow insulation for 24 " residual heat removal at Vermont Yankee Nuclear Station. 


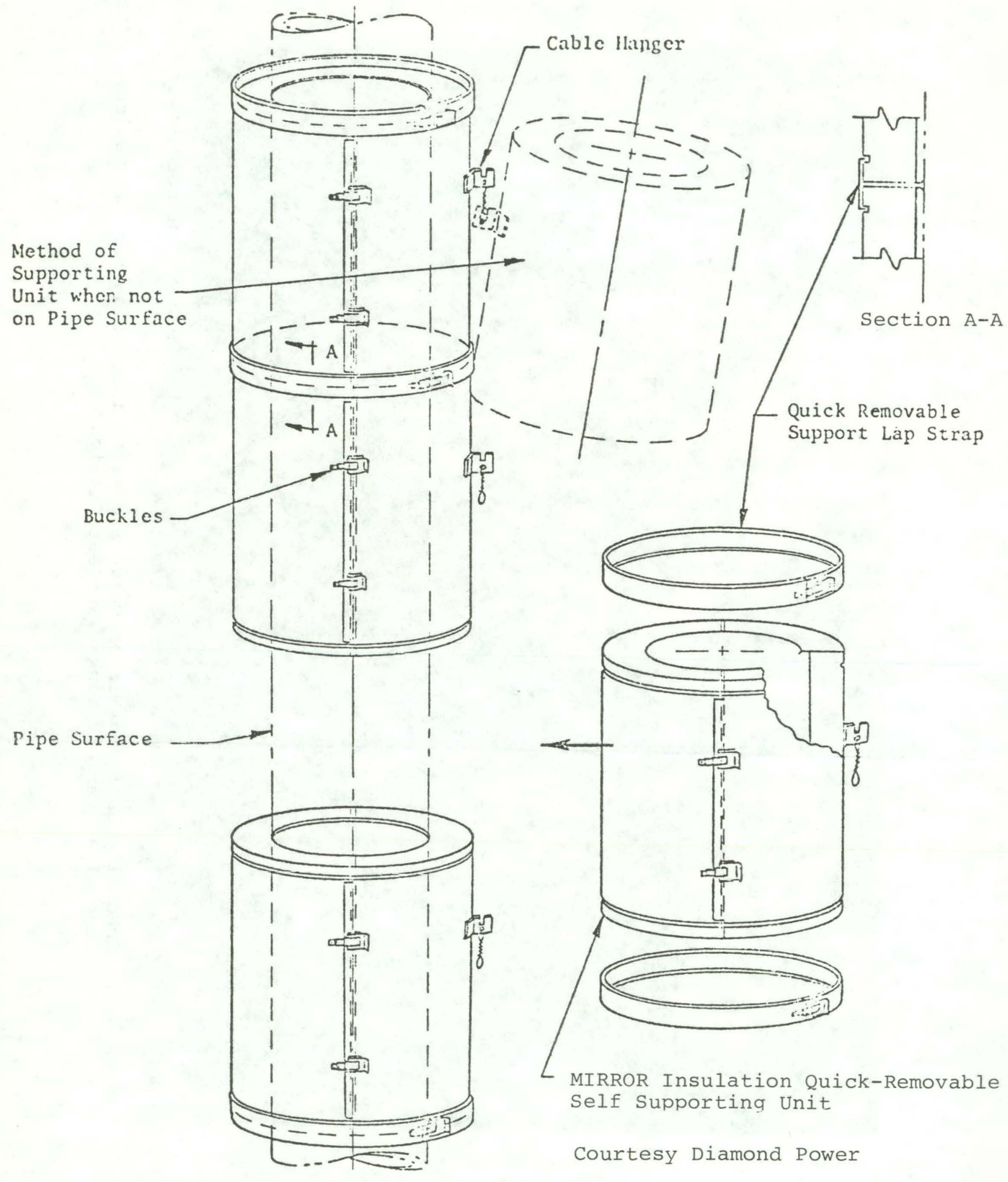

Figure A-2. MIRROR Insulation 


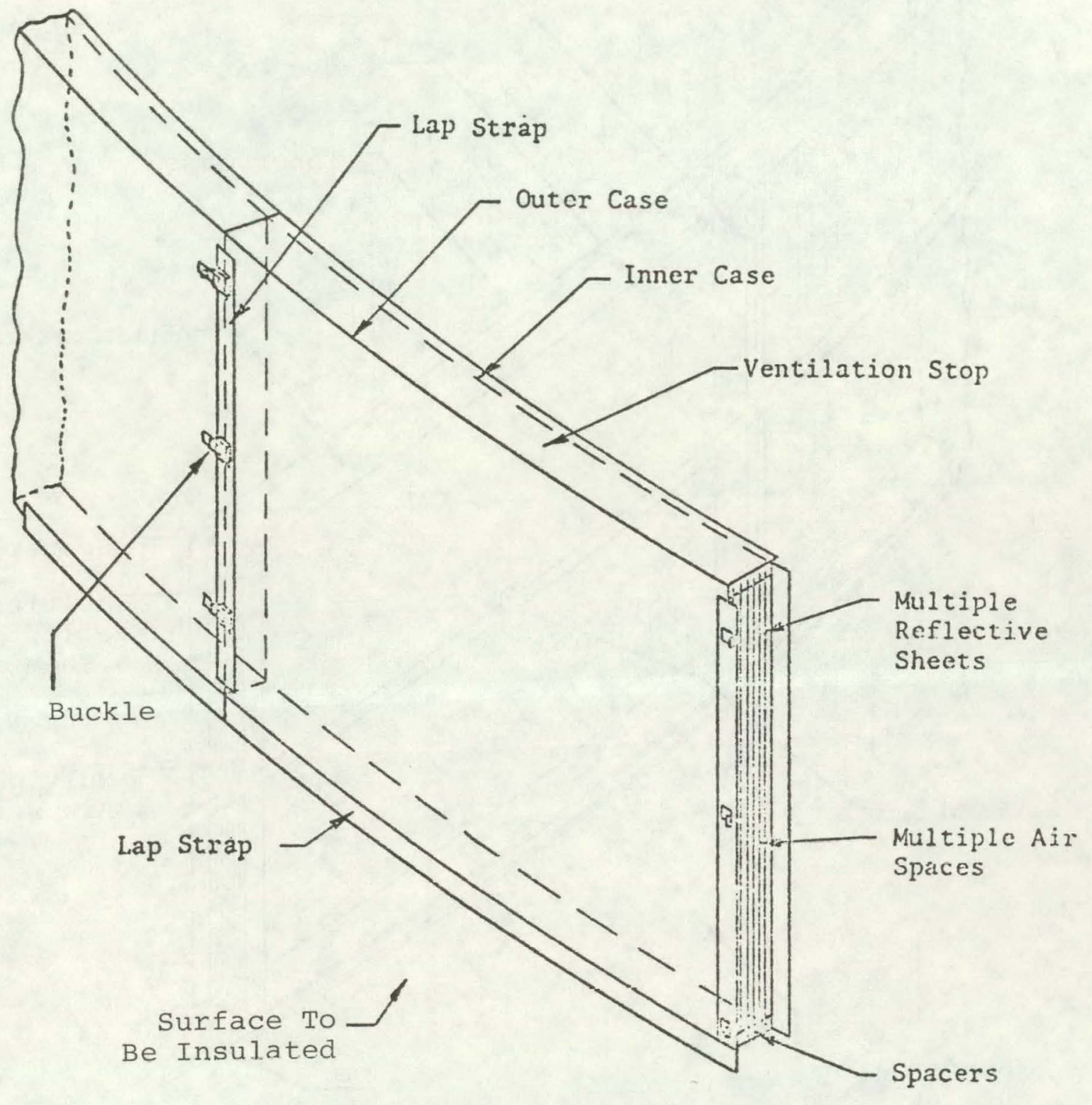

Courtesy Diamond Power

Figure A-3. Typical buckled panel arrangement 


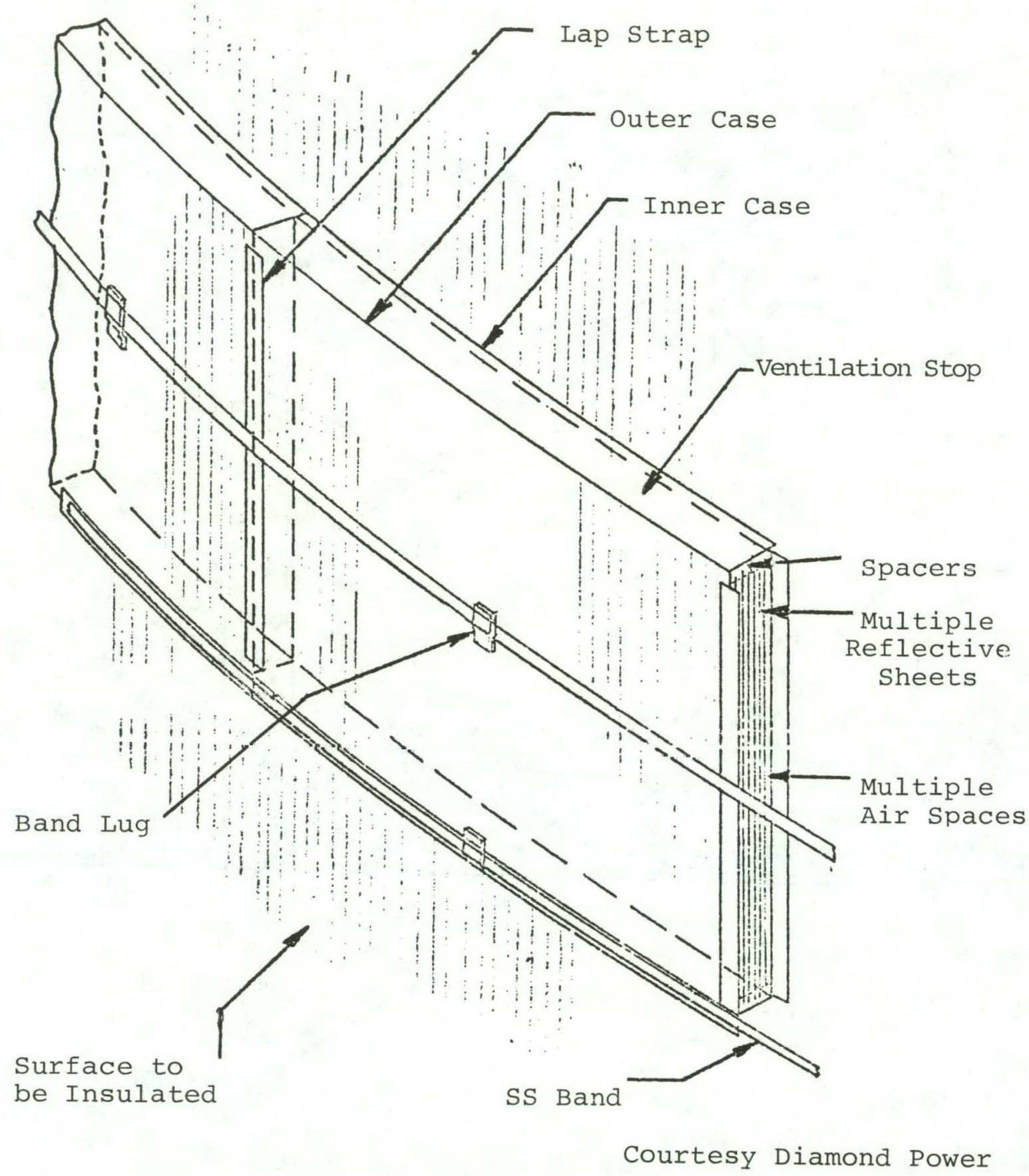

Figure A-4. Typical banded panel arrangement 


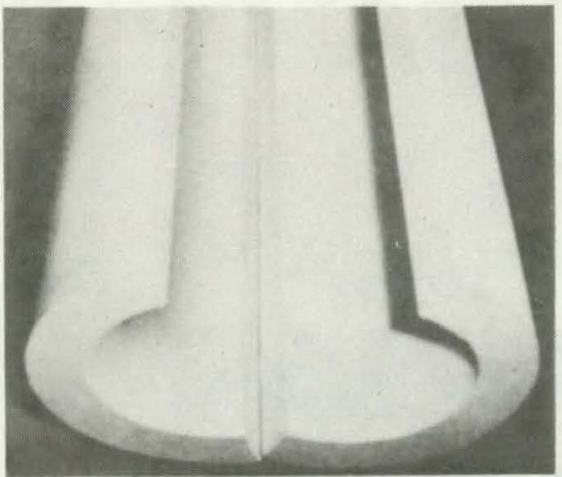

(a)

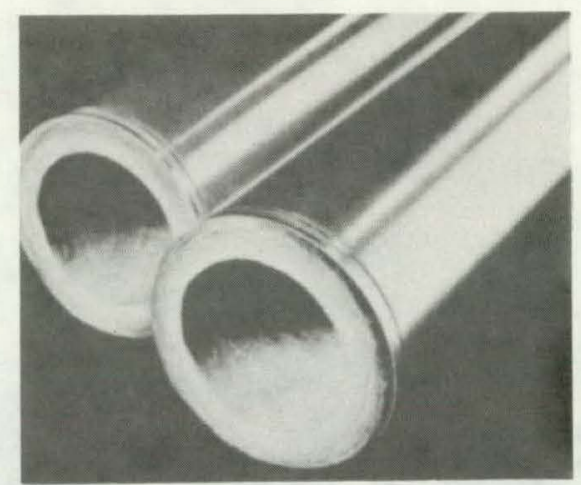

(b)

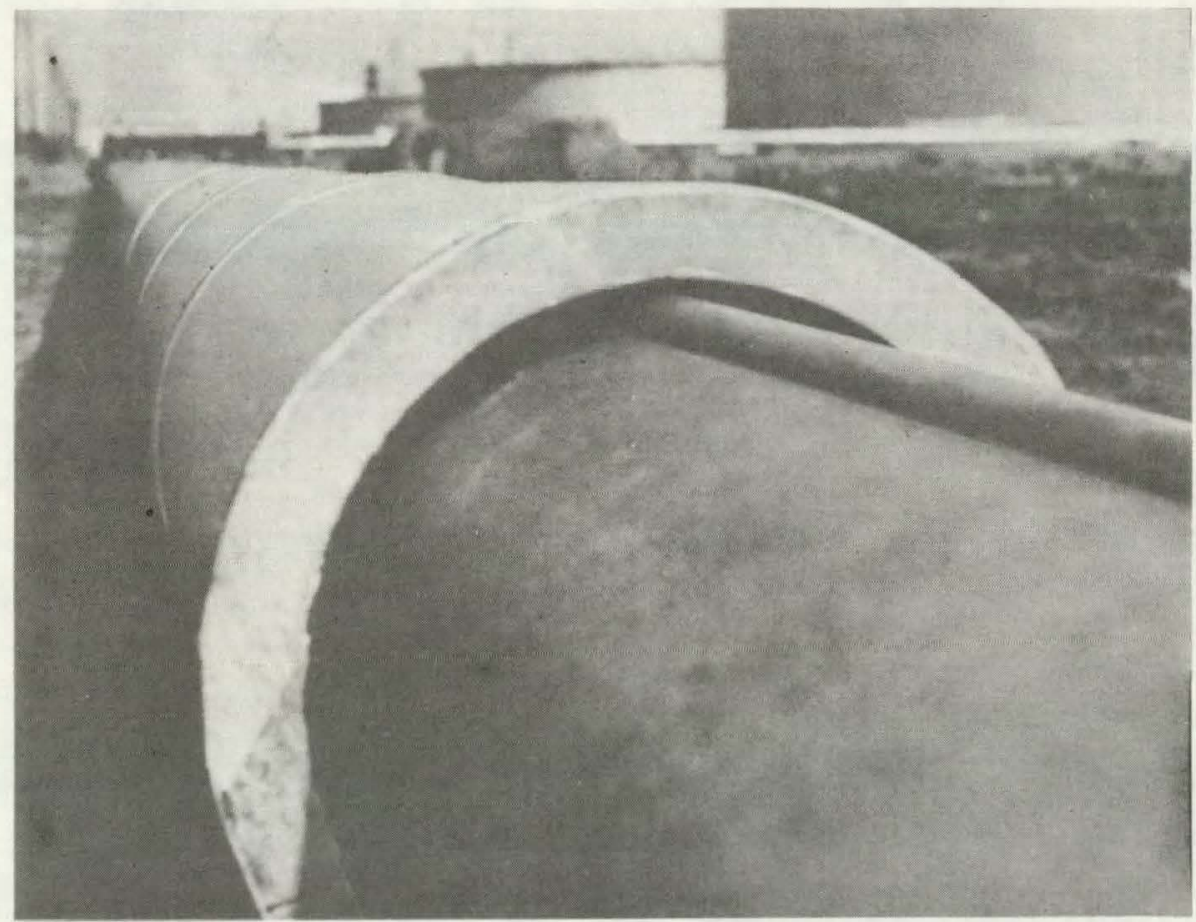

(c)

Figure A-5. (a) Calcium silicate molded black insulation;

(b) Figerglass molded block insulation;

(c) Installed calcium silicate insulation.

Courtesy Owens Corning Fiberglas Corp. 


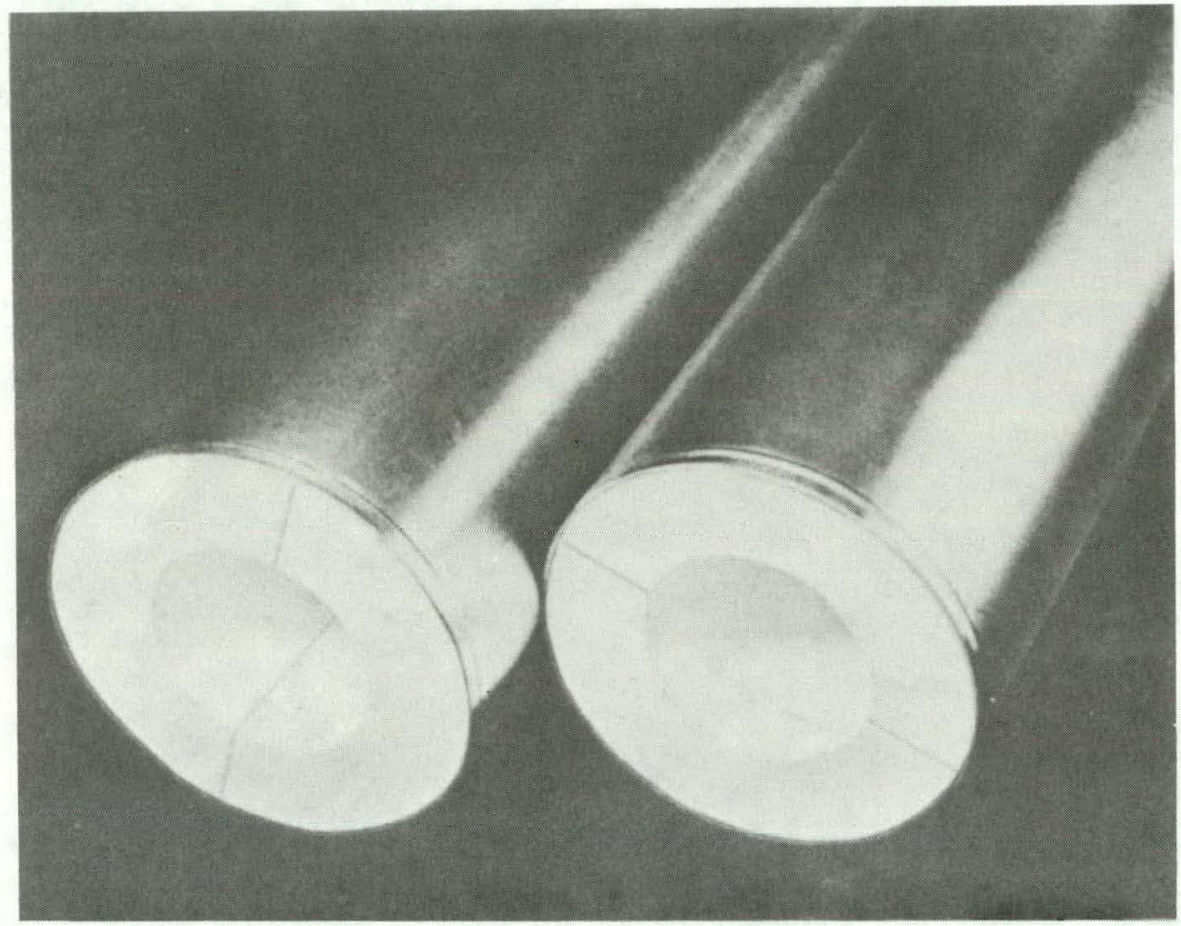

Courtesy Owens Corning Fiberglas Corp.

Figure A-6. Calcium silicate or unibestos molded block jacketed insulation 
APPENDIX B

MILLSTONE UNIT 2

PREL IMINARY ASSESSMENT OF

INSULATION DEBRIS GENERATED DURING $A$

PIPE BREAK EVENT 


\section{A. INTRODUCTION}

This report documents the information gathered by Burns and Roe's survey of thermal insulation inside the primary containment of the 870 MWe, Combusion Engineering, PWR, Millstone Unit 2 which started commercial operation in 1975.

The information gathered depicts the following:

1. The arrangement of all piping within the primary containment including high energy fluid piping

2. The location and configuration of the emergency intake sump for emergency core cooling, and the communicating paths by which debris generated by a major pipe break could reach the emergency recirculating sump

3. Details of the insulation that could be dislodged and become a source of debris as a result of a major break.

Five types of insulation are utilized within the containment. These are:

Reflective metallic has been used on the reactor vessel and cavity. Encapsulated mineral wool has been used on the reactor coolant system, steam generator and pressurizer. Mineral wool lagged with stainless steel has been used on the main steam and feedwater

lines. Urethane foam was used on cooling system pipe and calcium silicate on the balance of pipe.

\section{B. LISTING OF INPUT ORAWINGS AND OTHER DOCUMENTS}

This section provides a listing of drawings and documents showing details of containment and reactor building piping, flow diagrams, emergency sump details and insulation details for Millstone.

1. Documentation

a. Letter from Northeast Utilities to NRC dated December 29, 1980 on Containment Sump - Information Request.

2. Drawings

a. General Arrangement - Containment and Reactor Building

\begin{tabular}{|c|c|}
\hline $25203-27014$ & 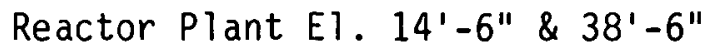 \\
\hline $25203-27018$ & $\begin{array}{l}\text { Reactor Plant E1. (-)5'-0" \& } \\
(-) 3^{\prime}-6^{\prime \prime}\end{array}$ \\
\hline $25203-27.019$ & $\begin{array}{l}\text { Reactor Plant El. (-)25'-6" \& } \\
(-) 22^{\prime}-6^{\prime \prime}\end{array}$ \\
\hline
\end{tabular}


25203-27020

Reactor Plant E1. (-)45'-6"

25203-27021

Reactor Plant Section "A-A"

b. Piping and Instrument Diagrams

25203-26002

25203-26005

25203-26014

25203-26015

25203-26017

25203-26022

Sh. 1 of 2

25203-26022

Sh. 2 of 2

c. Piping Layout Drawings

25203-20035

25203-20036

25203-20037

25203-20038

25203-20039

25203-20040
Main Steam and Reheat

Condensate and Feedwater System

Reactor Coolant System

Safety Injection System and Containment Spray System

Chemical and Volume Control System

R.B.C.C.W. System

R.B.C.C.W. System

Piping Plan - El. (-)22'-6"

Piping Plan - El. (-) $3^{\prime}-6^{\prime \prime}$

Piping Plan - E1. 14'-6"

Piping Plan - El. 38'-6"

Piping Sections "A-A" and "B-B"

Containment Penetration Piping Details

C. LISTING OF PIPING INSIDE CONTAINMENT CONTAINING INSULATION

This section provides a list of the equipment and systems inside primary containment containing insulation. The list includes the equipment, the system, nominal pipe sizes inside containment and the type of insulation used for each system. 


\begin{tabular}{|c|c|c|}
\hline System & $\begin{array}{l}\text { Diameter } \\
\text { Inches }\end{array}$ & Type of Insulation \\
\hline $\begin{array}{l}\text { Safety Injection } \\
\text { Pressurizer Surge Line } \\
\text { Reactor Coolant } \\
\text { Pressurizer Spray Line } \\
\text { Shutdown Cooling } \\
\text { Feedwater } \\
\text { Main Steam } \\
\text { Component Cooling }\end{array}$ & $\begin{array}{c}12 \\
12 \\
42,30 \\
3 \\
12 \\
18 \\
34 \\
6,4,3\end{array}$ & $\begin{array}{l}\text { Calcium Silicate } \\
\text { Calcium Silicate } \\
\text { Encapsulated Mineral Wool } \\
\text { Calcium Silicate } \\
\text { Calcium Silicate } \\
\text { Mineral Wool Lagged with SS } \\
\text { Mineral Wool Lagged with SS } \\
\text { Urethane Foam }\end{array}$ \\
\hline
\end{tabular}

Equipment Inside

Primary Containment

Reactor Vessel

Steam Generator

Pressurizer.

Reactor Coolant Pumps
Reflective Metallic

Encapsulated Mineral Wool

Encapsulated Mineral Wool

Encapsulated Mineral Wool

D. TYPICAL INSULATION DETAILS

Two mineral wool types of insulation are used within the containment building. One type is the totally enclosed stainless steel panels. The other type is mineral wool lagged with stainless steel which was used only on the main steam and feedwater lines. No metal lagged mineral wool was used on pipes below the $38^{\prime}-6^{\prime \prime}$ elevation.

The hydrous calcium silicate used is molded sections covered with sheet stainless steel. The reflective metallic insulation was described in Appendix A.

\section{E. PIPE BREAK LOCATIONS}

Refer to the FSAR ${ }^{1}$ for a list of the pipe break locations for high energy piping inside the primary containment.

\section{F. FSAR REFERENCES ON PERTINENT INSULATION QUESTIONS}

Northeast Utilities submitted answers to several questions regarding the insulation debris problem. The question numbers relating to this problem are.6.1, 6.29 and 6.33. The answers to these questions can be found in the FSAR. Question 6.1 requested intormation about the sump design details, while, Question 6.29 requested information about the configuration of the suction lines for recirculation. The answer to Question 6.33 provides an evaluation of the maximum amount of insulation which could be dislodged during a lossof-coolant accident. 


\section{G. PRELIMINARY INSULATION DEBRIS HAZARDS ANALYSIS}

Figures B-1 and B-2 are simplified sketches of the Millstone Unit 2 reactor containment. The reactor vessel, steam generators, pressurizers and associated piping are all located inside the shield wall. The emergency sump is located partially under the shield wall and extends outside the shield wall. The location of the emergency sump on the basement floor at El. $(-) 22^{\prime}-6^{\prime \prime}$ is shown in Figure B-2. Figure B-3 shows the detail of the emergency sump. The sump is divided into two parts and a separate intake pipe from each part goes to the emergency core cooling system. The sump is surrounded by a $3^{\prime}-9^{\prime \prime}$ high $7^{\prime} \times 12^{\prime}$ screen to catch debris. The screen and and the wall dividing the sump is constructed of 1-1/4" grating protecting \#3-3/4 wire mesh cloth calendered .080" wire, .187 opening. The wire mesh cloth is fastened to the inside of the grating with 1/4" bolts and washers.

For pipe breaks inside the shield wall, the potential for a large amount of insulation to migrate towards the sump is very small. A grate floor exists at El. 2'-6" and a concrete floor exists at El. $\left(-10^{\prime}-71 / 3^{\prime \prime}\right.$. These floors would catch most of the insulation. Similarly, outside the shield wall the potential problem is very small. Three floors exist at EI. 36' $-6^{\prime \prime}, 14^{\prime}-6^{\prime \prime}$ and $\left(-13^{\prime}-6^{\prime \prime}\right.$, which would catch most of the insulation. However, a small amount of insulation could migrate down the stairwells and other openings.

For pipe breaks inside the shield wall helow El, (-) $0^{\prime}-7$ 1/3" or outside the shield wall below El. (-) $3^{\prime}-6^{\prime \prime}$, the insulation debris could migrate to the sump. The least likely insulation to reach the sump is the mineral wool lagged with stainless steel since it is not used below 38'-6" elevation. The foam insulation would float. The reflective metallic and totally encapsulated mineral wool would sink.

H. REFERENCE

1. Millstone Unit 2, Final Safety Analys is Report, Northeast Utilities, Berlin, CT. 


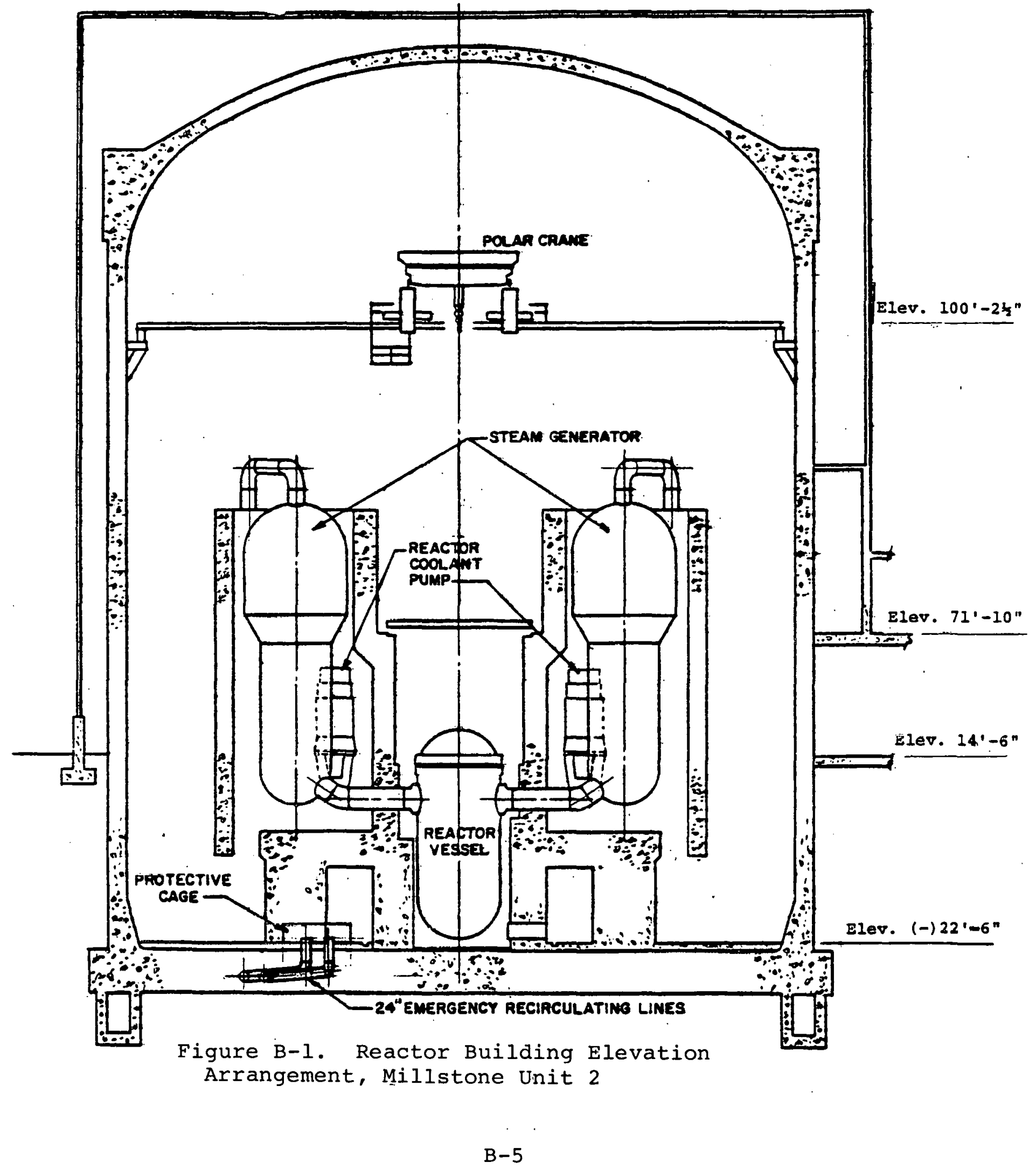




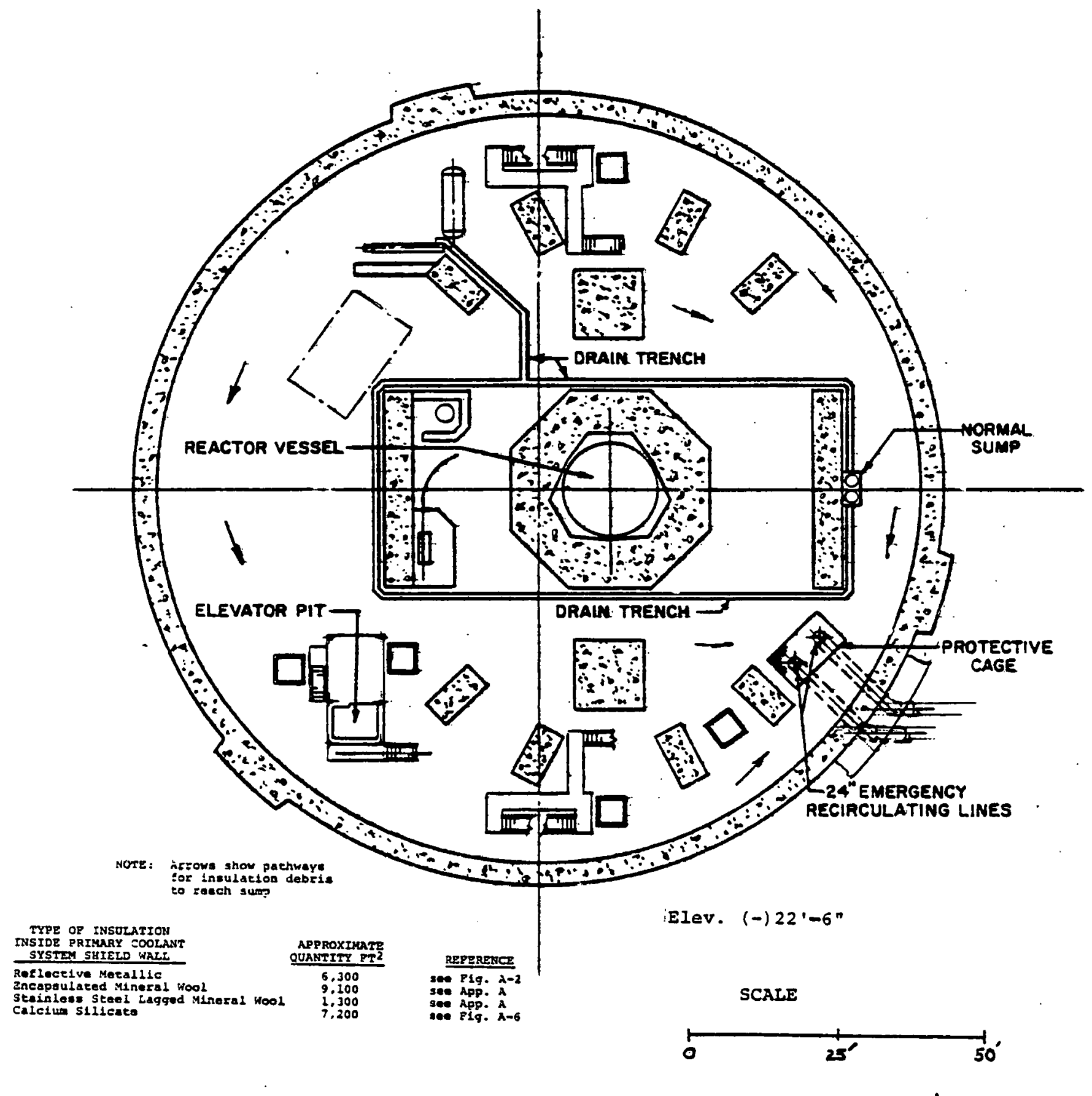

Figure B-2. Reactor Building Plan, Millstone Unit 2 


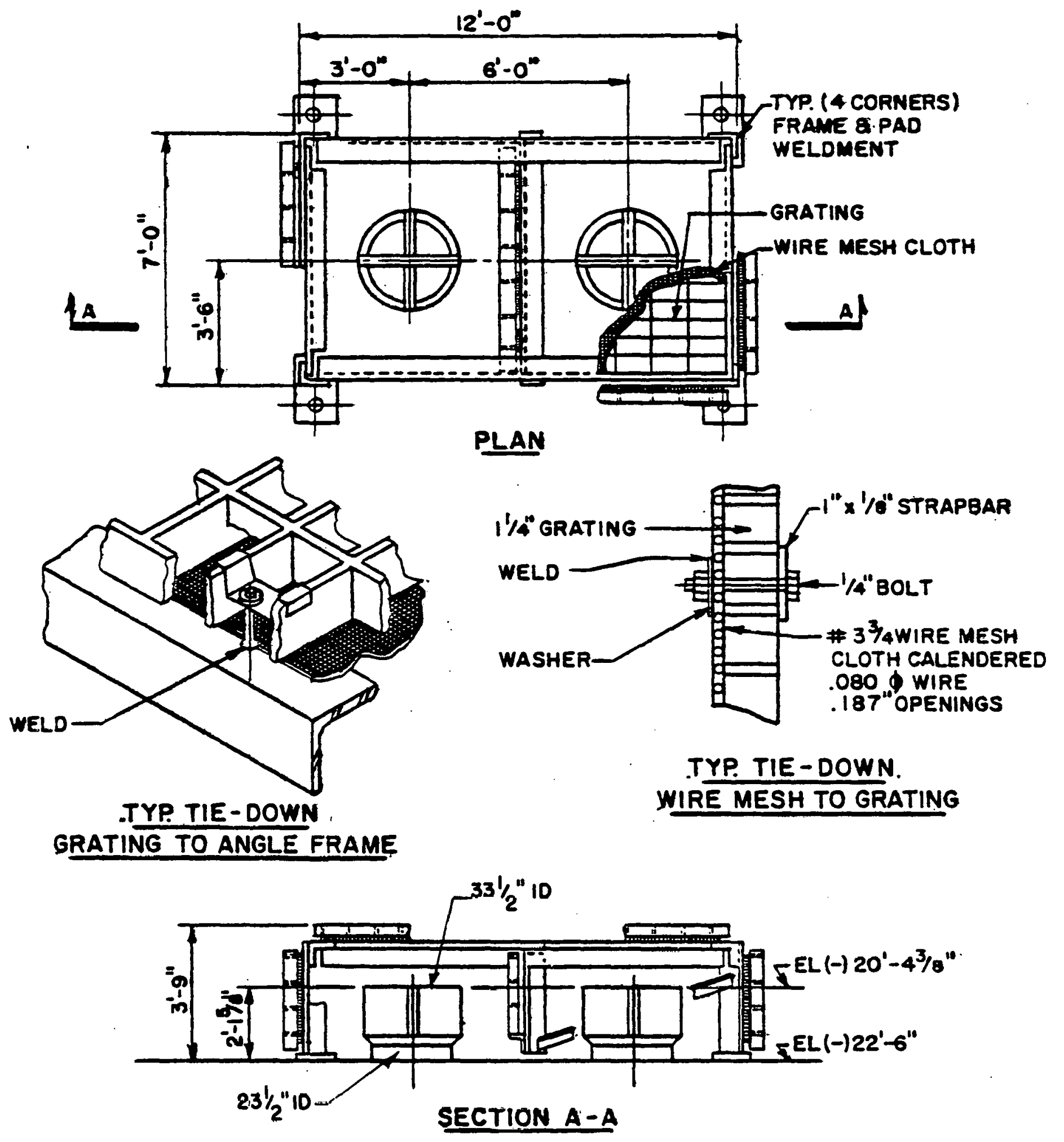

Sump Screen Area $198 \mathrm{ft}^{2}$

Min. Containment Building

Depth after LOCA Elev. 18'-2"

Figure B-3. Containment Sump, Millstone Unit 2 
APPENDIX C

ST. LUCIE NO. 1

PRELIMINARY ASSESSMENT OF

INSULATION DEBRIS GENERATED DURING A

PIPE BREAK EVENT 
A. INTRODUCTION

This report documents the information gathered by Burns and Roe's survey of thermal insulation inside the primary containment of the 777 MWe, Combustion Engineering, PWR St. Lucie No. 1 which started commercial operation in 1975.

The information gathered depicts the following:

1. The arrangement of all piping with in the primary containment including high energy fluid piping

2. The location and configuration of the emergency intake sump for emergency core cooling, and the communicating paths by which debris generated by a major pipe break could reach the emergency recirculating sump

3. Details of the insulation that could be dislodged and become a source of debris as a result of a major break.

Calcium silicate block has been used almost exclusively with in the containment. However, the reactor coolant pump and some removable insulation sections on piping use reflective metallic.

B. LISTING OF INPUT DRAWINGS AND OTHER DOCUMENTS

This section provides a listing of drawings and documents showing details of containment and reactor building, emergency drainage and insulation details for St. Lucie No. 1.

1. Documentation

Letter from 'Florida Power and Light Company to the NRC dated March 16, 1981 on containment sump and insulation information.

2. Drawings

a. Equipment and General Arrangement

$8770-G-065$

8770-G-066

8770-G-067

$8770-G-068$

$8770-6-226$
General Arrangement Reactor Building Floor Plans Sh. 1

General Arrangement Reactor Building Floor Plans Sh. 2

General Arrangement Reactor Building Sections Sh. 1

General Arrangement Reactor Building Sections Sh. 2

Reactor Building Instrument Arrangement Sh. 1 and 2 of 2 


\section{LISTING OF PIPING SYSTEMS INSIDE CONTAINMENT CONTAINING INSULATION}

This section provides a list of systems inside the reactor containment containing insulation. The list includes the system, and the type of insulation used for each system.

System

Safety Injection

Pressurizer Surge Line

Reactor Coolant

Pressurizer Spray Line

Shutdown Cooling

Feedwater

Emergency Feedwater

Pressurizer Safety Relief

Valves to Quench Tank

Main Steam

Equipment Inside

Primary Containment

Reactor Coolant Pumps

Steam Generators

Pressurizer

Reactor Vessel
Type of Insulation

Encapsulated Calcium Silicate Encapsulated Calcium Silicate Encapsulated Calcium Silicate Encapsulated Calcium Silicate Encapsulated Calcium Silicate Encapsulated Calcium Silicate Encapsulated Calcium Silicate Encapsulated Calcium Silicate Encapsulated Calcium Silicate Encapsulated Calcium Silicate

Reflective Metallic Encapsulated Calcium Silicate Encapsulated Calcium Silicate Encapsulated Calcium Silicate

\section{TYPICAL INSULATION DETAILS}

For lines subjected to inservice inspection, the reflective and conventional metal panels which come equipped with buckles for ease of disassembly were used. These lines are insulated with either metal jacketed calcium silicate with removable reflective metal panels at weld joints or metal jacketed calcium silicate with removable conventional panels at weld joints. For the remaining lines, metal jacketed calcium silicate block insulation is used. The block insulation halves are wired together then covered with metal lagging which is riveted or bonded. The steam generators, pressurizer, regenerative heat exchanger and reactor vessel were insulated with metal jacketed calcium silicate with removable reflective metal panels at weld joints.

The reactor coolant pump is insulated with reflective insulation which is fully removable.

E. PIPE BREAK LOCATIONS

None were provided.

F. FSAR REFERENCES ON PERTINENT INSULATION QUESTION

None were provided. 


\section{G. PRELIMINARY INSULATION DEBRIS HAZARDS ANALYSIS}

Figures C-1 and C-2 are simplified sketches of the St. Lucie Unit 1 reactor containment. The reactor vessel, steam generators, pressurizers and associated piping are all located inside the shield wall. The safety injection tanks are located outside the shield wall. The emergency sump is located outside the shield wall in a trench surrounding the shield wall. The location of the emergency sump with in the trench is shown in Figure $\mathrm{C}-2$. Figure $\mathrm{C}-3$ and $\mathrm{C}-4$ show the details of the emergency sump. The trench floor is at El. $12 \mathrm{ft}$. and the sump pit floor is at El. 7'-7". The trench and sump pit are covered by grating at El. 23'. From outside the shield wall a stairway leads down into this trench to a passage through the shield wall and a stairway up to the steam generator cavity floor. Drainage trenches in the cavity pass through the shield wall and drain into the outer trench. These trenches are covered by grating with the outer trench draining into the sump pit. The entrance to the sump pit has a screen door. With in the pit, the two intakes are covered by obelisk screen structure over each individual intake.

For a pipe break outside the shield wall, the potential for a large amount of insulation to migrate towards the sump does not exist. Several floors, either partial or complete, exit outside the shield wall and would catch most of the insulation. However, a small amount of insulation could migrate down the stairwells and other openings.

For a pipe break inside the shield wall, the potential for a large amount of insulation to migrate towards the sump may exist. It may be possible for insulation to pass down through the access stairways and reach both the outer annulus and the outer trench. 


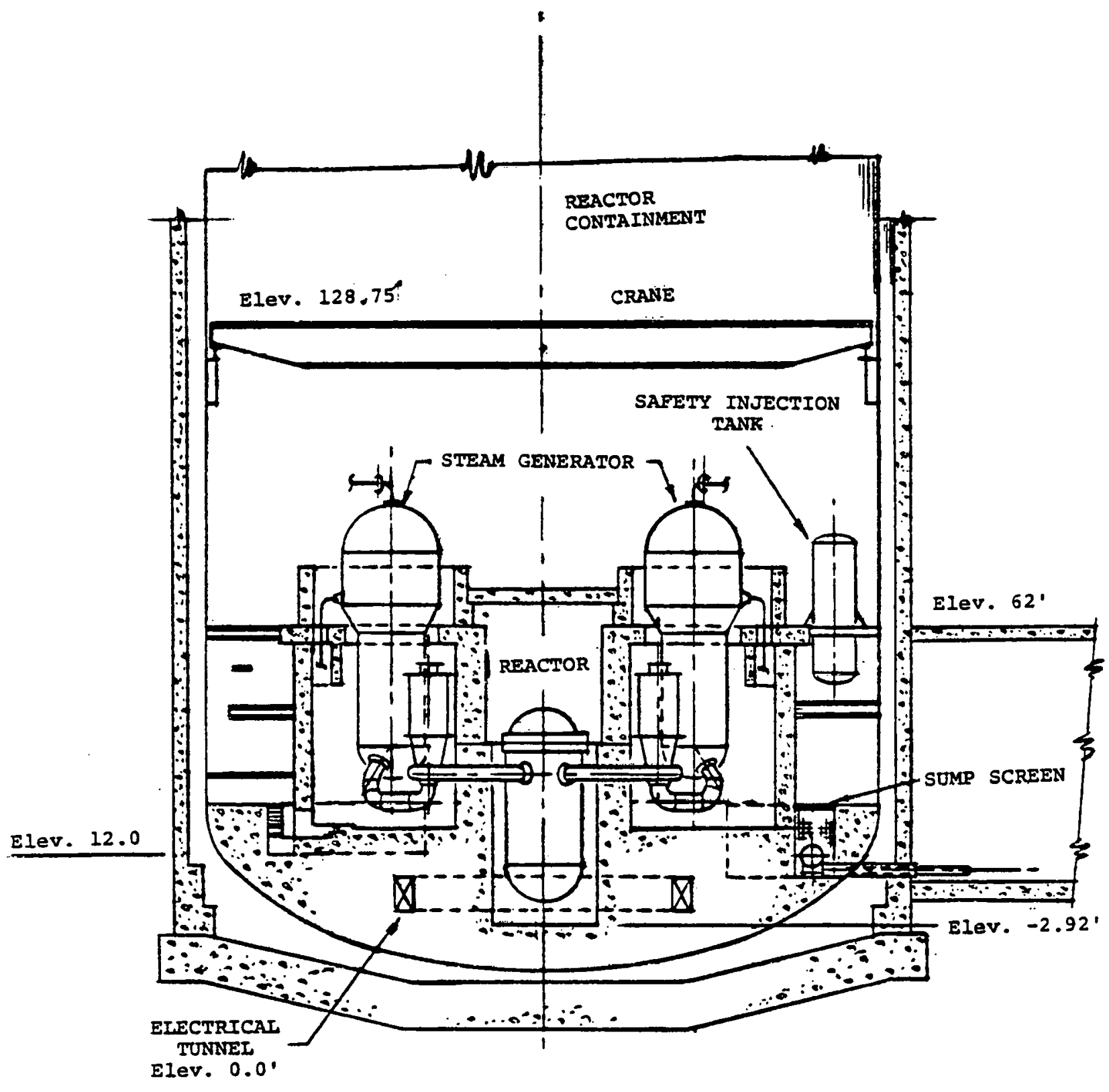

Figure C-1. . Reactor Building Elevation, St. Lucie Unit 1 


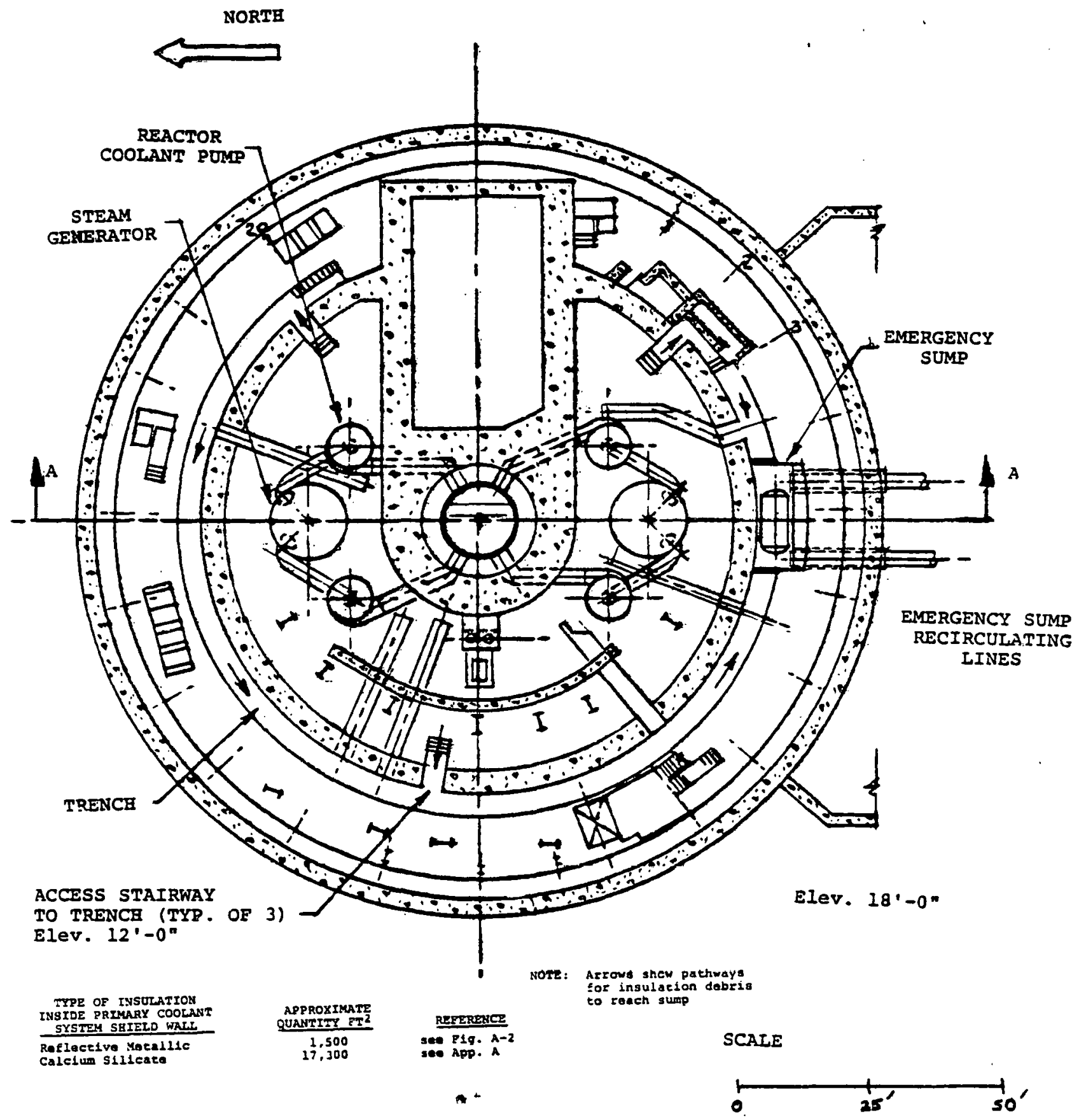

Figure C-2. Reactor Building Plan, St. Lucie Unit 1 


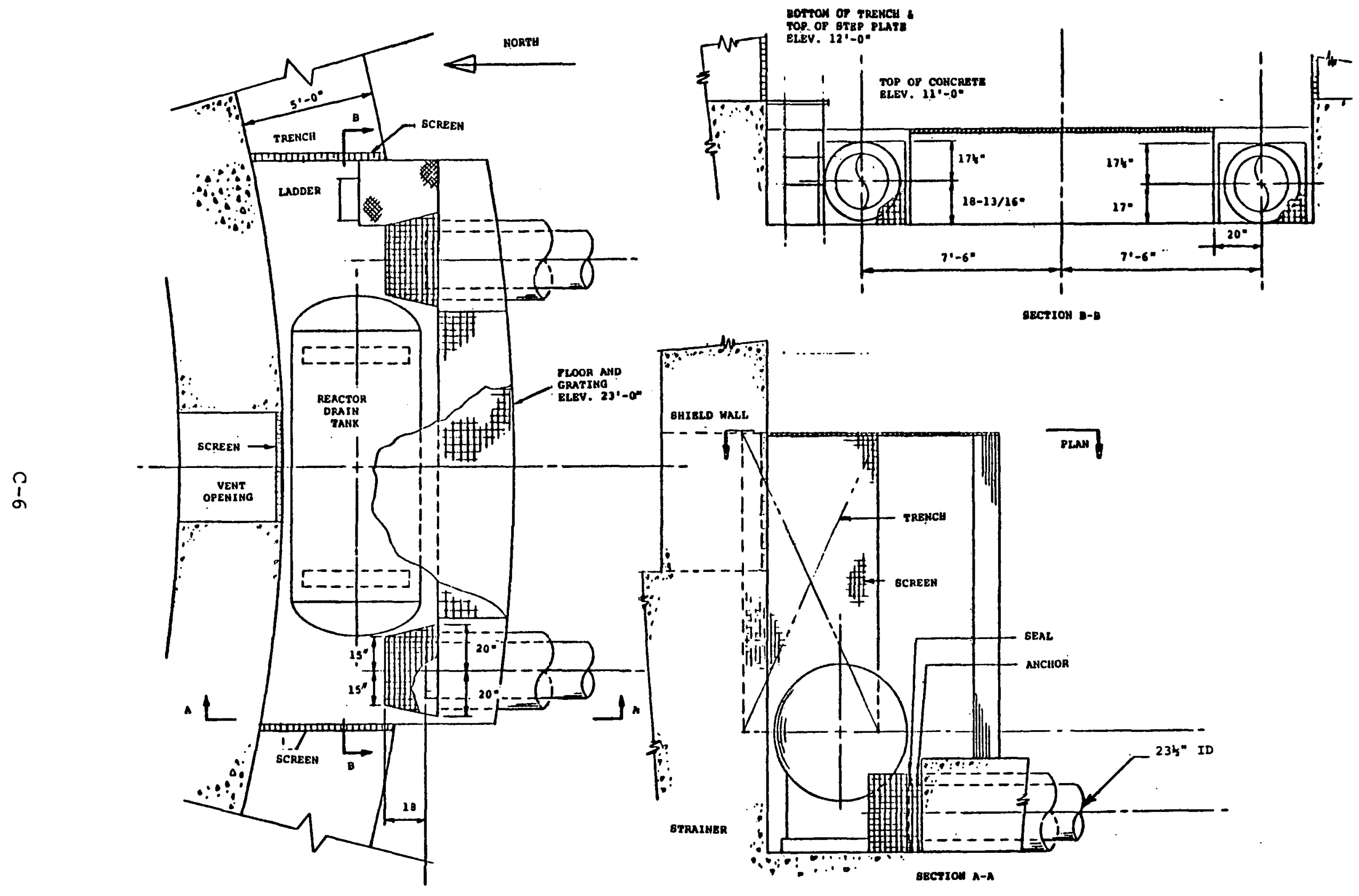

Figure $\mathrm{C}-\mathrm{z}$. Containment sump, St. Lucie Unit 1

Sump Screen Area $266 \mathrm{ft}^{2}$

Min. Containment Building

Water Depth after L Elev 20. 


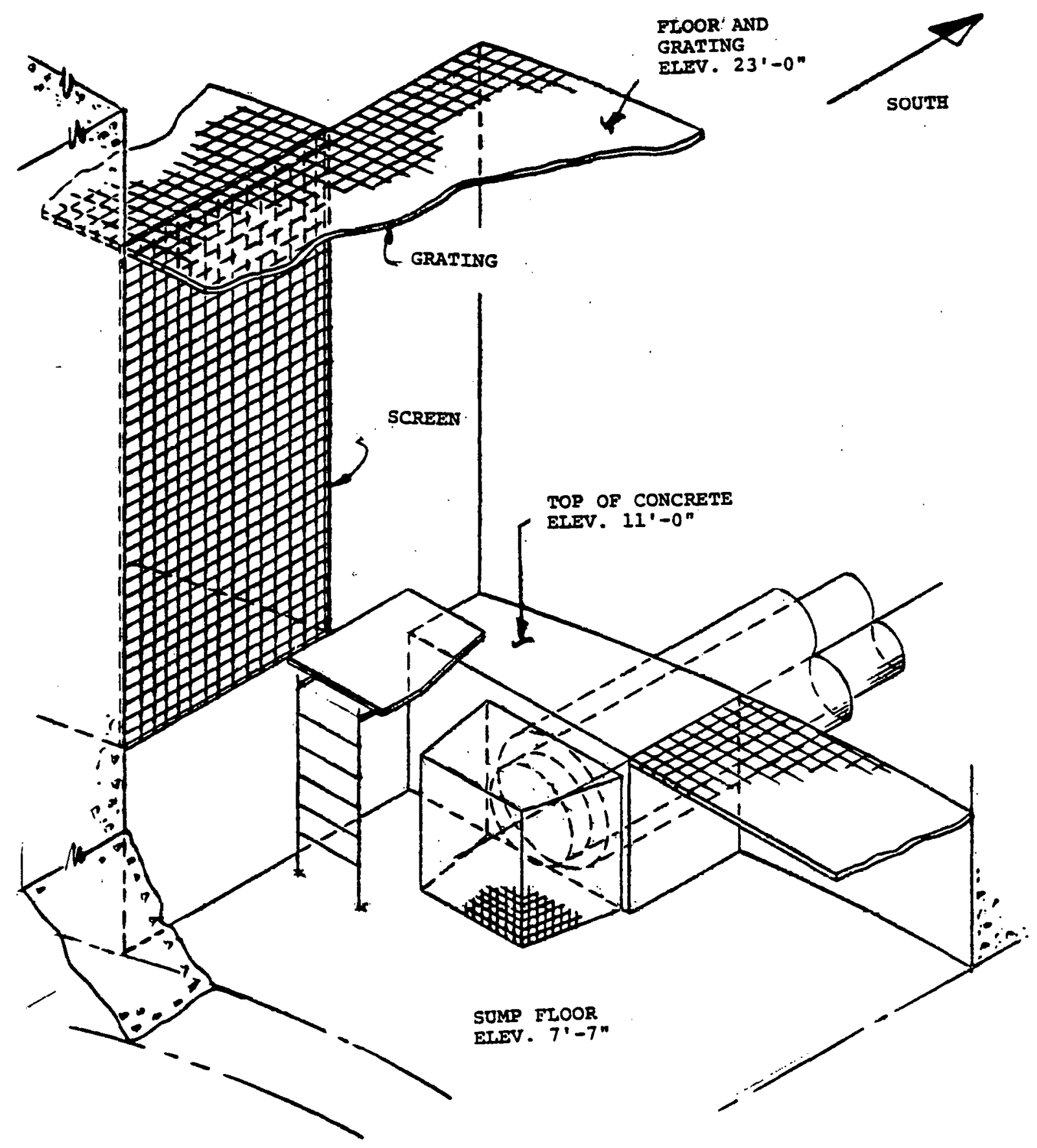

Figure C-4. Containment Sump Isometric, St. Lucie Unit 1 


\section{APPENDIX D}

CALVERT CLIFFS $1 \& 2$

PRELIMINARY ASSESSMENT OF

INSULATION DEBRIS GENERATED DURING A

PIPE BREAK EVENT 


\section{A. INTRODUCTION}

This report documents the information gathered by Burns and Roe's survey of thermal insulation inside the primary containment of the twin 850 MWe, Combustion Engineering, PWR, Calvert $\mathrm{Cl}$ iffs 1 \& 2 which went into commercial operation in 1975 and 1977.

The information gathered depicts the following:

1. The arrangement of all piping within the primary containment including high energy fluid piping

2. The location and configuration of the sump for emergency core cooling, and the communicating paths by which debris generated by a major pipe break could reach the recirculation intake sump

3. Details of the insulation that could be dislodged and become a source of debris as the result of a major break.

Stainless steel, all metal reflective insulation as manufactured by Transco is used for the reactor coolant piping system, reactor vessel, steam generators, and reactor cavity.

Stainless steel encapsulated mineral wool is used on reactor coolant pumps, steam generators, regenerative heat exchanger, and reactor dome. The pressurizer is covered by both reflective metallic and stainless steel encapsulated mineral wool.

\section{B. LISTING OF INPUT DRAWINGS AND OTHER DOCUMENTS}

This section provides a listing of drawings and documents showing details of containment and reactor building, emergency drainage and sump details, piping flow diagrams and equipment general arrangement drawing obtained from Baltimore Gas and Electric.

1. Documentation

a. Letter dated 4/22/81 from BG\&E Principal Engineer 01son to Clark, Chief, Operating Reactors Branch \#3 with attached TABLE 1 Insulated Equipment in Containment

b. Letter dated 3/3/81 from Principal Engineer 01 son to Clark, Chief, Operating Reactors Branch \#3 with attached responses to insulation query including Specification for Plant Insulation - except Reactor Cavity Insulation, Reactor Coolant System and Steam Generators Insulation. Attached are six sheets showing Emergency Sump Location and Details.

c. Transmittal letter dated 7/14/81 from Baltimore Gas \& Electric Engineer Gahan to Riddington B\&R which included 
Containment 1 \& 2 piping drawings, original insulation specifications for high energy piping and systems, M-336, $M-338$, and M-339; along with piping summary sheet.s M-601.

d. Transmittal letter dated 7/15/81 from BG\&E Engineer Gahan to Riddington detailing submitted equipment arrangement drawings in containments 1 \& 2 (17 drawings in al1).

2. Drawings

a. Equipment and General Arrangment Containment

$60-217-E$

$60-215-E$

$60-215-E$

$60-203-E$

$60-204-E$

$60-205-E$

$62-202-E$

62-203-E

62-204-E

$62-205-E$
Equipment Location Containment and Auxiliary Building Unit 1 Section E-E

Equipment Location Containment and Auxiliary Building Unit 1 Section A-A

Equipment Location Containment and Auxiliary Building Plan

El. 5'-0" \& $10^{\prime}-0^{\prime \prime}$

Equipment Location Containment and Auxiliary Building Plan El. 27'-0"

Equipment Location Containment and Auxiliary Building Plan El. 45'-0"

Equipment Location Containment and Auxiliary Building Plan E1. 69'-0"

Equipment Location Containment and Auxiliary Building Unit 2 Plan El. 5'0" \& 10'-0"

Equipment Location Containment and Auxiliary Building Unit 2 Plan El. 27'-0"

Equipment Location Containment and Auxiliary Building Unit 2

Plan E1. 45'-0"

Equipment Location Containment and Auxiliary Building Unit 2 Plan El. 69' -0 " 
$62-217-E$

$62-215-E$

$61-756-E$

$61-757-E$

$61-758-E$

$61-759-E$

$61-760-E$
Equipment Location Containment and Auxiliary Building Unit 2 Section F-F

Equipment Location Containment and Auxiliary Building Unit 1 Section $\mathrm{C}-\mathrm{C}$

Containment Interior Plan 0 El. 10'0" Units 1 \& 2

Containment Interior PIan a E1. 29'-6" Units 1 \& 2

Containment Interior Plan o E1. 37'-4" Units $1 \& 2$

Containment Interior Plan 0 El. 45'-0" Units $1 \& 2$

Containment Interior $\mathrm{P} 1$ an $\mathrm{C}$ E1. 69'-0" Units 1 \& 2

b. Emergency Sump Design Details

Selected sump design details selected photo copied sections of the following drawings:

Bechte1 Drawings Nos.

M-132 Rev. 9

M-137 Rev. 9

M-136 Rev. 5

C-256 Rev. 8 ( 2 sheets)

M-565 Rev. 5

c. Flow Diagrams for Insulated Systems in Containment None were provided.

d. Piping Layout Drawings $60-E 463-E$ Area No. 23 Piping Plan El. 69'-0"

$60-462-E$ Area No. 23 Piping Plan E1. $45^{\prime}-0^{\prime \prime}$ 


$$
\begin{aligned}
& 60-461-E \\
& 60-460-E \\
& 60-457-E \\
& 60-456-E \\
& 60-455-E \\
& 60-454-E \\
& 60-453-E \\
& 60-452-E \\
& 60-451-E \\
& \text { 60-450-E } \\
& 60-463-E \\
& 60-462-E \\
& 60-461-E \\
& 60-460-E \\
& 60-457-E \\
& 60-456-E \\
& 60-455-E \\
& 60-454-E \\
& 60-453-E \\
& \text { Area No. } 23 \text { Piping Plan } \\
& \text { E1. 27'-0" } \\
& \text { Area No. } 23 \text { Piping Plan } \\
& \text { El. 10' }-0^{\prime \prime} \\
& \text { Area No. } 22 \text { and } 23 \text { Piping } \\
& \text { Sections and Details } \\
& \text { Area No. } 22 \text { and } 23 \text { Piping } \\
& \text { Sections and Details } \\
& \text { Area No. } 22 \text { and } 23 \text { Section "B-B" } \\
& \text { Area No. } 22 \text { and } 23 \text { Section "A-A" } \\
& \text { Area No. } 22 \text { and } 23 \text { Piping } \mathrm{Pl} \text { an } \\
& \text { El. } 69^{\prime}-0^{\prime \prime} \\
& \text { Area No. } 22 \text { Piping Plan El. 45'-0" } \\
& \text { Area No. } 22 \text { Piping Plan El. 27'-0" } \\
& \text { Area No. } 22 \text { Piping PIan El. 10'-0" } \\
& \text { Area No. } 25 \text { Piping Plan } \\
& \text { E1. 69'-0" } \\
& \text { Area No. } 25 \text { Piping Plan } \\
& \text { El. } 45^{\prime}-0^{\prime \prime} \\
& \text { Area No. } 25 \text { Piping Plan } \\
& \text { El. 27' }-0^{\prime \prime} \\
& \text { Area No. } 25 \text { Piping Plan } \\
& \text { E1. 10'0" } \\
& \text { Area No. } 24 \text { and } 25 \text { Piping } \\
& \text { Sections and Details } \\
& \text { Area No. } 24 \text { and } 25 \text { Piping } \\
& \text { Sections and Details } \\
& \text { Area No. } 24 \text { and } 25 \text { Piping Section } \\
& \text { "B-B" } \\
& \text { Area No. } 24 \text { and } 25 \text { Piping Section } \\
& \text { "Ä-A" } \\
& \text { Area No. } 24 \text { Piping Plan } \\
& \text { El. 69'0" }
\end{aligned}
$$


$60-452-E$

$60-451-E$

$60-450-E$
Area No. 24 Piping Plan

E1. $45^{\prime}-0^{\prime \prime}$

Area No. 24 Piping Plan

El. $27^{\prime}-0^{\prime \prime}$

Area No. 24 Piping Plan

E1. $10^{\prime}-0^{\prime \prime}$

e. Insulation Drawings

None submitted.

c. LISTING OF PIPING SYSTEMS INSIDE CONTAINMENT CONTAINING INSULATION

This section provides a list of systems inside the reactor containment containing insulation. The list includes the system, nominal pipe sizes inside containment, and the type of insulation used for each system.

System

Pressurizer Surge Line

Coolant Loops

Letdown Line

Safety Injection

Charging

RCS Auxiliary Piping

RCS Vents \& Drains

Pressurizer Spray

Reactor Coolant Pump

Bleed

Shutdown Cooling

RCS Pressure End

Equipment Inside/

Primary Containment

Reactor Coolant Pumps

Steam Generators

Regenerative Heat Exchanger

Pressurizer

Reactor Vessel

Reactor Dome

Reactor Cavity
Nominal Pipe Type of

Size (inches) Insulation

12-3/4 Reflective

49-3/4,35-1/4 Reflective

$\begin{aligned} 2 & \text { Encapsulated } \\ 12,6 & \text { Encapsulated }\end{aligned}$

Encapsulated

Encapsul ated

Encapsulated

Encapsulated

Encapsulated

12

$3 / 4$
Mineral Wool

Mineral Wool
Encapsulated
Reflective,
Encapsulated
Encapsulated
Reflective,
Encapsulated
Reflective
Encapsulated
Reflective 


\section{TYPICAL INSULATION DETAILS}

Reflective metallic insulation is used exclusively for the reactor cavity reactor vessel and primary coolant loops. The insulation used for piping is typically two feet or longer in length, 3-4 inches thick and split in two sections with each section covering half the pipe. These sections have 24 gauge stainless steel outer sheets which enclose nine or ten $2 \mathrm{mil}$ stainless steel foil sheets. The inner sheets are built up about three sheets per inch of insulation with the innermost sheet enclosing the foil 22 gauge stainless steel. End closures are 26 gauge stainless steel.

Reflective panels generally consist of 22 gauge stainless steel 9 or 10 sheets on $2 \mathrm{mil}$ stainless steel foil and outer sheet of 24 gauge stainless steel. Most panels are reinforced using a stainless steel nail fixed through the section.

Insulation panels and sections are attached to equipment insulation support frames or angles and to piping using combinations of $\mathrm{C}$ clips, Z-clips, interlapping panels, and quick release buckles. Some reactor vessel insulation is permanently attached using self tapping screws.

Mineral wool panels, which are used exclusively or in combination with reflective metallic on reactor coolant pumps, steam generators, regenerative heat exchangers, pressurizer, reactor dome, and all nonprimary coolant piping, are of similar outer construction to reflective metallic. The panels consist of 22 gauge stainless steel sheet, a thickness of 9 pound density mineral wool, and a 24 gauge stainless steel sheet. End closures are 26 gauge stainless steel. There is some variation in gauge of stainless steel sheeting used to enclose the mineral wool panel on the reactor dome, 18 and 22 gauge stainless steel is used. Also variation in density thickness is possible.

Mineral wool panels are attached in the same manner as that outlined for the reflective metallic.

\section{E. PIPE BREAK LOCATIIONS}

Not developed for Calvert Cliffs Unit No. 1 \& 2 .

F. FSAR REFERENCES ON PERTINENT INSULATION QUESTIONS

None were submitted by Baltimore Gas and Electric.

\section{G. PRELIMINARY INSULATION DEBRIS HAZARD ANALYSIS}

Figures D-1 and D-2 are simplified sketches of the Calvert Cliffs Unit No. 1 Reactor Containment Building. The reactor vessel, steam generators, reactor coolant pumps, pressurizer, and associated piping are located inside the shield wall. Figure D-2 shows the location of the emergency sump on floor of the containment building at an eleva- 
tion of 11'. Figure $D-3$ shows the details of the emergency sump. The sump adjoins the reactor building sump and the two sumps are separated by a 1/4" thick steel plate with $1 / 2$ inch diameter holes drilled in the bottom. The screen surrounding the sump is constructed with beams and covered with stainless steel grating. Clipped to the inside of the grating is a $2-3 / 4$ " mesh stainless steel wire cloth, .120 inch diameter.

For a pipe break inside the shield wall, the potential for a large amount of insulation to migrate towards the sump is very small. A concrete and grate floor exists at El. 31' and would catch most of the insulation. Similarly, for a pipe break outside the shield wall, the potential problem is small. A floor existing at El. 45' would catch most of the insulation. However, a small amount of insulation could migrate down the stairwells and other openings.

For a pipe break inside the shield wall below the floor at El. $31^{\prime}$ or outside the shield wall below the floor at El. 45', insulation can migrate to the sump. The sump has some small diameter ( 2 to 4 inches) pipe passing over it. Insulation from this pipe could fall onto the sump. The reflective metallic would sink to the floor while the encapsulated mineral wool would float and then sink after it became saturated with water. 


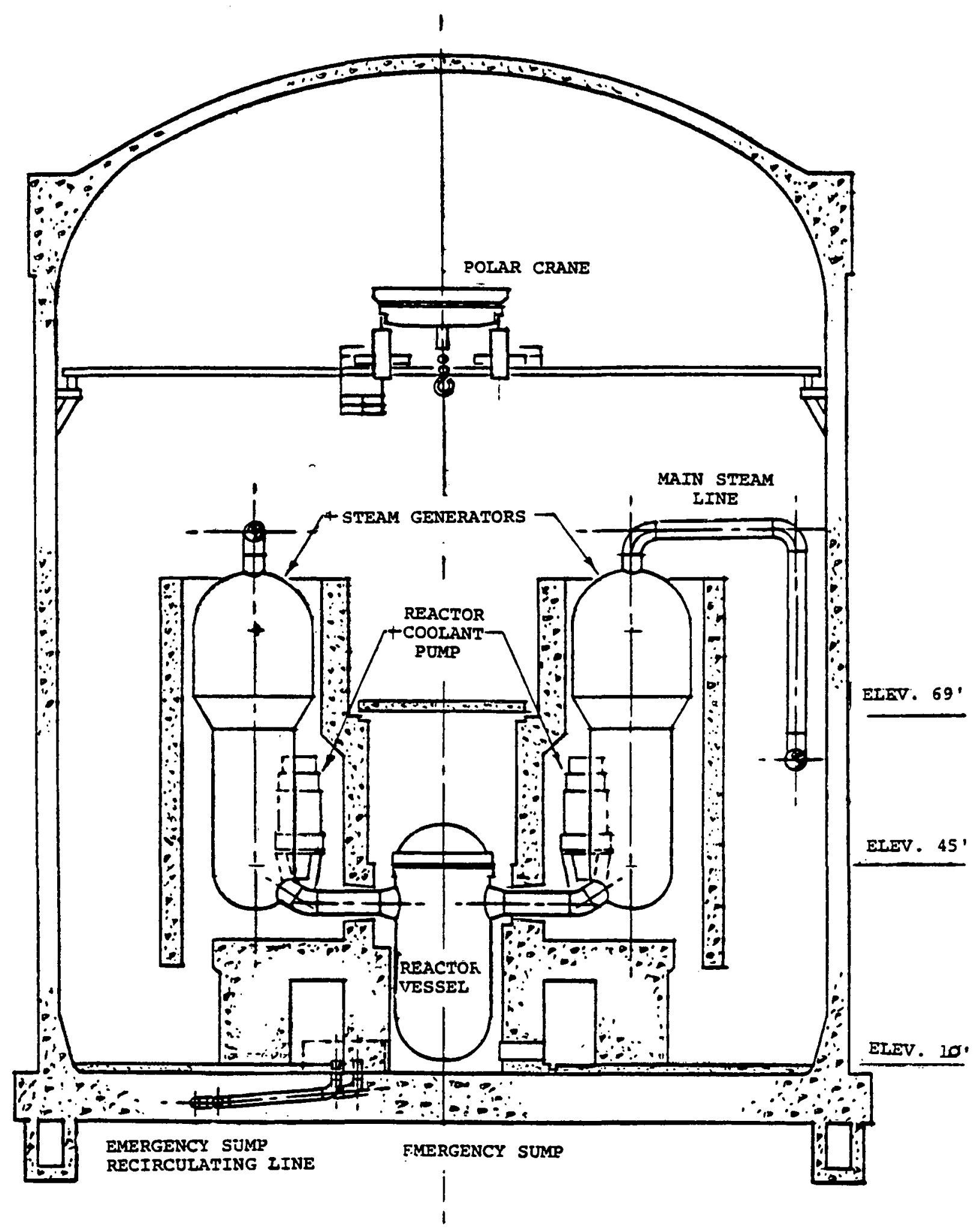

Figure D-1. Reactor Building Elevation, Calvert Cliffs, Units 1 and 2 


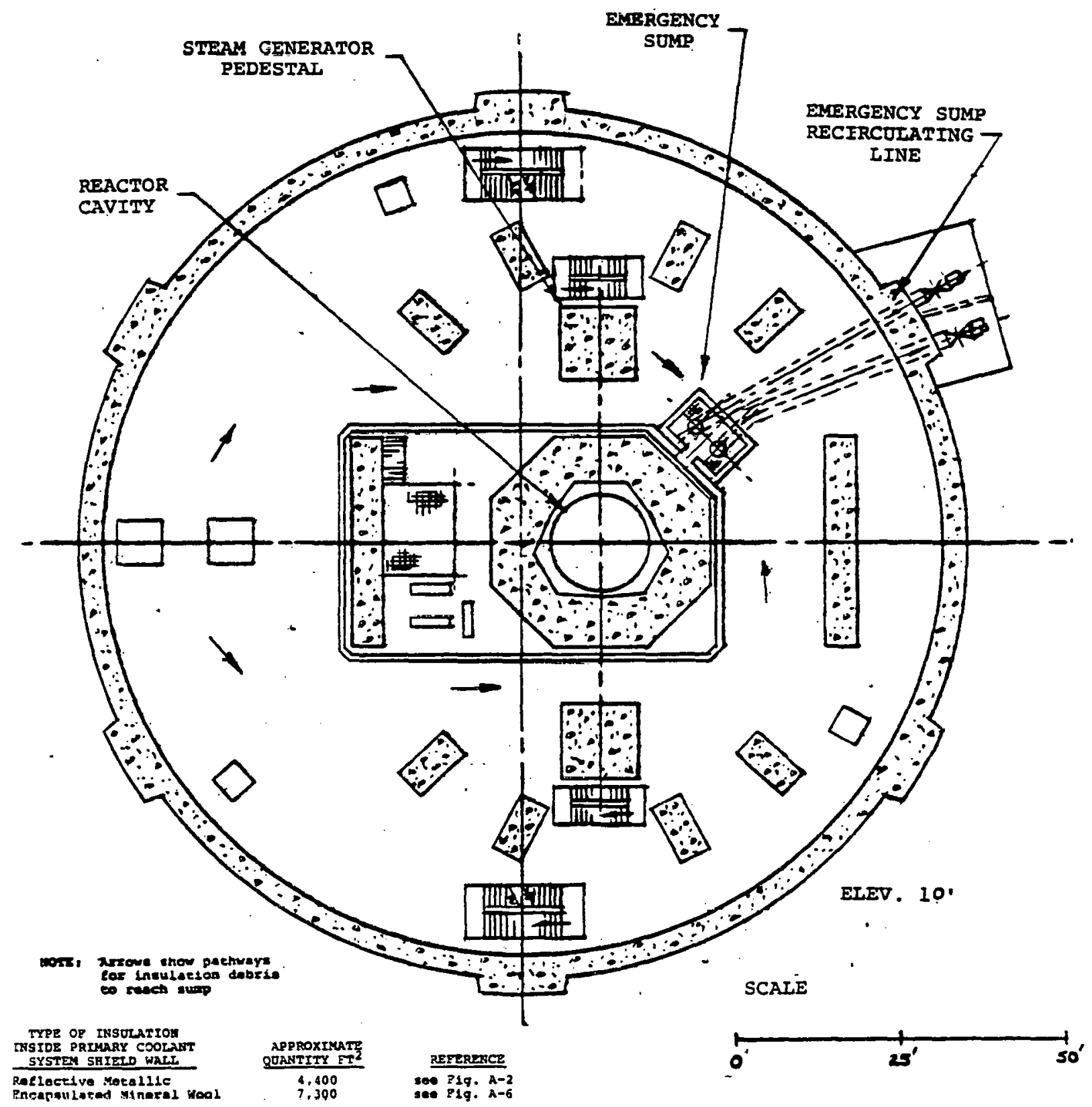

Figure D-2. Reactor Building Plan, Calvert Cliffs, Units 1 and 2 


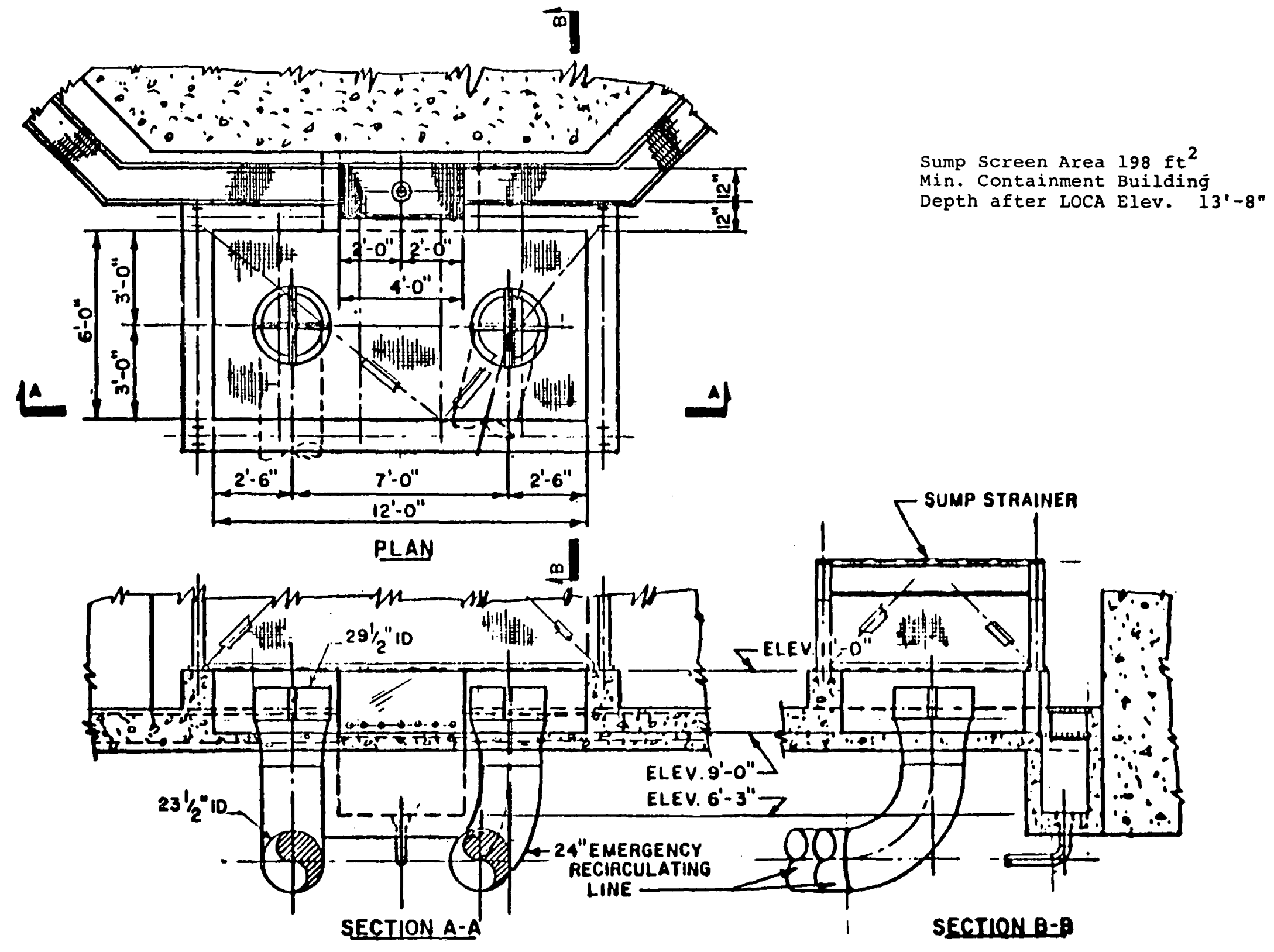

Figure D-3. Containment Sump,

Calvert Cliffs Units 1 and 2 
APPENDIX E

ROBERT EMMETT GINNA UNIT 1

PRELIMINARY ASSESSMENT OF

INSULATION DEBRIS GENERATED DURING A

PIPE BREAK EVENT 


\section{A. INTRODUCTION}

This report documents the information gathered by Burns and Roe's survey of thermal insulation inside the primary containment of the 490 MWe Westinghouse PWR, Robert Emmett Ginna Nuclear Power Plant, Unit No. 1 which commenced commercial operation in 1969.

The information gathered depicts the following:

1. The arrangement of all piping with in the primary containment building including high energy fluid piping

2. The location and configuration of the sump for emergency core cooling, and the communication paths by which debris generated by a major pipe break could reach the emergency recirculation sump

3. Details of the insulation that could be dislodged and become a source of debris as a result of a major pipe break.

According to information supplied by Rochester Gas and Electric Corp. (RG\&E), Kaylo (hydrous calcium silicate) and Kaylo-20, manufactured by Johns-Manville, are used to insulate most of the piping system in containment. Vinycel, also manufactured by Johns-Manville, is used to insulate the interior of the containment building wall and all equipment insulated inside containment is insulated with Johns-Manville Kaylo block and bonding cement.

\section{B. LISTING OF INPUT DRAWINGS AND OTHER DOCUMENTS}

This section provides a listing of drawings and documents showing details of the reactor building's piping system, equipment, and insulation.

1. Documentation

a. Docket No. 50244. Letter dated March 4, 1981 from John E. Maier, Vice President, RG\&E to Mr. Denn is M. Crutchfield, Chief Operating Reactors Branch No. 5, NRC, titled Information Request Regarding Containment Sumps and Insulation for Operating Reactors.

2. Drawings

a. General Arrangement - Reactor Containment

$$
\begin{array}{ll}
\text { D-001-012 } & \text { Plan Above Basement Floor } \\
\text { D-421-001 } & \text { Reactor Containment Vesse 1, Mat } \\
& \text { Foundation, Elev. 233'-8" and Ring } \\
& \text { Girder }
\end{array}
$$


D-421-003

D-421-009

b. Emergency Sump Design Details

D-421-002

Reactor Containment Vessel, Mat

Foundation, Elev. 233'-8",

Reinforcement and Details

c. Piping Diagrams for Inside Containment

D-304-014

D-304-083

D-304-084

D-304-122

D-304-193

D-304-601

D-304-602

D-304-603

D-304-604

D-304-611

D-304-612

D-304-613

D-304-614

$D-304-618$
Reactor Containment Vessel, Basement Floor Slab Elev. 235'-8"

Reactor Containment Vessel, Basement Floor Dowel and Anchor Bolt Location 


\begin{tabular}{|c|c|}
\hline D-304-619 & $\begin{array}{l}\text { Sections, R.V. Support Clg. \& R.C. } \\
\text { Pump Coolant }\end{array}$ \\
\hline$D-304-630$ & $\begin{array}{l}\text { Plan \& Sections, Misc. Above Elev. } \\
253^{\prime}-0^{\prime \prime} \text { Inside Containment }\end{array}$ \\
\hline$D-304-631$ & $\begin{array}{l}\text { Chemical and Volume Control System - } \\
\text { Misc. Plan }\end{array}$ \\
\hline$D-304-632$ & $\begin{array}{l}\text { Chemical and Volume Control System - } \\
\text { Misc. Sections }\end{array}$ \\
\hline$D-304-641$ & $\begin{array}{l}\text { Containment Spray, Plan \& Sections } \\
\text { Above } 274^{\prime}-6^{\prime \prime} \& 278^{\prime}-4^{\prime \prime}\end{array}$ \\
\hline$D-304-642$ & $\begin{array}{l}\text { Safety Injection \& Containment Spray } \\
\text { Plan Below Elev. } 274^{\prime}-6^{\prime \prime} \& \text { Elev. } \\
278^{\prime}-4^{\prime \prime}\end{array}$ \\
\hline D-304-643 & $\begin{array}{l}\text { Safety Injection \& Containment Spray } \\
\text { Sections }\end{array}$ \\
\hline$D-304-645$ & $\begin{array}{l}\text { Safety Injection System Plan \& Misc. } \\
\text { Sections }\end{array}$ \\
\hline B-326-004 & $\begin{array}{l}\text { Piping Detai1, 8" Suction Line From } \\
\text { Containment Sump "B" to Residual Heat } \\
\text { Pumps, 4' Reactor Drain Pump Suction }\end{array}$ \\
\hline
\end{tabular}

d. Insulation Drawings

None were provided.

e. Reactor Building Platform Drawings

None were provided.

c. LISTING OF PIPING INSIDE CONTAINMENT CONTAINING INSULATION

This section provides a list of piping systems and equipment inside primary containment containing insulation. The list includes the system, equipment, nnminal pipe sizes, and type of insulation used for each system. The relationship between systems and equipment, and insulation were figured based on information provided the NRC. 
System

Safety Injection

Pressurizer Surge Line

Reactor Coolant System

Pressurizer Spray Line

Shutdown Cooling

Feedwater

Emergency Feedwater

Pressurizer Safety Relief

Valves to Quench Tank

Main Steam

Chilled Water

Equipment Inside

Primary Containment

Reactor Vessel

Reactor Coolant Pump

Pressurizer

CVCS Regenerative

Heat Exchanger

Steam Generator
Nominal Pipe Type of

Size (inches) Insulation

$4,6,10$

6

29,31

3

6,10

14

4

8

30

$2,1,1-1 / 2$
Calcium Silicate

Calcium Silicate

Calcium Silicate

Calcium Silicate

Calcium Silicate

Calcium Silicate

Calcium Silicate

Blanket

Calcium Silicate

Fiberglass

\section{TYPICAL INSULATION DETAILS}

The containment building walls are insulated with Johns-Manville Vinycel insulation sheets measuring $44^{\prime \prime} \times 84^{\prime \prime} \times 1-1 / 4 "$. Each sheet is covered with 019 ga. type 304 stainless steel.

The piping system inside containment is mostly insulated with Johns-Manville Kaylo (hydrous calcium silicate) and Kaylo-20 with densities of 11 and $12 \mathrm{lb} / \mathrm{ft} 3$, respectively. Also used in insulating the system was Johns-Manville's thermobestos and Pittsburgh-Corning's Unibestos both of which are currently being replaced by Johns-Manville's Thermo-12 (hydrous calcium silicate). The density of Thermo-12 is $13 \mathrm{lb} / \mathrm{ft} 3$.

At points in piping runs where insulation is anticipated to be occasionally removed, insulation blankets were used. Blankets that were installed were Eastern Refractories Company, Inc. Erco Mat. (ceramic glass fiber) of $15 \mathrm{lb} / \mathrm{ft} 3$, Clairmont Supply Co., Claremat 1200 (mechanically bonded glass fiber) of $15 \mathrm{lb} / \mathrm{ft} 3$, and $\mathrm{J}$. P. Stevan's Tent-Mat. A small amount of Johns-Manville's Micro-Lok 650 (fiber glass) was installed on the service water piping to the reactor compartment cooling system. 
All the insulation on the piping system is attached with stainless steel wire. Mineral fiber bonding cements have been used inside containment on valves and other irregular shaped components requiring insulation. All piping insulation, except the Micro-Lok 650 , is jacketed with .010" ga 304 stainless steel and seams are popriveted. All equipment insulated inside containment is insulated with Johns-Manville Kaylo block and bonding cement and is jacketed with .020" ga stainless steel.

\section{E. PIPE BREAK LOCATIONS}

Not developed for R. E. Ginna Unit No. 1 .

\section{F. FSAR REFERENCES ON PERTINENT INSULATION QUESTIONS}

None were submitted by Rochester Gas and Electric.

\section{G. PRELIMINARY INSULATION DEBRIS HAZARD ANALYSIS}

Figures $E-1$ and $E-2$ are simplified sketches of the Robert $E$. Ginna reactor containment. The reactor vessel, steam generators, pressurizer, and associated piping are all located inside the shield wall. The location of the emergency sump just below part of the shield wall and the reactor refueling channel at El. 235'-8" is shown in Figure E-2. Figure E-3 shows the details of the emergency intake sump. The sump in plain view is a trapezoidal opening in the floor covered stainless steel grating. The tank and two intake pipes within the $8-1 / 2^{\prime}$ deep sump are separated by a $1-1 / 2^{\prime \prime}$ grating.

For a pipe break outside the shield wall, the potential for a large amount of insulation to migrate towards the sump does not exist.

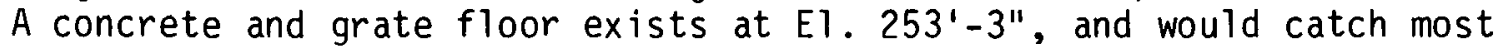
of the insulation. However, a small amount of insulation could migrate down the stairwells and other openings.

For a pipe break inside the shield wall, the potential for a large amount of insulation to migrate towards the sump is greater than the outside case. There exists a number of platforms with in the region which would catch some of the insulation before it reaches the containment floor. Once on the basement floor level, the calcium silicate will float while the asbestos and glass fiber blanket will also initially float. This insulation could be transported to the emergency sump, and the calcium silicate and glass fiber blanket could sink at the sump.

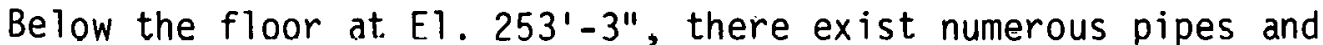
equipment in the immediate vicinity of the sump. The largest item in this region is the pressurizer relief tank. A pipe break in the region could result in large quantities of insulation around the sump. 


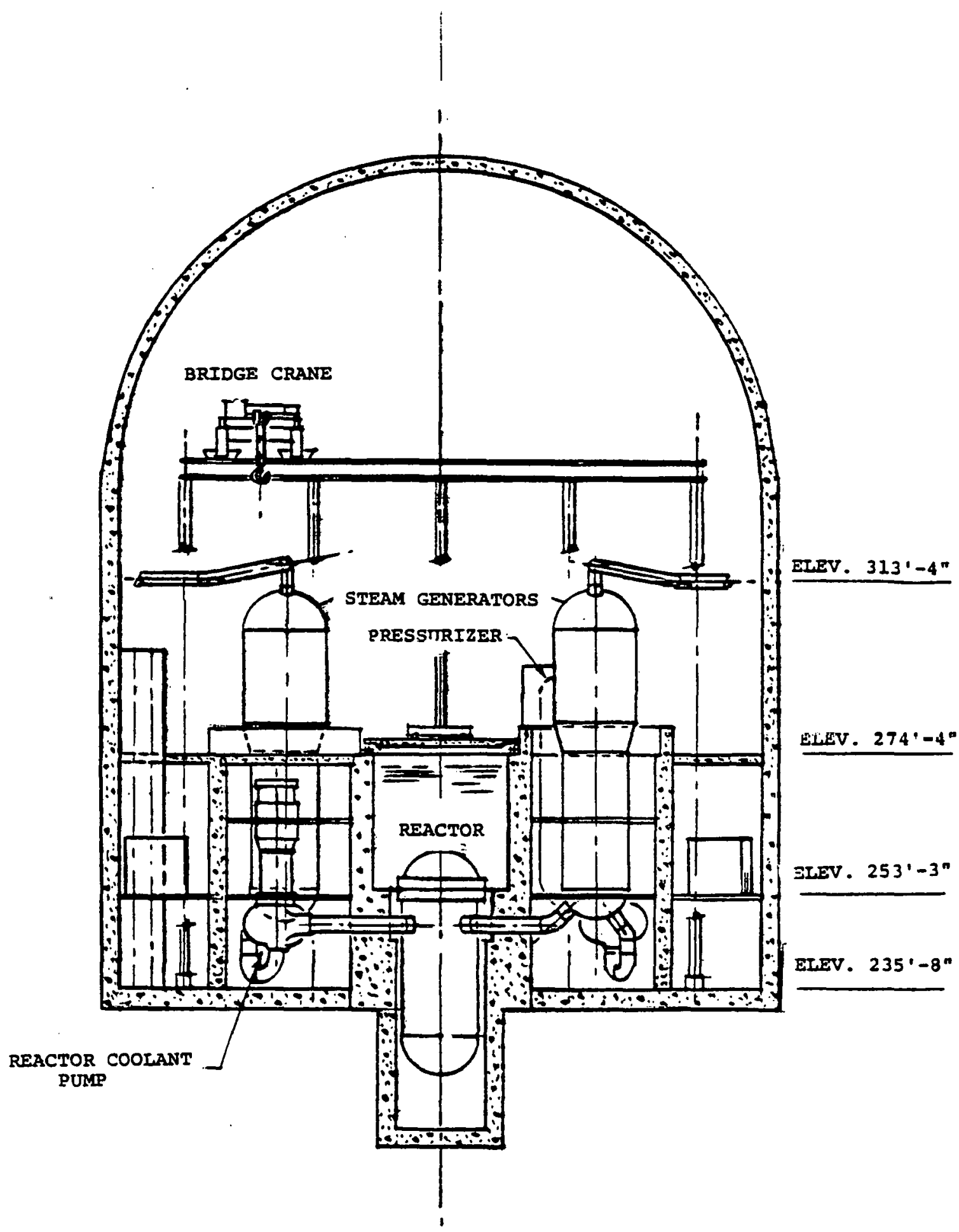

Figure E-1. Reactor Building Elevation, Robert E. Ginna 


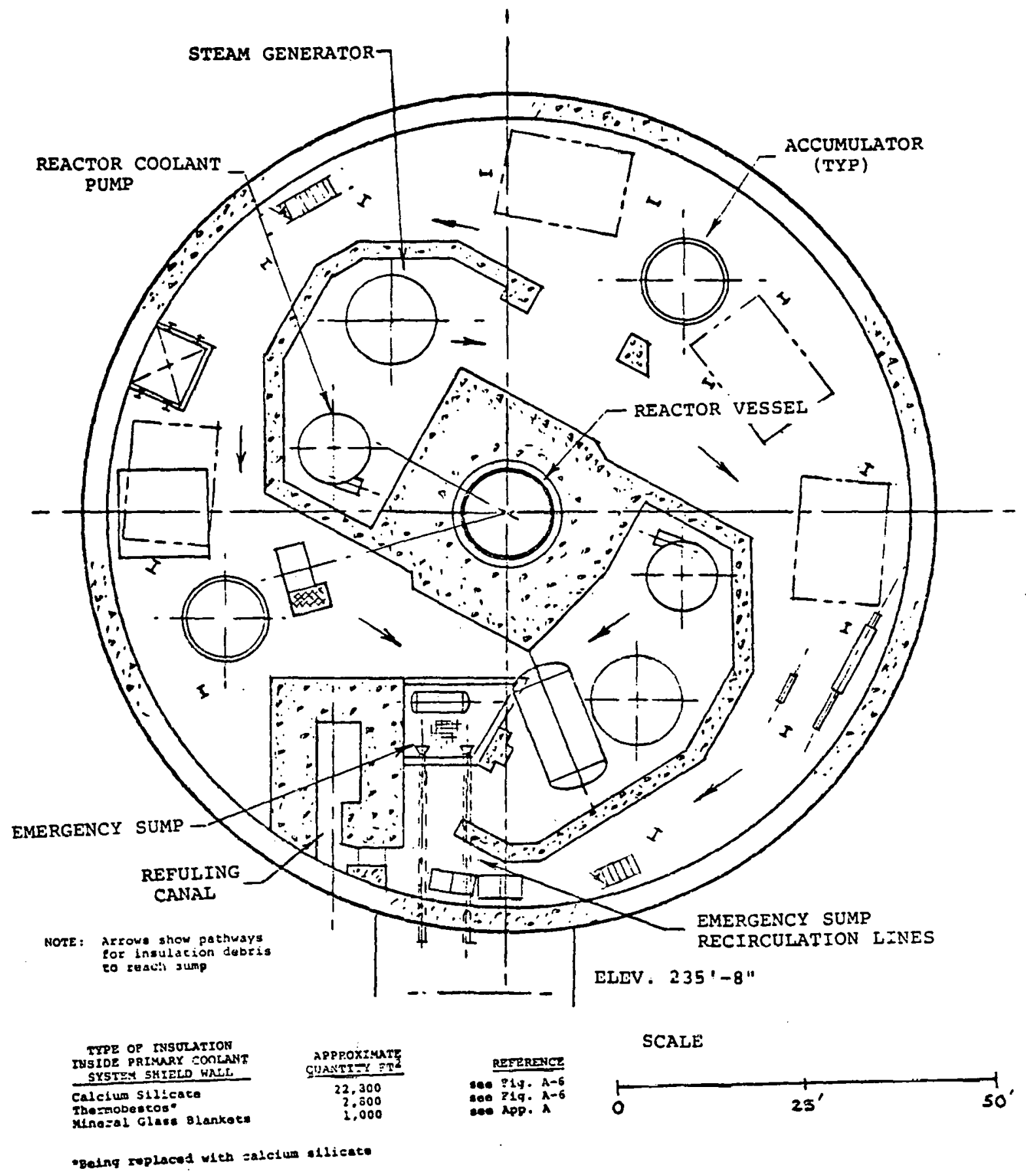

Figure E-2. Reactor Building Plan, Robert E. Ginna 


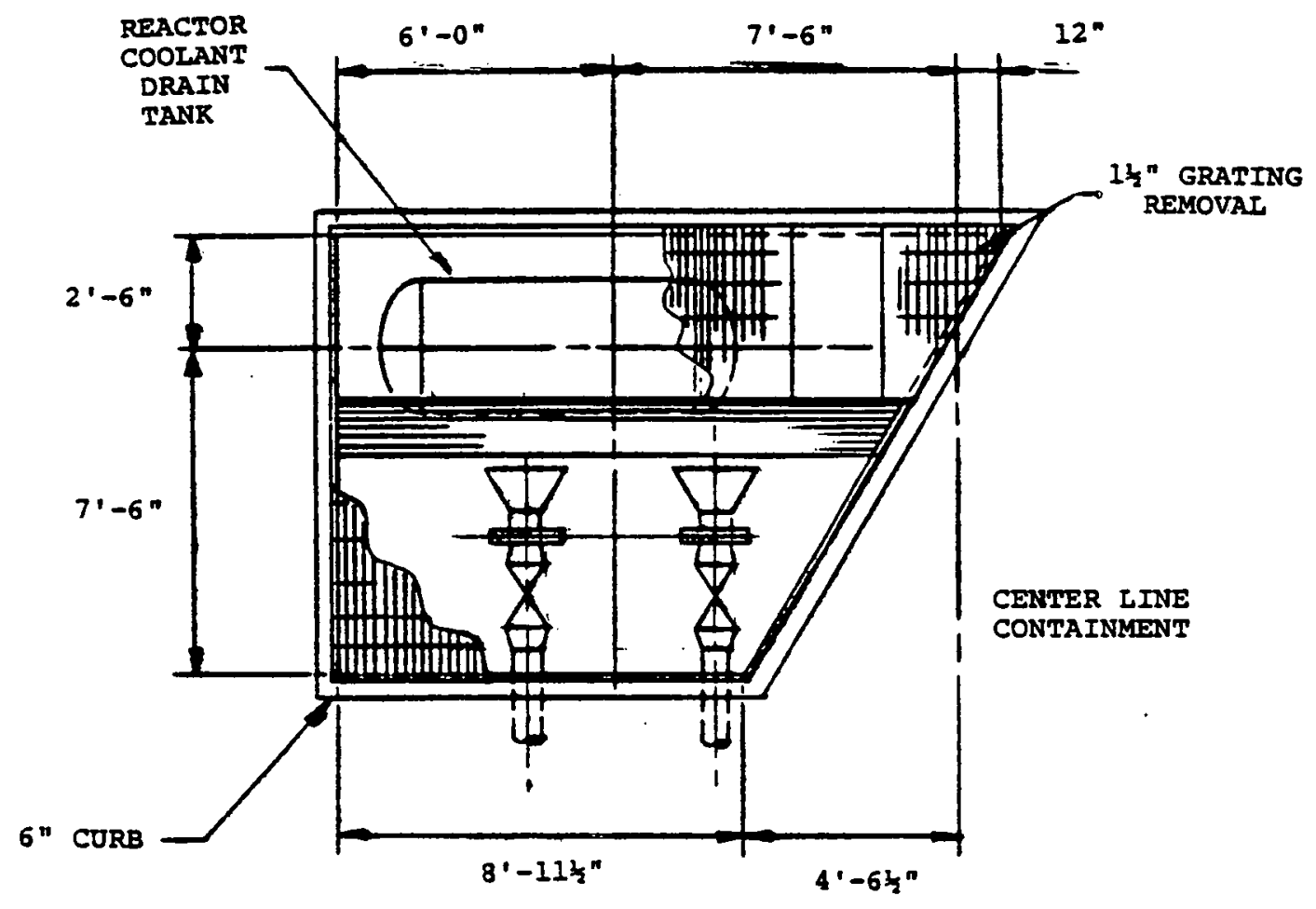

Sump Screen Area $142 \mathrm{ft}^{2}$

Min. Containment Building

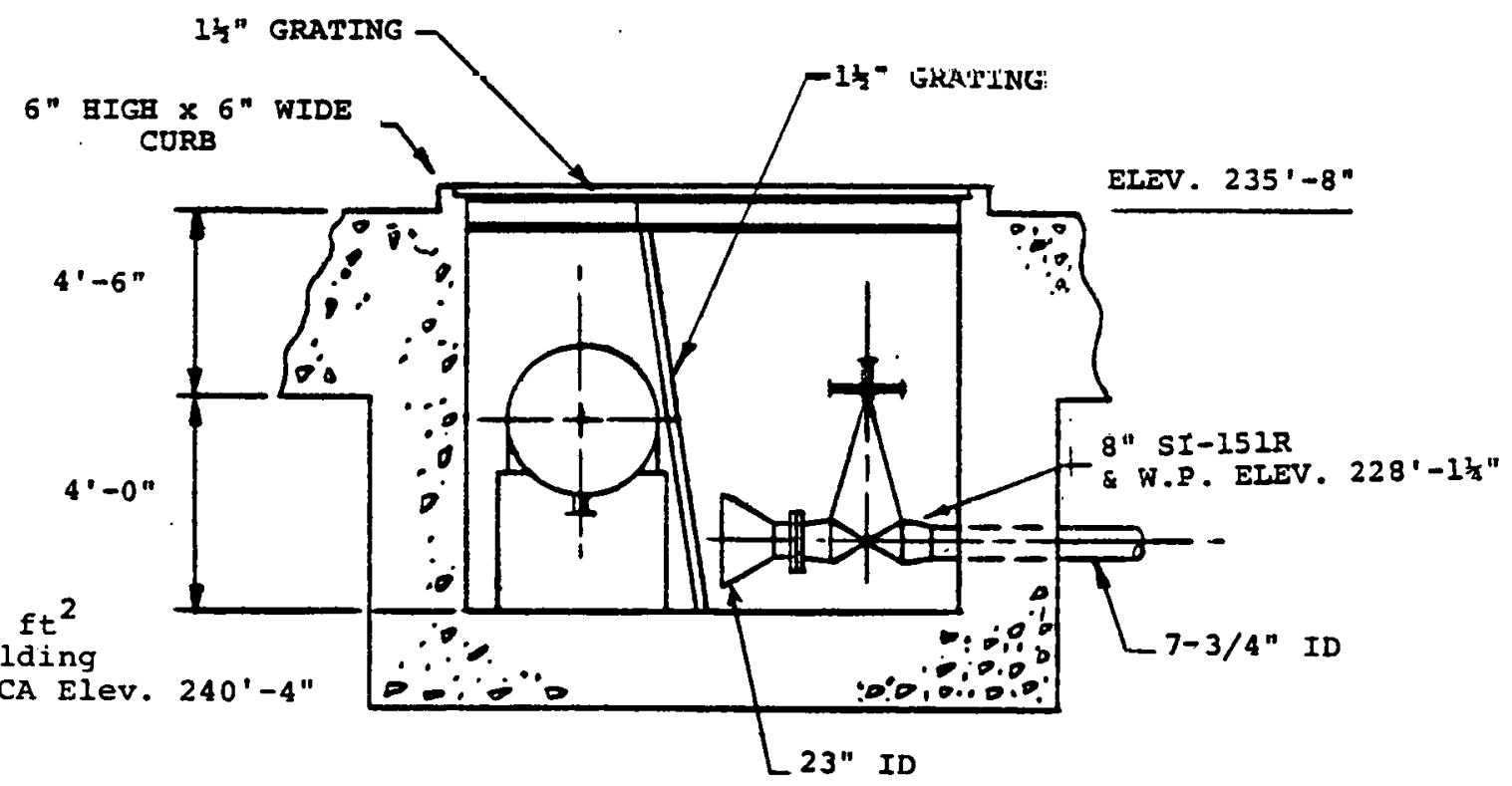

Figure E-3. Containment Sump, Robert E. Ginna 
APPENDIX $F$

PRAIRIE ISLAND UNITS $1 \& 2$

PREL IMINARY ASSESSMENT OF

INSULATION DEBRIS GENERATED DURING A

PIPE BREAK EVENT 


\section{A. INTRODUCTION}

This report documents the information gathered by Burns and Roe's survey of thermal insulation inside the primary containment of the 520 MWe, Westinghouse, PWR, Prairie Island Nuclear Station. Unit 1 started commercial operation in 1973 and Unit 2 startd commercial operation in 1974.

The information gathered depicts the following:

1. The arrangement of all piping within the primary containment including high energy fluid piping

2. The location and configuration of the emergency intake sump for emergency core cooling, and the communicating paths by which debris generated by a major pipe break could reach the emergency rcirculating sump

3. Details of the insulation that could be dislodged and become a source of debris as a result of a major break.

Reflective metallic insulation is used throughout the plant for all equipment and piping except for pipe hangers and restraints. Pipe hangers and restraints are covered with fibrous glass insulation.

\section{B. LISTING OF INPUT DRAWING AND OTHER DOCUMENTS}

This section provides a listing of drawings and documents showing details of containment and reactor building, piping, flow diagrams, emergency sump details and insulation details obtained from Northern States Power Company.

1. Documentation

a. Letter from Northern States Power Company to NRC dated January 7, 1981 on the containment sump and thermal insulation information.

2. Drawings

a. Emergency Sump Details

$$
\begin{array}{ll}
\text { NF-38407P } & \text { Reactor. Building E1. 697'-6" } \\
\text { NF-38486-3H } & \text { Concrete Sections \& Details } 1 \\
\text { Unit } 2
\end{array}
$$

b. Piping Layout Drawing

$$
\begin{array}{ll}
\text { NF-39334-1 } & \text { Residual Heat Removal Piping Unit } 1 \\
\text { NF-39334-2L } & \text { Residual Heat Removal Piping Unit } 2
\end{array}
$$




$$
\begin{aligned}
& \text { NF-39350-1F Reactor Building Composite } \\
& \text { Piping Unit } 1 \\
& \text { NF-39357-1 Floor Plan E1. 697'-6" Unit } 2 \\
& \text { NF-39350-5 Reactor Building Composite } \\
& \text { Piping Unit } 1 \\
& \text { NF-39357-5 Section A-A Unit } 2 \\
& \text { NF-39350-8D Reactor Building Composite Piping Section } \\
& \text { D-D Unit } 1 \\
& \text { NF-39357-6B Reactor Building Composite Piping Section } \\
& \text { B-B Unit } 2 \\
& \text { NF-39357-7B Reactor Building Composite Piping Section } \\
& C-C \& D-D \text { Unit } 2 \\
& \text { NF-39351-4G Reactor Building Floor Unit } 1 \\
& \text { NF-39358-4D Drain Piping E1. 697'-6" Unit } 2
\end{aligned}
$$

\section{LISTING OF PIPING INSIDE CONTAINMENT CONTAINING INSULATION}

This section provides a list of the equipment and systems inside primary containment containing insulation. The list includes the equipment, the system, nominal pipe sizes inside containment and the type of insulation used for each system.

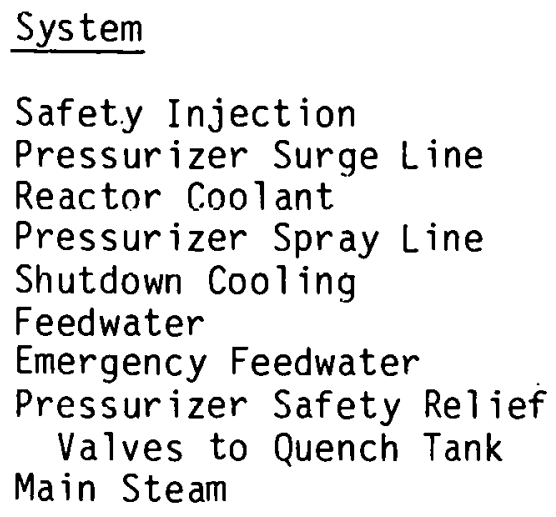

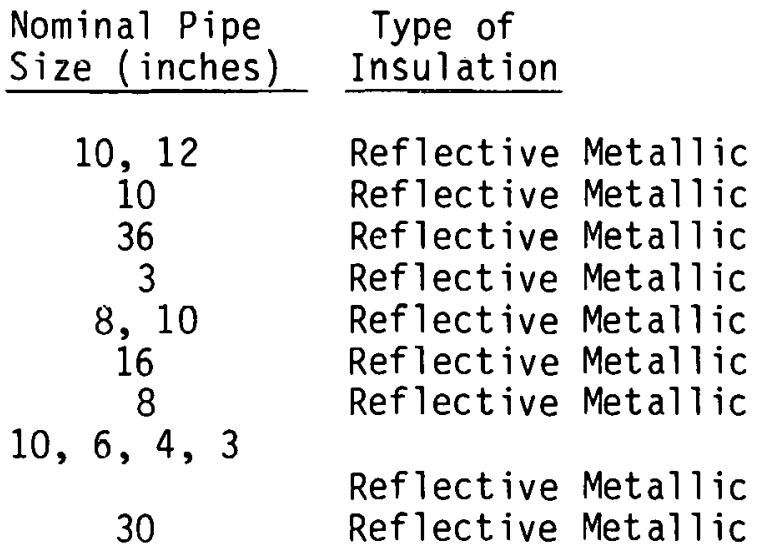


Equipment Inside

Primary Containment

Reactor Vessel

Steam Generator

Reactor Coolant Pump

Pressurizer

Main Steam \& Feedwater

Pipe Hangers \& Restraints
Reflective Metallic Reflective Metallic Reflective Metallic Reflective Metallic Fibrous Glass Blanket

\section{TYPICAL INSULATION DETAILS}

The reflective metallic insulation used for equipment and piping inside containment is described in Appendix $A$ of this report. Two insulation contractors are Mirror Insulation, a unit of Diamond Power Specialty Company and Transco, Inc., a unit of Universal Fabricated Products. The insulation material used for the reflective insulation is all stainless steel.

The fibrous glass insulation used for the main steam and feedwater pipe hanger and restraints inside containment is similar to the mineral fiber insulation described in Appendix $A$ of this report. The fibrous glass insulation consists of three one-inch thick Temp Mat manufactured by Pittsburgh Corning between two $1000^{\circ}$ glass cloth cover, CS 9383 style 1925 manufactured by Clark Schwedel Insulation. The Temp Mat has a bulk density of $11.25 \mathrm{lb} / \mathrm{ft} 3$. The three layers are held together using 18 gauge stainless steel wire threaded through the fibrous glass insulation and fastened to one inch diameter stain less steel discs which act as buttons. It is similarly held in place by 18 gauge stainless steel wire.

E. PIPE BREAK LOCATIONS

Refer to the FSAR ${ }^{1}$ for a list of the pipe break locations for high energy piping inside the primary containment.

\section{F. FSAR REFERENCES ON PERTINENT INSULATION QUESTIONS}

None were submitted by Northern States Power Company.

\section{G. PRELIMINARY INSULATION DEBRIS HAZARD ANALYSIS}

Figures $F-1$ and $F-2$ are simplified sketches of Prairie Island reactor containment. The reactor vessel, steam generators, pressurizer and associated piping are all located inside the shield wal1. The emergency sump, labeled Sump B, is located outside the shield wall on the basement floor at El. 697'-6", and the location is shown in Figure F-2. Figure F-3 and F-4 show the details of the emergency intake sump. The sump is an L shaped cavity in the floor with two pipe intakes for the emergency core cooling system. The sump is covered by a prism shaped screen constructed of $3 / 4^{\prime \prime}$ by $3-11 / 16^{\prime \prime}$ grating. The triangular ends of the screen are 2'-9" high and $2^{\prime}-11-1 / 2^{\prime \prime}$ wide and the prism length being $8^{\prime}-9-1 / 2^{\prime \prime}$. 
Insulation debris generated either inside or outside the shield wall will principly be reflective metallic with some fibrous material from the main steam and feedwater pipe hangers and restraints. Outside the shield wall, the floors should prevent insulation from reaching the sump, however, a small amount will be transported down stairwells. Inside the shield wall, platforms will catch some of the insulation, however, a large quantity can be transported to the basement floor. The reflective metallic will sink while the fibrous glass insulation will initially float and could be transported to the sump and sink.

H. REFERENCE

1. Prairie Island Units 1 and 2, Final Safety Analysis Report, Northern States Power Company, Minneapolis, MN. 


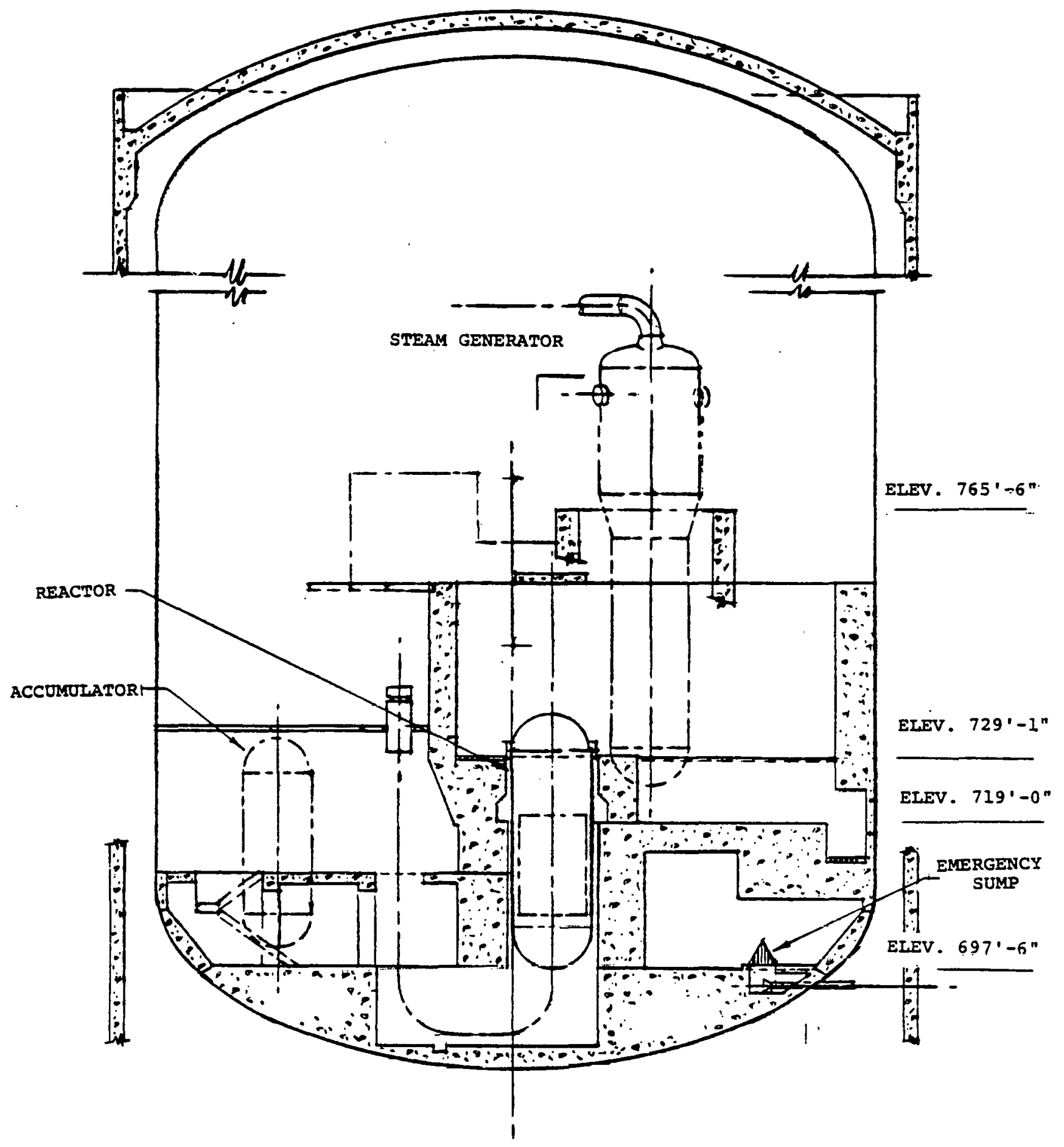

Figure F-l. Reactor Building Elevation, Prairie Island Units 1 and 2 


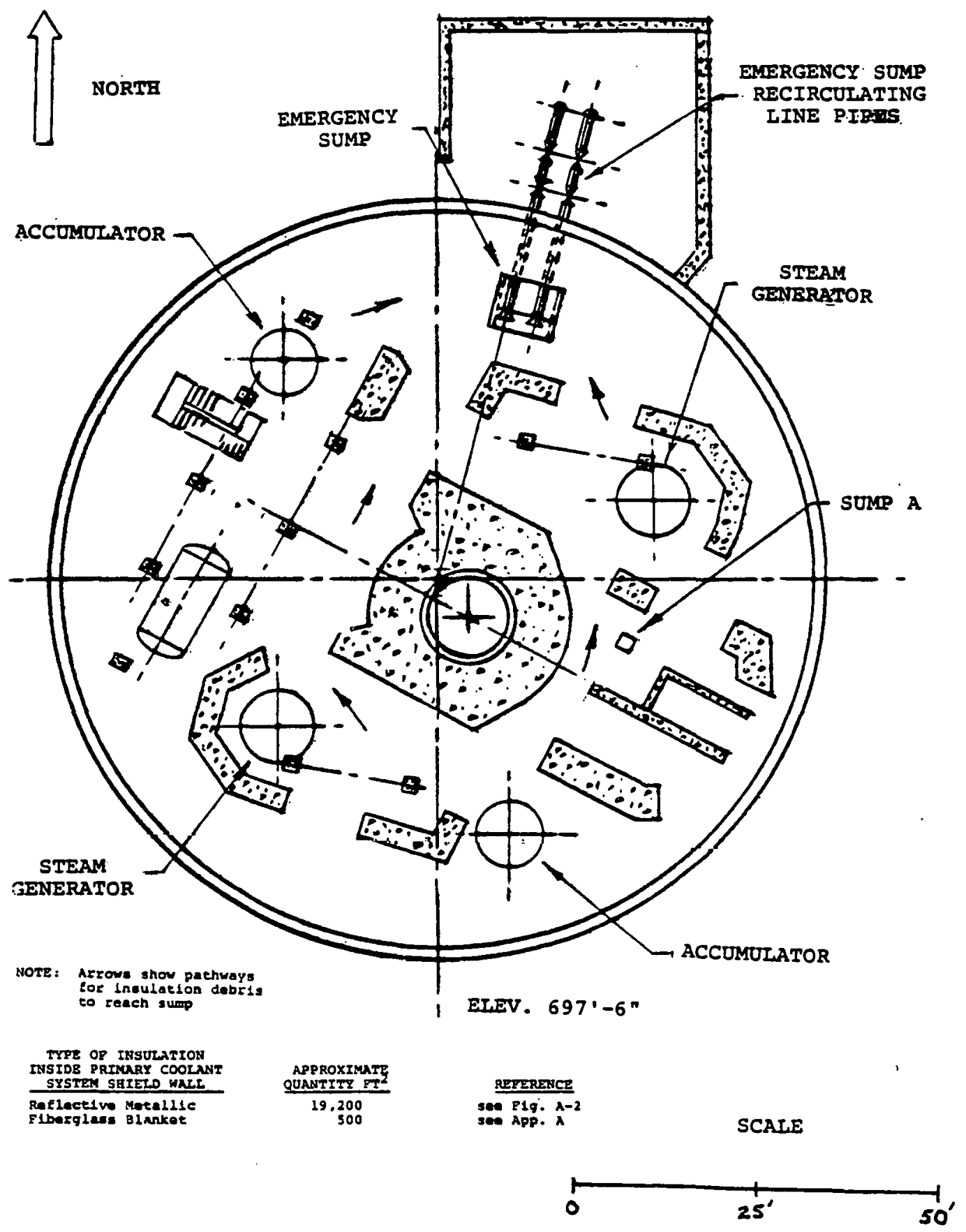

Figure F-2. Reactor Building Plan, Prairie Island Units 1 and 2 


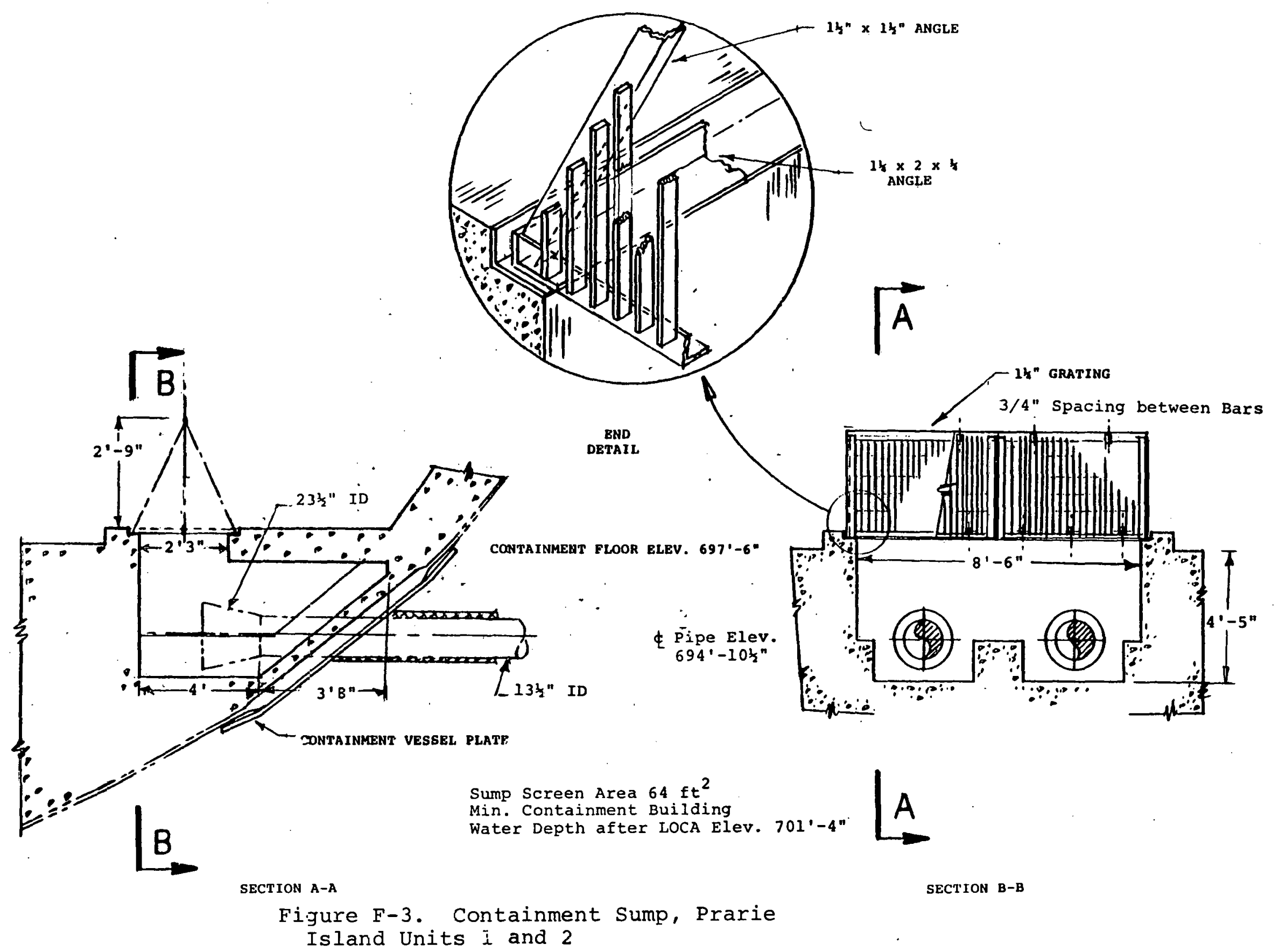




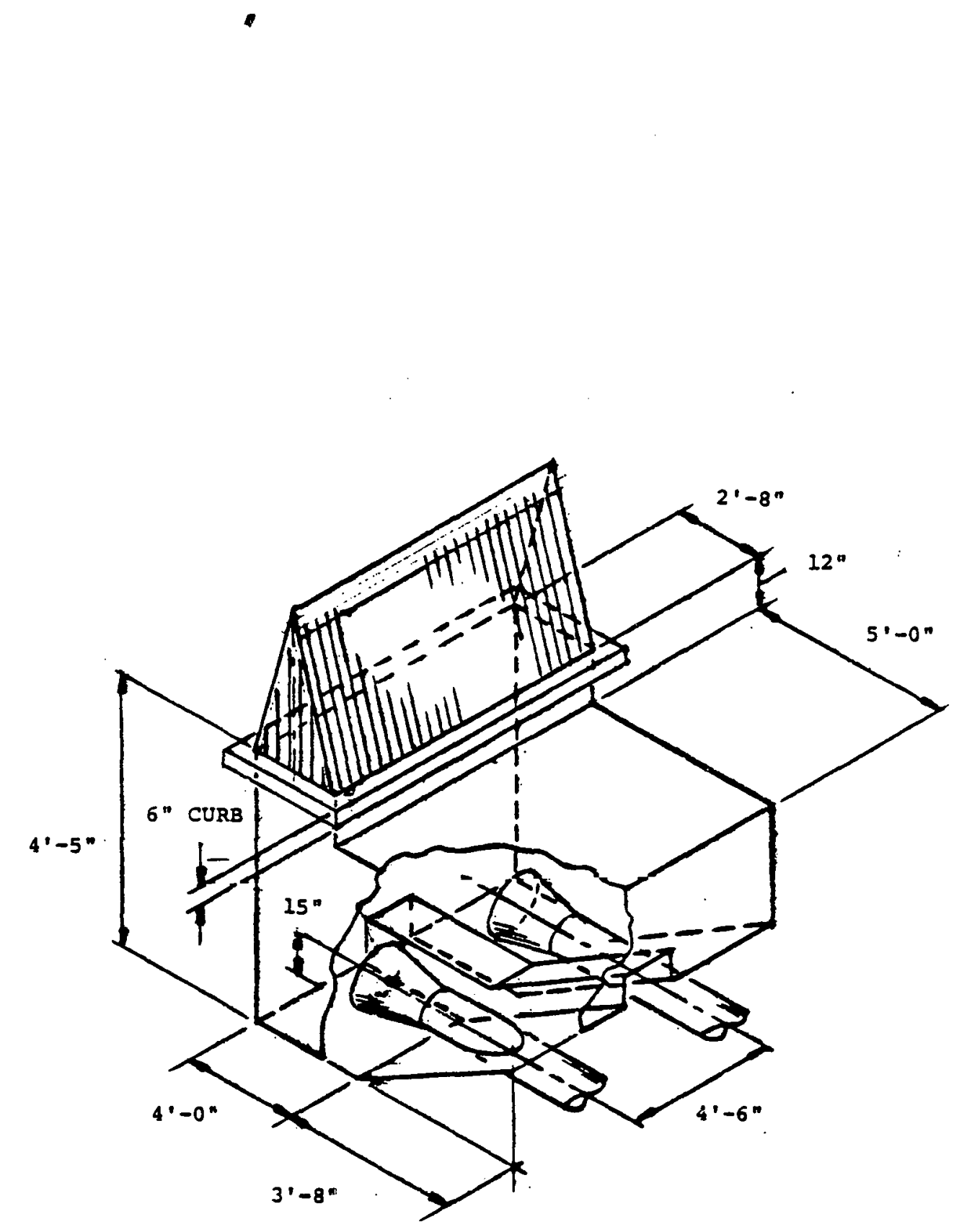

Figure F-4. Containment Sump Isometric, Prairie Island Units 1 and 2 
APPENDIX G

KEWAUNEE UNIT 1

\section{PRELIMINARY ASSESSMENT OF}

INSULATION DEBRIS GENERATED DURING A

PIPE BREAK EVENT 


\section{A. INTRODUCTION}

This report documents the information gathered by Burns and Roe's survey of the thermal insulation inside the primary containment of the 535 MWe, Westinghouse, PWR Kewaunee Unit No. 1 which began commercial operation in 1974.

The information gathered includes the following:

1. The arrangement of all piping within the primary containment including high energy fluid piping

2. The location and configuration of the sump for emergency core cooling, and the communicating paths by which debris generated by a major pipe break could reach the emergency recirculation sump

3. Details of the insulation that could be dislodged and become a source of the debris as a result of a major break.

Stainless steel reflective metallic insulation manufactured by Mirror is used for the pressurizer, reactor coolant pumps, reactor coolant piping, letdown line, safety injection piping, pressurizer surge line, residual heat removal, accumulator and a small proportion of the steam generators. Approximately 85 percent of the steam generators, main steam and feedwater piping are covered with Thermobestos block manufactured by Johns-Manville.

\section{B. LISTING OF INPUT DRAWINGS AND OTHER DOCUMENTS}

This section provides a listing of drawings and documents showing details of containment and reactor building, piping, flow diagrams, emergency sump details and insulation details obtained from Wisconsin Public Service Corporation.

\section{Documentation}

a. Letter from Wisconsin Public Service Corporation to NRC dated January 16, 1981 on insulation and the emergency sumps .

b. Letter from Wisconsin Public Service Corporation to NRC dated August 31, 1981 on the study regarding blockage of containment sumps by insulation.

2. Drawing

a. General Arrangement - Containment and Reactor Building

A204-U

Basement Floor

Sh. 2 of 11 
A210-K

Sh. 8 of 11

$S-224 F$

$S-224-1 A$

$S-225 F$

$S-253-V$

$S-254 J$

$S-254-1 G$

$S-254-3 C$

$S-254-4 A$

$S-254-5 B$
Cross Section

Elevation Steel Platforms and Ladders Inside Annulus

Miscellaneous Platforms and Details

Steel Platform Framing Plans Inside Annulus

Steel Miscellaneous Platforms

Platforms and Ladders Serving Steam Generator Manways

Miscellaneous Platforms

Miscellaneous Platforms Steam Generator Weld Inspection Platforms

Miscellaneous Platforms Serving Upper Part of Steam Pipe

Miscellaneous Platforms Serving Accumulator \& R.T.D. Valves

b. Emergency Sump Design Details

$S-237 P$

Reactor Building Concrete Sections \& Details

c. Flow Diagrams for Systems Inside Containment

$X-K 100-10-S$

$X-K 100-18-Q$

Sh. 1 of 3

$X-K 100-28 P$

$X-k 100-36-Q$

Sh. 2 of 4

M203-DD

M205-Y
Reactor, Coolant System

Auxiliary Coolant System

Safety Injection System

Chemical \& Volume Control System

Main, Auxiliary Steam Dump

Feedwater System 
d. Piping Layout Drawing for System Inside Containment

M324-AD

Sh. 1 of 2

M359-Q

Sh. 1 of 4

M360-Q

Sh. 2 of 4

M361-U

Sh. 3 of 4

M362-S

Sh. 4 of 4

M363-Y

Sh. 1 of 5

M364-Y1

Sh. 2 of 5

M365-Y

Sh. 3 of 5
Residual Heat Removal

Chem: \& Vol. Control, Auxiliary Coolant \& Safety Injection

Chem. \& Vol. Control, Auxiliary Coolant \& Safety Injection

Chem. \& Vol. Control, Auxiliary Coolant \& Safety Injection

Chem. \& Vol. Control, Auxiliary Coolant \& Safety Injection

Chem. \& Vol. Control, Sample, Reactor Coolant, Waste Disposal

Chem. \& Vol. Control, Sample, Reactor Coolant, Waste. Disposal

Chem. \& Vol. Control, Sample, Reactor Coolant, Waste Disposal

e. Reactor Building Equipment and Equipment Insulation Drawings

$X-K 310-2$

$\mathrm{X}-\mathrm{K} 310-7$

$x-310-8$

$\mathrm{X}-\mathrm{K} 310-11$

$x-K 310-13$

$\mathrm{X}-\mathrm{K} 310-19$

$\mathrm{X}-\mathrm{K} 310-23$

$X-K 310-27$

$\mathrm{X}-\mathrm{K} 310-30$

$\mathrm{X}-\mathrm{K} 310-32$

$x-k 310-34$
Mirror Insulation Arrangement for $1000 \mathrm{Cu}$. Ft. Pressurizer

Low Head Safety Injection a

E1. 517'-10-3/4"

Coolant Piping Insulation

Intermediate Coolant Leg Loup B

Steam Generator 1-A Bottom Head

Shell Insulation

Coolant Pump Insulation Arrangement

Insulation Support Frame Details

Accumulator Injection Loop A \& Loop B

8" Residual Heat Removal Act

Surge Line Insulation

Encapsulation - Main Steam Piping 


$$
\begin{array}{ll}
\mathrm{X}-\mathrm{K} 310-36 & \text { Encapsulation - Feedwater Piping } \\
\mathrm{X}-\mathrm{K} 310-45 & \text { 2" Auxiliary Spray Line From 3" } \\
& \text { Pressurizer Spray Line } \\
\mathrm{X}-\mathrm{K} 310-48 & \text { Safety Injection Loops A \& B } \\
\mathrm{X}-\mathrm{K} 310-49 & \begin{array}{l}
\text { 2 Charging Line to Regenerative } \\
\text { Heat Exchanger }
\end{array}
\end{array}
$$

\section{LISTING OF PIPING INSIDE CONTAINMENT CONTAINING INSULATION}

This section provides a list of the systems inside the reactor containment containing insulation. The list includes the system, nominal pipe sizes inside containment, and the type of insulation used for each system.

System

Safety Injection

Reactor Coolant System

Pressurizer Surge Line

Pressurizer Spray Line

Reactor Drain Line

Shutdown Cooling System

Feedwater

[meryency Feedwater

Pressurizer Safety

Rel ief Valve Lines

Main Steam

Equipment Inside

Primary Containment

Steam Generator

Reactor Coolant. Pumps

Reactor Vessel

Pressurizer

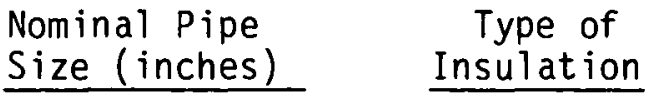

$2,3,6$
$27-1 / 2,29,31$
10
3
1,2
$6,8,10$
16
4
$6,6,10$

30
Reflective Metallic Reflective Metallic Reflective Metallic Reflective Metallic Reflective Metallic Reflective Metallic Thermobesto3 Thermobestos

Reflective Metallic Thermobestos

D. TYPICAL INSULATION DETAILS

The reflective metallic insulation used for equipment and piping inside containment is manufactured by Mirror Insulation, a unit of. Diamond Power Specialty Company. The insulating material used for the reflective insulation is all-metal AISI type 304 stainless steel. The reflective metallic is fastened by one of the following methods: buckles and screws, pop rivets, buckles and keeper, stainless steel band and buckles, stainless steel bands or buckles. 
Thermobestos is manufactured by Johns-Manville. The Thermobestos is asbestos fibers mixed with an inorganic hydrous calcium silicate binder encapsulated using AISI type 304 stainless steel. It is fastened by stainless steel bands.

\section{E. PIPE BREAK LOCATIONS}

Refer to the FSAR ${ }^{1}$ for a list of the pipe break locations for high energy piping inside the primary containment.

\section{F. FSAR REFERENCES ON PERTINENT INSULATION QUESTION}

None were submitted.

\section{G. PRELIMINARY INSULATION DEBRIS HAZARDS ANALYSIS}

Figures G-1 and G-2 are simplified sketches of the Kewaunee Unit No. 1 reactor containment building. The reactor vessel, steam generators, reactor coolant pumps, pressurizer and associated piping are located inside the shield wall. The location of the emergency sump on the basement floor at El. 592'-0" is shown in Figure G-2 and is outside the shield wall. Figures G-3 and G-4 show the details of the emergency intake sump. The sump is an $L$ shaped cavity in the floor with two pipes intakes for the emergency core cooling system. Covering the sump is a flat rectangular checker plate with two cone shaped screens over each intake pipe. The conical shaped screens are basket stainless steel type 304 water strainer catalog Johnson Screens by U.O.P. Saint Paul, Minnesota. Opening slots within the screen are $1 / 8$ " wide with $60 \%$ open area.

Outside the shield wall, the potential for large amounts of the insulation debris reaching the sump is sinall. A floor at El. 606 '-0" will capture most of the insulation before it reaches the basement floor. However, a small amount of insulation will migrate to the basement floor through stairwells and other openings in the floor. The potential for large amounts of insulation debris reaching the sump from inside the shield wall exists. Two partial floors exist within the shield wall at El. 605'-4" and El. 609'-1". Although these floors will capture much of the insulation, some could pass through the gap between the two floors to reach the sump. Any insulation below the floor at El. 606'-0" and El. 605'-4" will reach the basement floor. In the region surrounding the sump, there exists several pipes above the sump. The largest of these pipes is a 10 inch residual heat removal pipe. A pipe break could dislodge the insulation from these pipes and the insulation could land on the sump.

The insulation debris generated from a pipe break will be a mixture of reflective metallic and the Thermobestos. The reflective metallic will sink and the Thermobestos, because of its density (11 lb/ft 3 ), will float and then sink as it absorbs water.

\section{H. REFERENCE}

1. Kewaunee, Final Safety Analys is Report, Wiscons in Public Service Corporation, Green Bay, WI. 


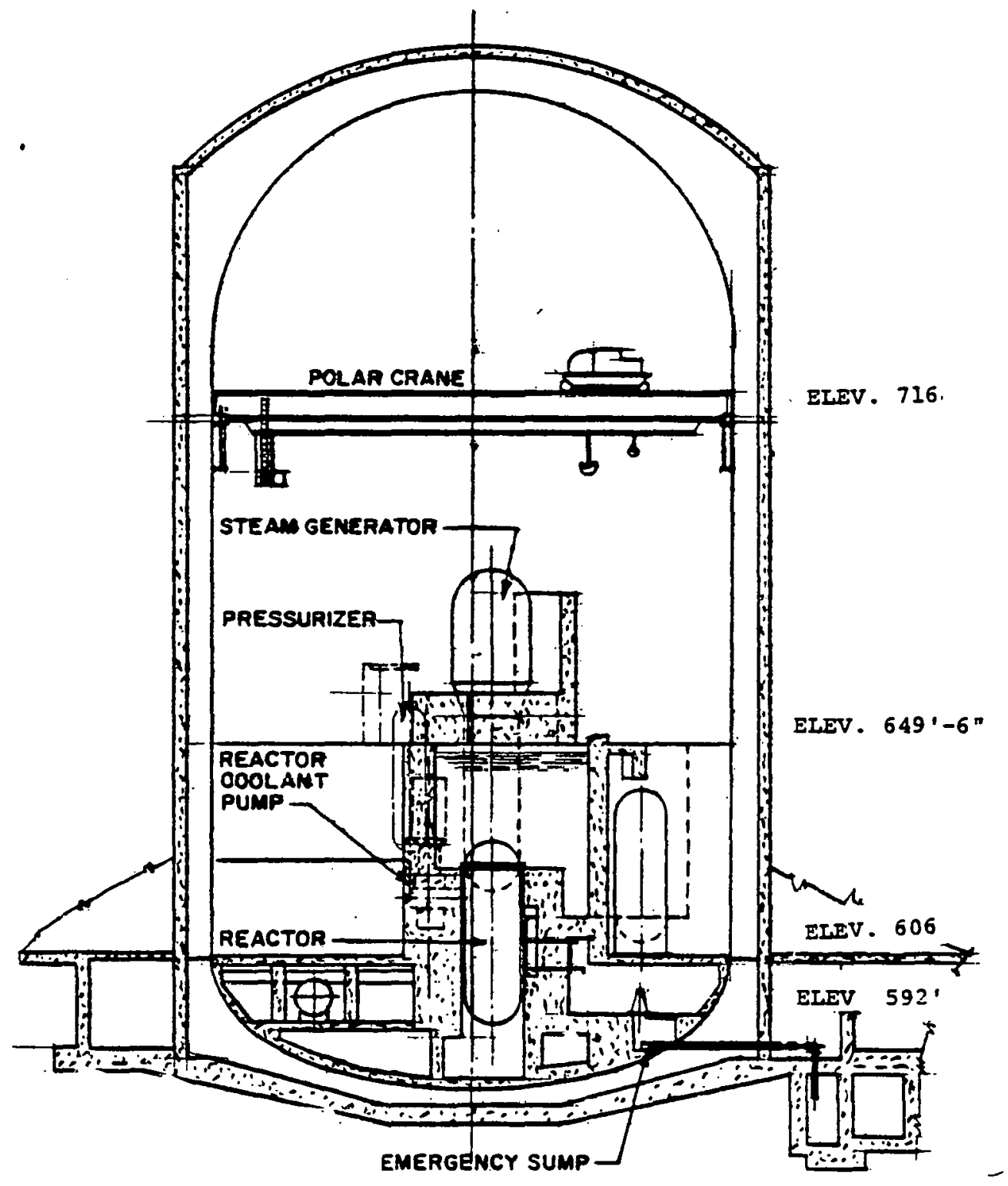

Figure G-1. Reactor Building

Elevation, Kewaunee 


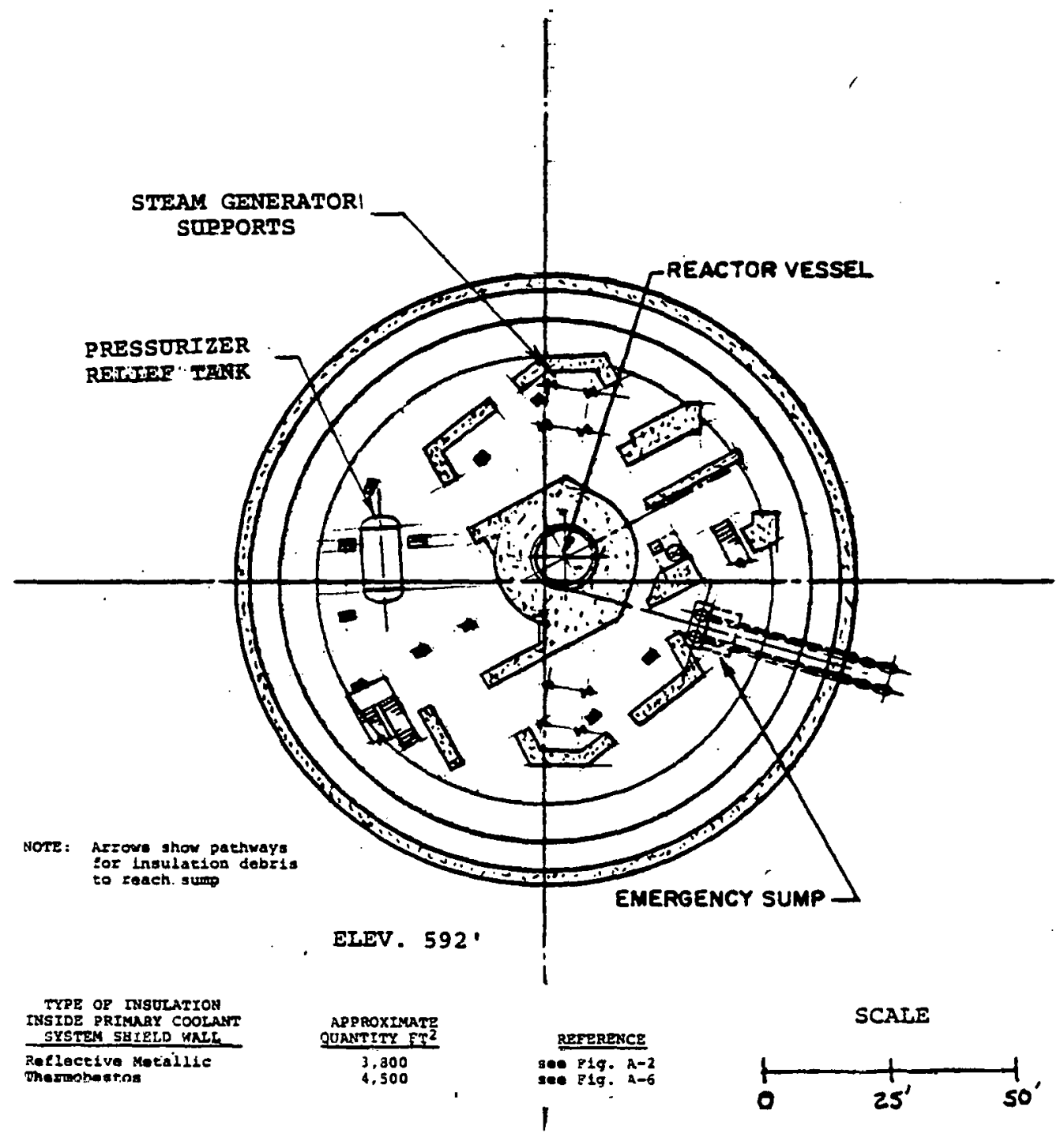

Figure G-2. Reactor. Building

Plan, Kewaunee 


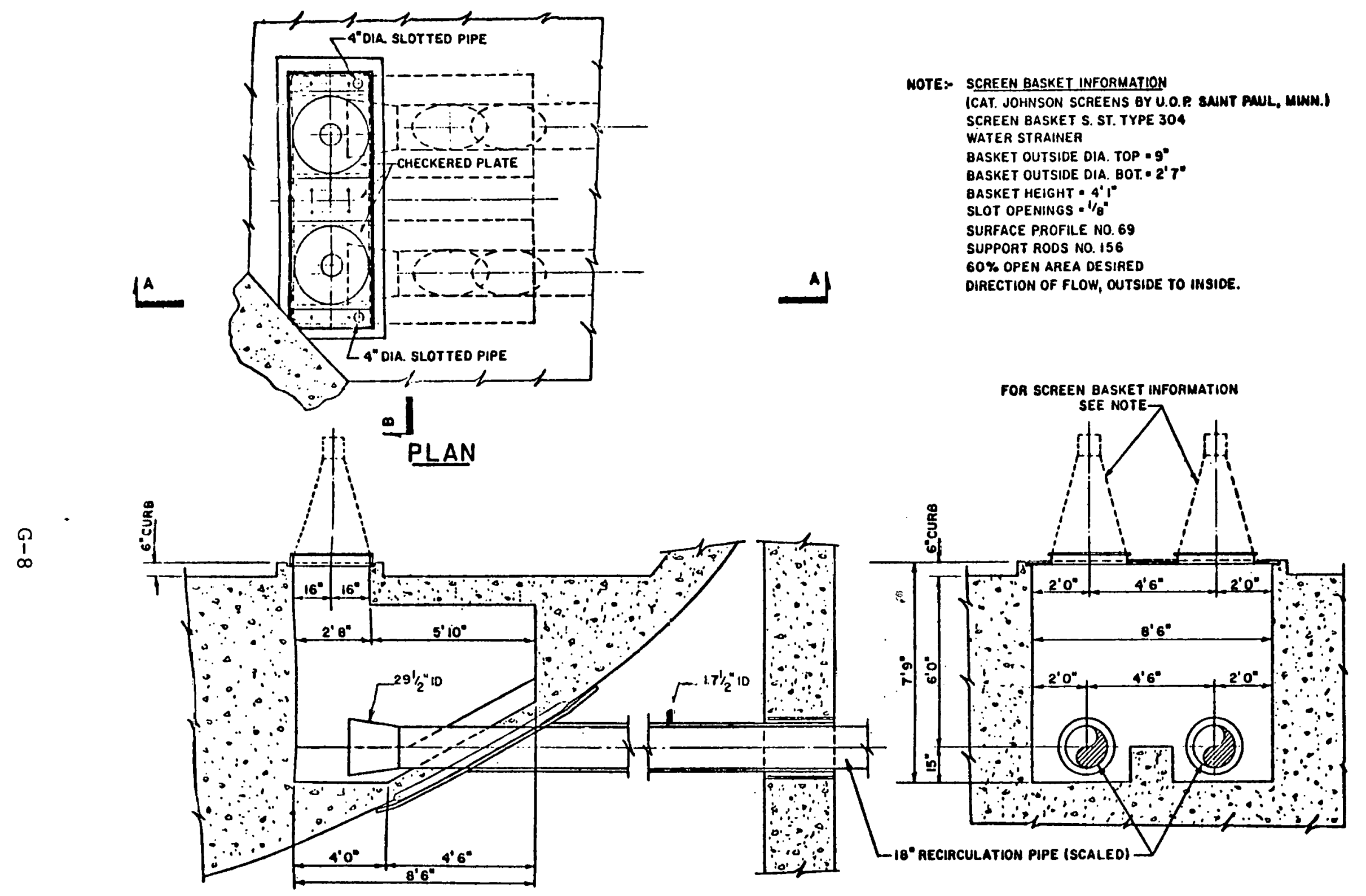

Sump Screen Area $94 \mathrm{ft}^{2}$

SECTION A-A

SECTION B-B

Min. Containment Building

Water Depth after LOCA Elev. 595'-9"

Figure G-3. Containment Sump, Kewaunee 


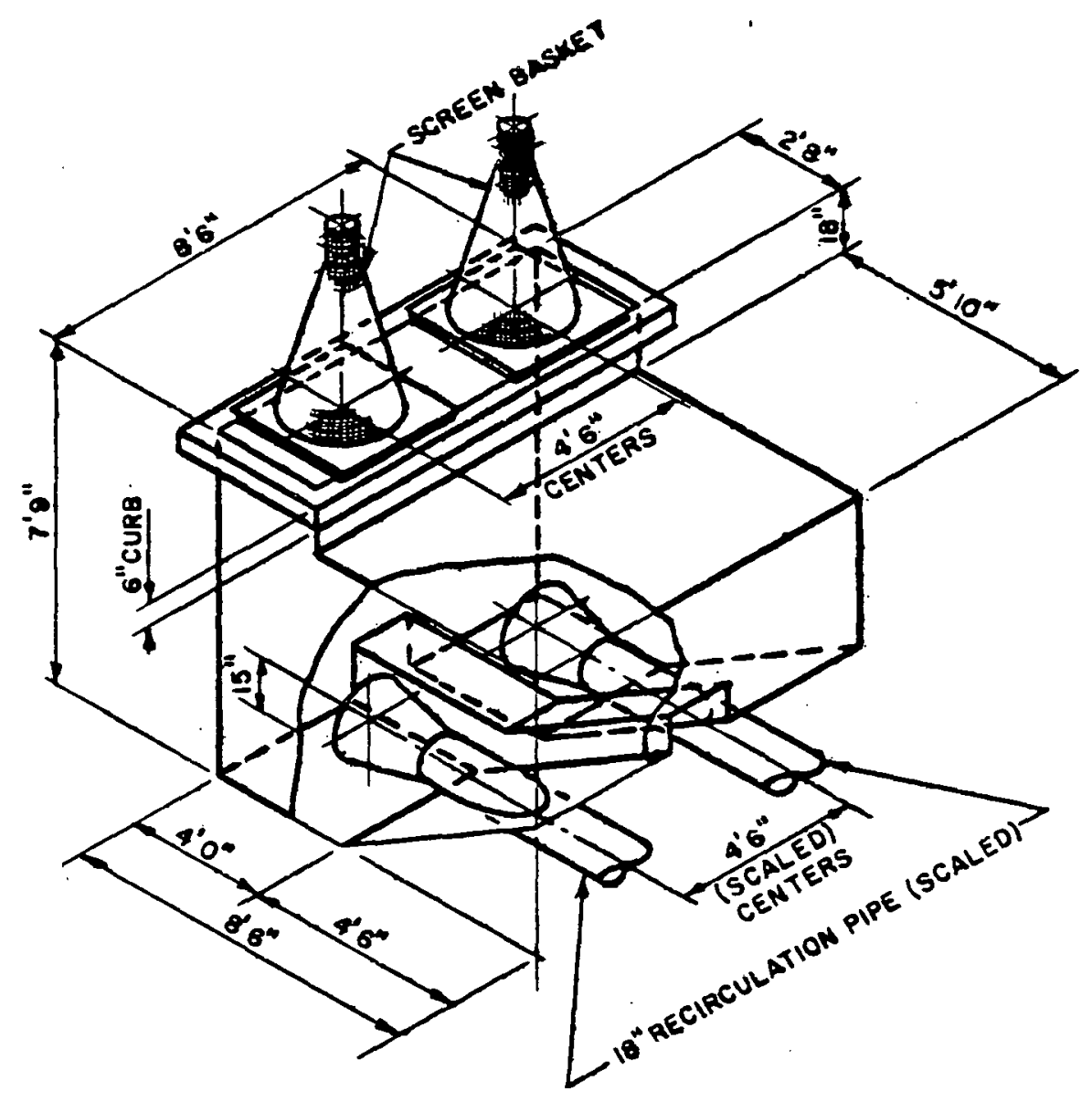

Figure G-4. Containment Sump Isometric, Kewaunee 
APPENDIX H

HADDAM NECK UNIT 1

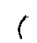

PREL IMINARY ASSESSMENT OF

INSULATION DEBRIS GENERATED DURING A

PIPE BREAK EVENT 


\section{A. INTRODUCTION}

This report documents the information gathered by Burns and Roe's survey of thermal insulation inside the primary containment of the 575 MWe Westinghouse, PWR, Haddam Neck Station which started commercial operation in 1968.

The information gathered depicts the following:

1. The arrangement of all piping within the primary containment including high energy fluid piping

2. The location and configuration of the sump for emergency core cooling, and the communicating paths by which debris generated by a major pipe break could reach the emergency recirculating sump

3. Details of the insulation that could be dislodged and become a source of debris as the result of a major break.

Thermobestos insulation is used for the reactor pressure vessel and hot pipes. Fiberglass insulation is used at valves and welds for the removable sections. Foam insulation is used for the cold water pipes.

\section{B. LISTING OF INPUT DRAWINGS AND OTHER DOCUMENTS}

This section provides a listing of drawings and documents showing details of containment and reactor building, piping, flow diagrams, emergency sump details and insulation details obtained from Connecticut Yankee Atomic Power Company and Northeast Utilities.

1. Documentation

a. Letter from Connecticut Yankee Atomic Power Company to Nuclear Regulatory Commission dated February 27, 1981 on the insulation within the plant.

2. Drawings

a. General Arrangement - Containment and Reactor Building

$10899-F M-2 A$

$10899-F M-2 B$

$10899-F M-2 C$

$10899-F M-2 D$

$10899-F M-2 E$

$10899-F M-2 F$
Containment EL $1^{\prime} 6^{\prime \prime}$ and $\mathrm{EL}(-) 16^{\prime} 0^{\prime \prime}$

Containment EL $16^{\prime} 0^{\prime \prime}$

Containment EL $22^{\prime} 0^{\prime \prime}$

Containment EL $48^{\prime} 6^{\prime \prime}$

Containment Sections $A A$ and $B B$

Containment Sections CC and DD

b. Emergency Sump Design Details taken from General

Arrangement Drawing 
c. Flow Diagrams for Systems Inside Containment

\author{
$10899-F M-12 A$ \\ $540 \mathrm{~F} 415$ \\ $540 F 416$ \\ $540 \mathrm{~F} 420$ \\ 10899-RM-6A
}

16103-26013

Sht. 2

10899-RM-7A

10899-RM-39A
Misc. Lines

Reactor Coolant System

Auxiliary Coolant System

Safety Injection System

Condensate Feedwater and Heater

Drain Lines

Condensate Feedwater and

Drain Lines

Circ. and Service Water Lines

Operating Valve Numbers Main, Aux. St., Extraction St. and Air Removal Lines

d. Piping Layout Drawings for Systems Inside Containment

$$
\begin{aligned}
& 10899-F P-3 C \\
& 10899-F P-3 D \\
& 10899-F P-3 E \\
& 10899-F P-3 F \\
& 10899-F P-3 G \\
& 10899-F P-3 H \\
& 10899-F P-3 J \\
& 10899-F P-3 K \\
& 10899-F P-3 L \\
& 10899-F P-3 M \\
& 10899-F P-3 N \\
& 10899-F P-3 Q \\
& 10899-F P-3 R \\
& 10899-F P-3 S \\
& 10899-F P-3 T \\
& 10899-F P-3 W
\end{aligned}
$$

e. Reactor Building Equipment and Equipment Insulation Drawing None were provided

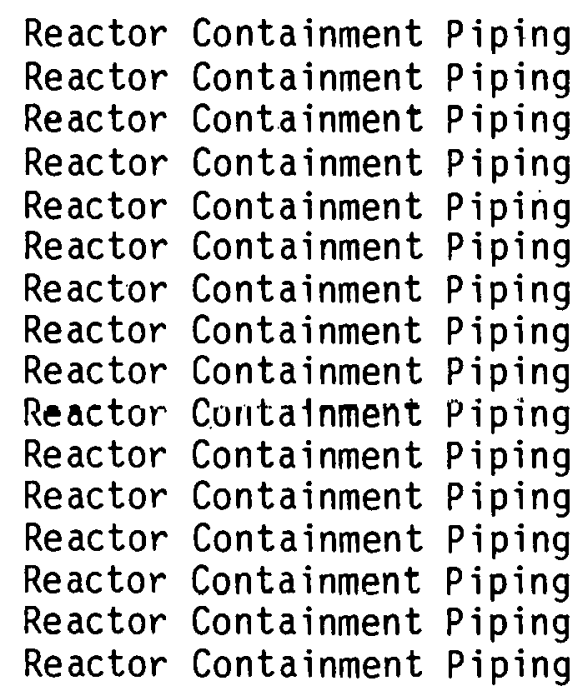

e. Reactor Building Equipment and Equipment Insulation Drawing

\section{LISTING OF PIPING SYSTEMS INSIDE. CONTAINMENT CONTAINING INSULATION}

This section provides a list of the equipment and systems inside primary containment containing insulation. The list includes the equipment, the system, nominal pipe sizes inside containment and the type of insulation used for each system. 
System

Safety Injection

Pressurizer Surge Line

Reactor Coolant System

Reactor Drain Lines

Shutdown Cooling

Feedwater

Emergency Feedwater

Ma in Steam

Service Water

Charging Line

Pressurizer Reflief Line

Equipment Inside Primary Containment

Reactor Vessel

Reactor Coolant Pump

Pressurizer

Steam Generator

Containment Wall \begin{tabular}{ll} 
Nominal Pipe & Type of \\
Sizes (inches) & Insulation \\
\hline
\end{tabular}

6,8
10
$27-1 / 2,29$
$1,1-1 / 2,2$
4,8
12
6
24
$1,2,3,6$
10
3,10

Thermobestos

Thermobestos

Thermobestos

Thermobestos

Thermobestos

Thermobestos

Thermobestos

Thermobestos

Foam Insulation

Calcium Silicate

Calcium Silicate

All valves, welds, etc., requiring removable insulation are covered with fiberglass.

\section{TYPICAL INSULATION DETAILS}

The Thermobestos, manufactured by Johns-Manville, is asbestos fiber mixed with an inorganic hydrous calcium silicate binder. It is fastened with stainless steel wire and either asbestos cement and aluminumin impregnated asbestos cloth or asbestos paper and aluminum impregnated asbestos cloth. The fiberglass, manufactured by $\mathrm{Clarmont}$, is wired in place with stainless steel wire and enclosed in aluminized glassback cloth. The foam insulation is Acrotube, molded from plastic manufactured by Julurs-Manville. It is hold in place with Jnhns-Manville 57 Adhesive and tape. The polyurethane is also manufactured by Johns-Manville. It is held in place with adhesive and covered with aluminum impregnated asbestos cloth. The reflective metallic is manufactured by Transco and is held in place with stainless steel banding. The calcium silicate manufactured by Johns-Manville is Thermal 12. The blocks are retained by 10 gauge aluminum jacket and banded in place.

E. PIPE BREAK LOCATIONS

Design Basis Accident pipe breaks are defined as:

1. Steam line rupture at the Steam Generator outlet nozzle

2. Loss-of-coolant accident - double-ended guillotine break in the cold leg at the reactor coolant pump discharge. 


\section{F. FSAR REFERENCES ON PERTINENT INSULATION QUESTIONS}

None weré submitted by Connecticut Yankee Atomic Power Company.

\section{G. PRELIMINARY INSULATION DEBRIS HAZARD ANALYSIS}

Figures $\mathrm{H}-1$ and $\mathrm{H}-2$ are simplified sketches of the Haddam Neck reactor containment building. The reactor vessel, steam generators, reactor coolant pumps, pressurizer, and associated piping are located inside the shield wall. Figure $\mathrm{H}-2$ shows the location of the emergency sump on the floor of the containment building at an elevation of $1^{\prime}-6^{\prime \prime}$. Figure $\mathrm{H}-3$ shows the details of the emergency sump. The sump is a part of the reactor building sump and has a screen and weir partitioning it from the remainder of the normal sump. Drainage trenches around the outside of the reactor vessel containment wall and around the outside of the shield wall drain into the normal sump and thereby connect to the emergency sump. The drainage trenches are shown in Figure $\mathrm{H}-2$ and are covered by grating. The sump is located adjoining the inside of the shield wall and adjoining a wall which shields the sump from reactor coolant loop number 1 . The sump is also shielded from reactor coolant loop number 4 by the fuel transfer canal. A floor is located over the sump at $22^{\prime} 0^{\prime \prime}$.

For a pipe break inside the shield wall, the possibility exists for a large amount of insulation to migrate towards the sump and sink. Since most of the insulation will initially float, it could be transported toward the sump once recirculation has begun. For a pipe break outside the shield wall, the potential for a large amount of insulation to migrate towards the sump is very small. A concrete and grate floor exist at El. 22' and would catch most of the insulation. However, a small amount of, insulation could migrate down the stairwells and other openings. For a pipe break below the floor at 22', the insulation could migrate to the sump through any hole in the shield wall. 


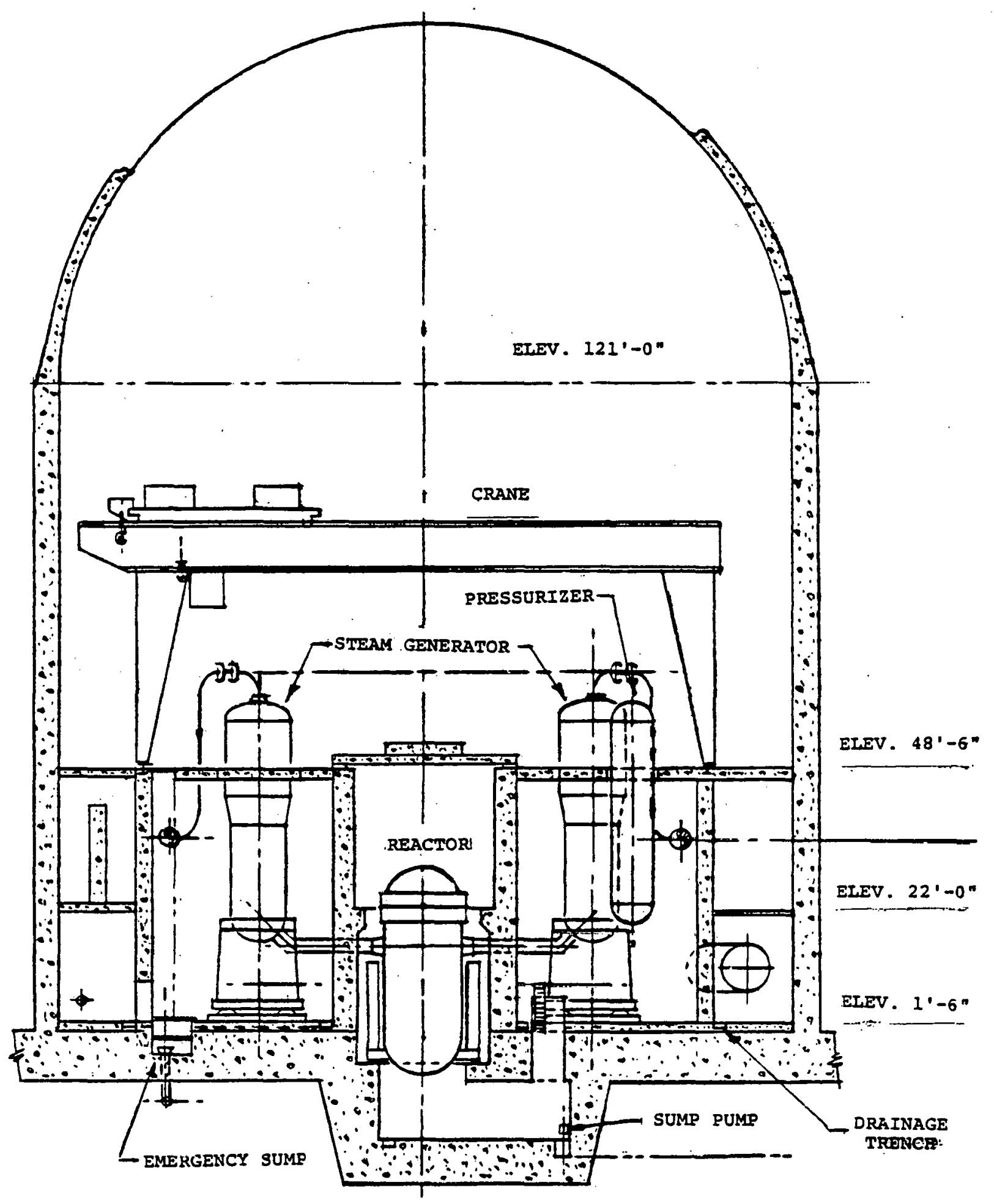

Figure $H-1$ Reactor Building Elevation, Haddam Neck 


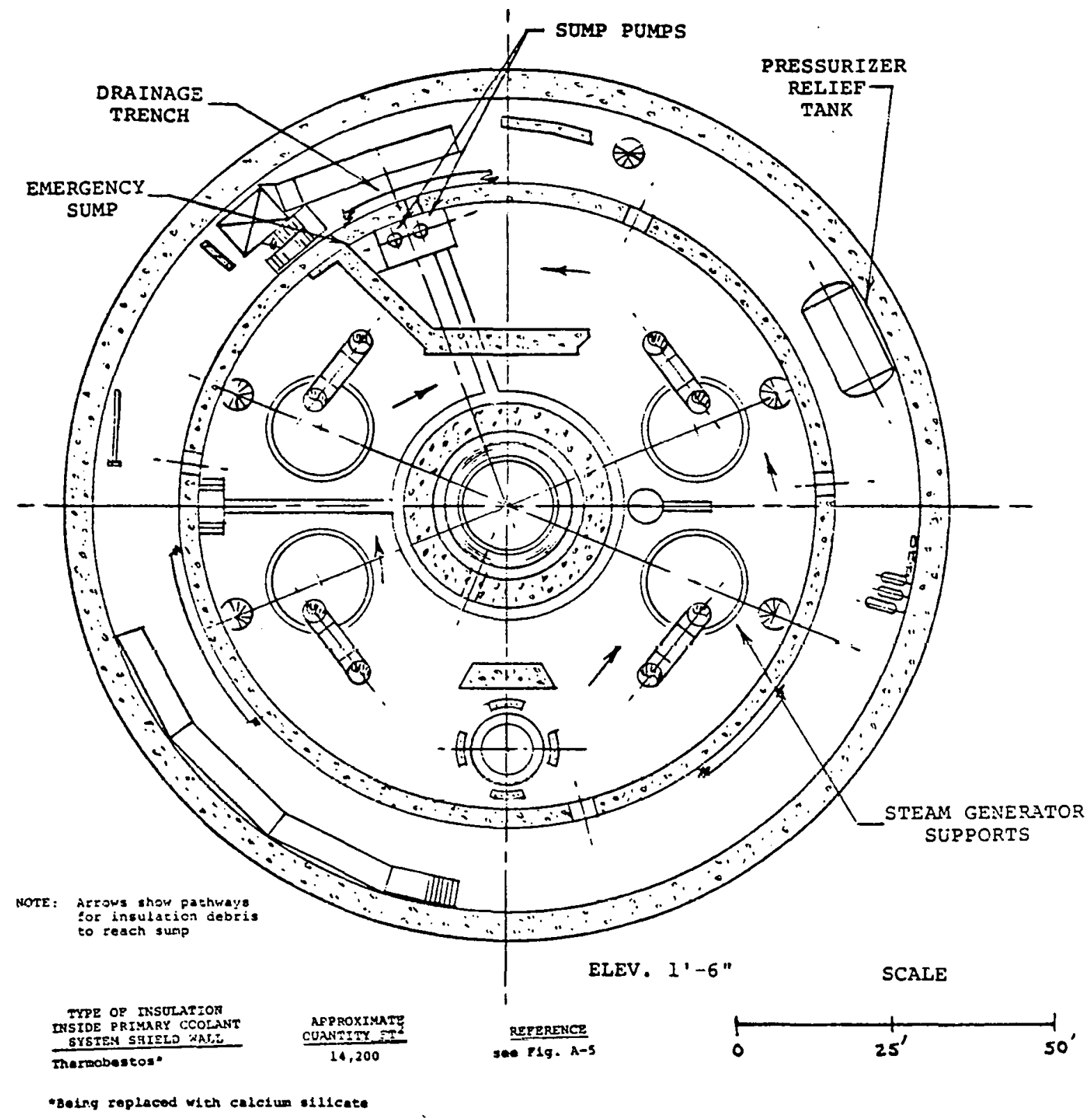

Figure H-2. Reactor Building Plan, Haddam Neck 

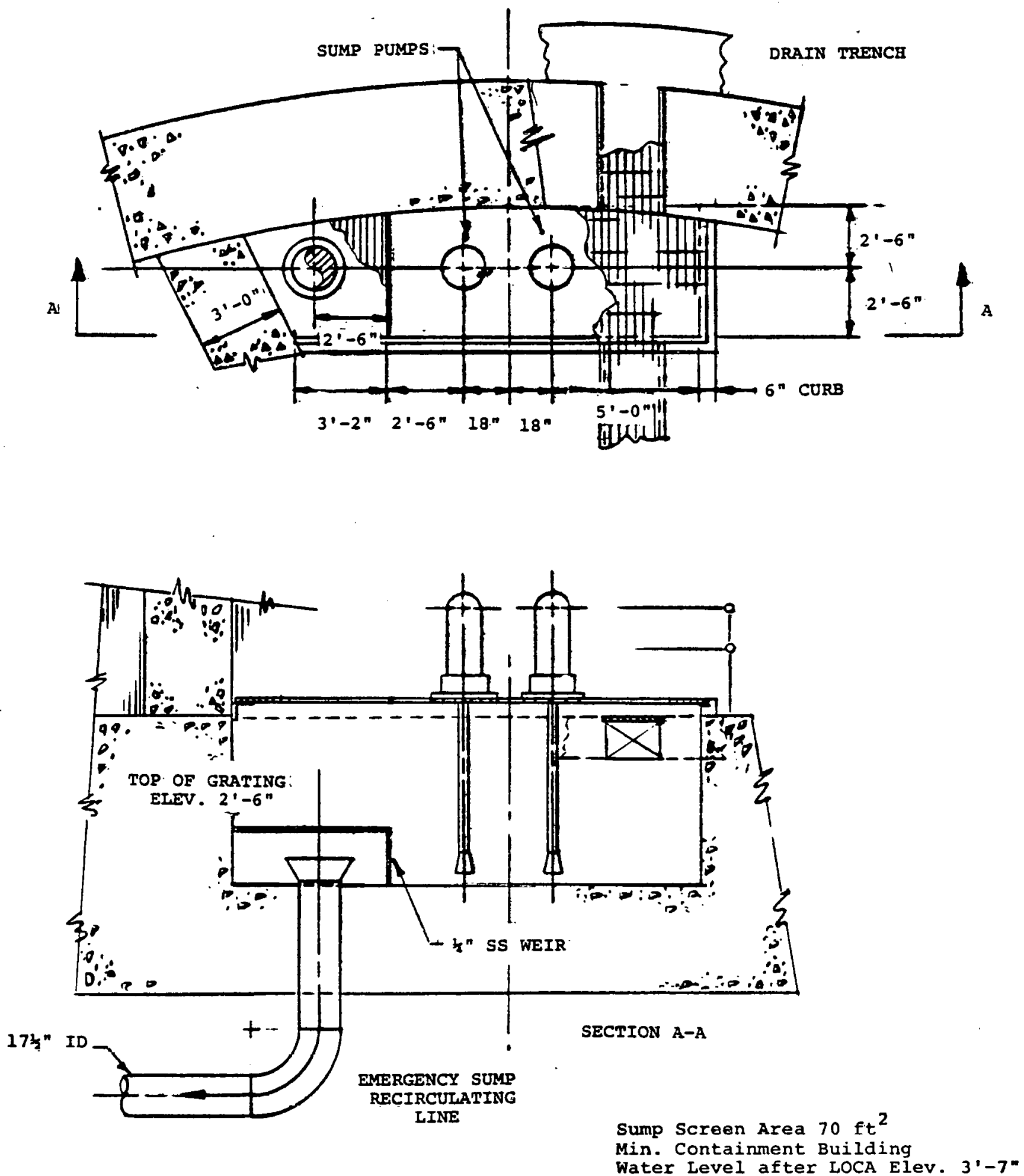

Figure H-3. Containment sump, Haddam Neck 
APPENDIX I

H. B. ROBINSON

PREL IMINARY ASSESSMENT OF

INSULATION DEBRIS GENERATED DURING A

PIPE BREAK EVENT 


\section{A. INTRODUCTION}

This report documents the information gathered by Burns and Roe's survey of thermal insulation inside the primary containment of the 665 MWe Westinghouse, PWR, H.B. Robinson Nuclear Station which started operation in 1971.

The information gathered depicts the following:

1. The arrangement of all piping within the primary containment including high energy fluid piping

2. The location and configuration of the emergency intake sump for emergency core cooling, the communicating paths by which debris generated by a major pipe break could reach the emergency recirculation sump

3. Details of the insulation that could be dislodged and become a source of debris as a result of a major break.

Unibestos block and pipe covering was initially used throughout the plant for all equipment and systems. Presently, new or replacement insulation is Thermon-12 manufactured by Johns-Manville Company. Approximately 15 percent of the originally installed insulation has been replaced by Thermon-12.

\section{B. LISTING OF INPUT DRAWINGS AND OTHER DOCUMENTS}

This section provides a listing of drawings and documents showing details of containment and reactor building, piping, flow diagrams, emergency sump details and insulation details obtained from Carolina Power \& Light Company or the NRC.

1. Documentation

a. Letter from Carolina Power \& Light Company to NRC dated February 24, 1981 on the containment sumps and insulation.

2. Drawings

List of Safety Analys is Report Figures provided by NRC

Figure 1.2-2

Figure 1.2-3

Figure 1.2-4
General Arrangement Reactor Building Plans Sheet 1

General Arrangement Reactor Building Plans Sheet 2

General Arrangement Reactor Building Sections 
Figure 5.1.2-37

Figure $6.2-2$

Figure 6.2-3

Figure $6.2-4$

Figure 6.2-5
Reactor Building Base Slab Sections Mas.

Safety Injection System - Plan Sheet 1

Safety Injection System - Plan Sheet 2

Safety Injection Systems Sections

Residual Heat Removal Piping

\section{LISTING OF PIPING INSIDE CONTAINMENT CONTAINING INSULATION}

This section provides a list of the equipment and systems inside primary containment containing insulation. This list includes the equipment, the system, nominal pipe sizes inside containment and the type of insulation used for each system.

System

Chemical and Valve Control

Reactor Coolant

Safety Injection

Component Cooling Water

Service Water

Steam Generator Blowdown

Ma in Steam

Residual Heat Removal

Sampling System

Equipment Inside

Primary Containment

Steam Generator

Pressurizer

Regenerative Heat

Exchanger

Reactor Coolant Pump

Excess Letdown Heat

Exchanger
Nominal Pipe

Size (inches)

Not Provided

Not Provided

10

Not Provided

Not Provided

Not Provided

Not Provided

Not Provided

Not Provided
Type of

Insulation

Un ibes tos*

Un ibestos*

Un ibestos*

In ihestons*

Unibestos*

Unibestos*

Unibestos*

Unibestos*

Unibestos*

* 15 percent of the Unibestos insulation has been replaced with Thermon-12, a molded hydrous calium silicate. 


\section{TYPICAL INSULATION DETAILS}

The Unibestos insulation used inside containment is of molded construction. For all piping 12 inch nominal diameter and smaller, 36 inch sections having not more than two longitudinal joints were used. For all piping over 12 inch nominal diameter and all bends 2 piece block molded to fit the circumference of the pipe were used. All segmental blocks were butted together and wired in place with No. 16 gage annealed iron wire. The ends of all wire loops were firmly twisted together with pliers, bent over and carefully pressed into the surface of the insulation. All irregularities in the insulation were smoothed out with an application of hard finish cement, composed on the same material as the molded insulation blocks, sufficient only to provide a uniform, even surface but not intended as a hard cement finish coat. Finally, a layer of white duck was applied to the insulation.

\section{E. PIPE BREAK LOCATIONS}

None were provided.

\section{F. FSAR REFERENCES ON PERTINENT INSULATION QUESTIONS}

None were referenced.

\section{G. PRELIMINARY INSULATION DEBRIS HAZARD ANALYSIS}

Figures I-1 and I-2 are simplified sketches of the H. B. Robinson Unit 2 reactor containment. The reactor vessel, steam generators, pressurizer and associated piping are located inside the shield wall. The accumulator and its associated piping are located outside the shield wall. The emergency sump is located outside the shield wall on the basement floor at El. 228'-0". Figure I-2 shows the sump location and screens on the outside of the shield wall. The details of the emergency intake sump are shown in Figure I-3. The sump, a pit in the floor $1 \mathrm{ft}$. deep and $12 \mathrm{ft}$. long and $3 \mathrm{ft}$. wide, located next to the shield water. Surrounding the sump are two baffles.

A screen slopes from the outer edge of the sump making contact with the shield wall. Inside the shield wall, screens cover passages $2^{\prime} \times 2^{\prime}$ leading to the outer annulus formed by the shield wall and containment wall. These inner screens contact the floor, inside the shield wall and slopes toward the shield wall.

For pipe breaks inside the shield wall, the pulerilidl for a larger amount of insulation debris reaching the emergency sump does not exist. Any insulation reaching the floor at El. 228'-0" inside the shield wall, must pass through the screens covering the drain passage. Therefore, to reach the outer annulus, insulation debris too large to pass through the screens would have to go through uncovered openings in the shield wall at elevations above the containment building water level after a LOCA. 
For a pipe break outside the shield wall, the potential for large amount of insulation debris reaching the emergency sump is very small for any breaks above El. 251.50. A floor at El. 251.50 will catch most of the insulation. A small amount of insulation will pass down stairwells and other openings. Below the 251.50 elevation, the insulation can float to the emergency sump. The baffles and sump screen will catch this insulation. 


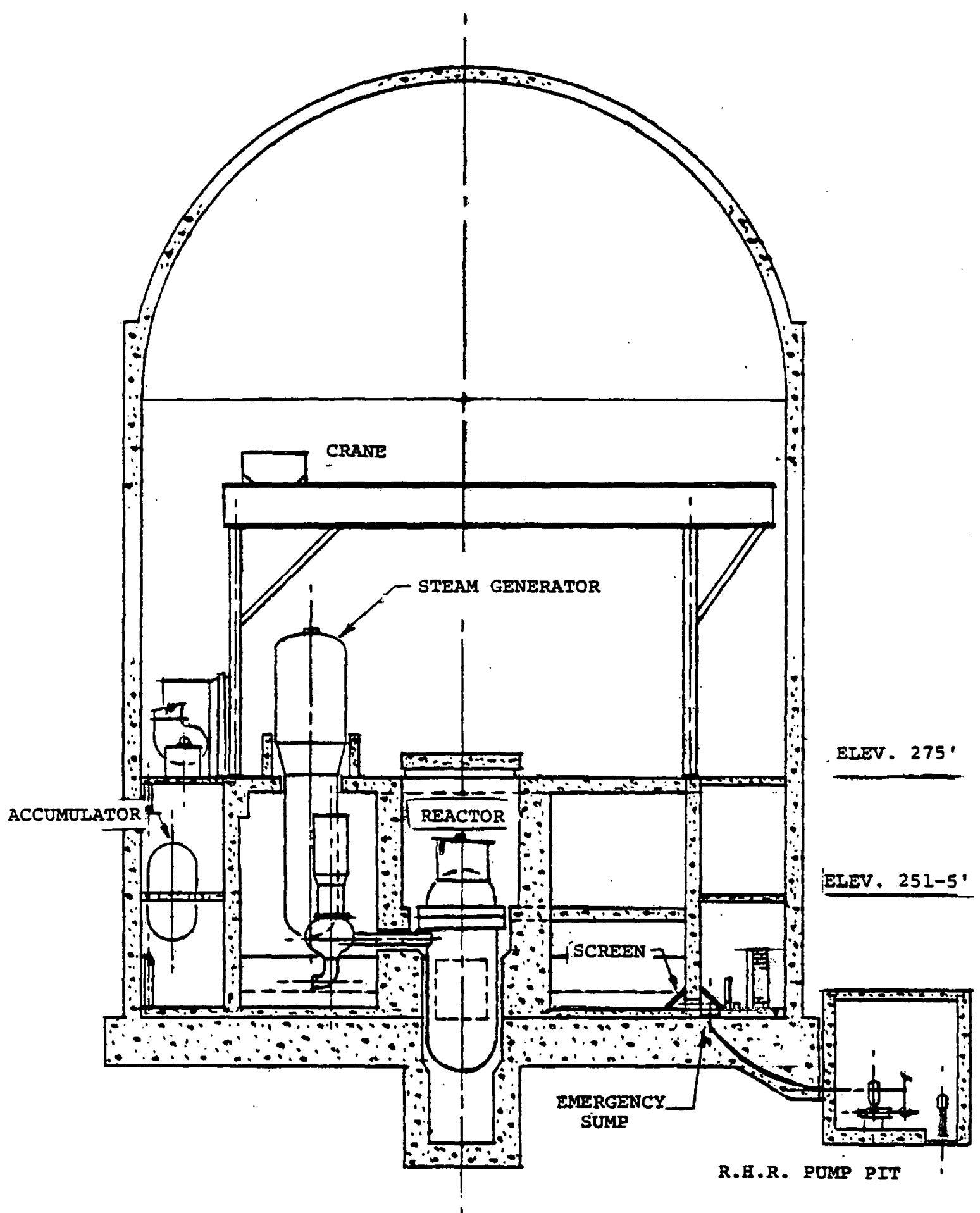

F'igure $\mathrm{I}-1$. Reactor Building Elevation, H. B. Robinson 


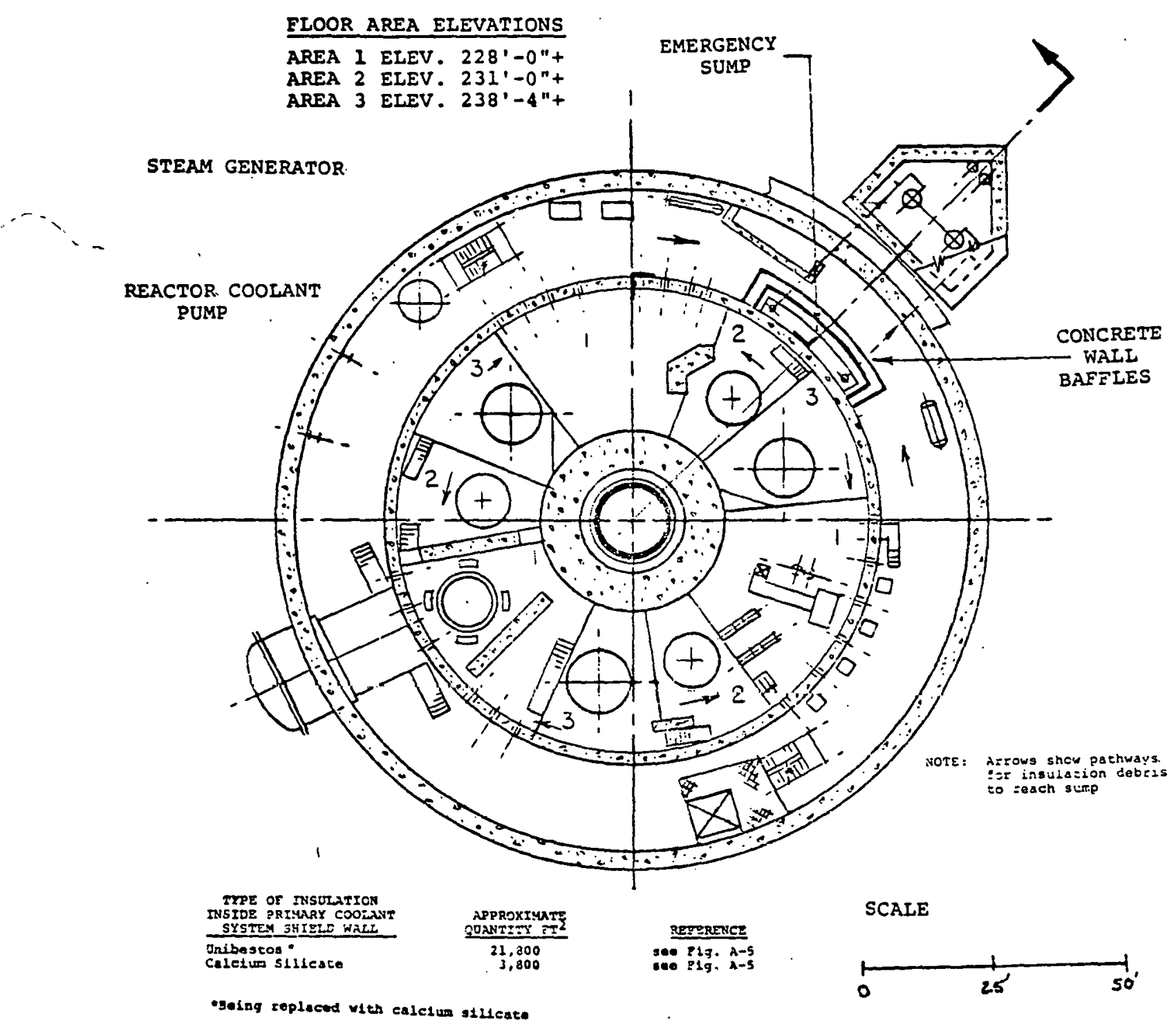

Figure I-2. Reactor Building Plan,

H. B. Robinson 


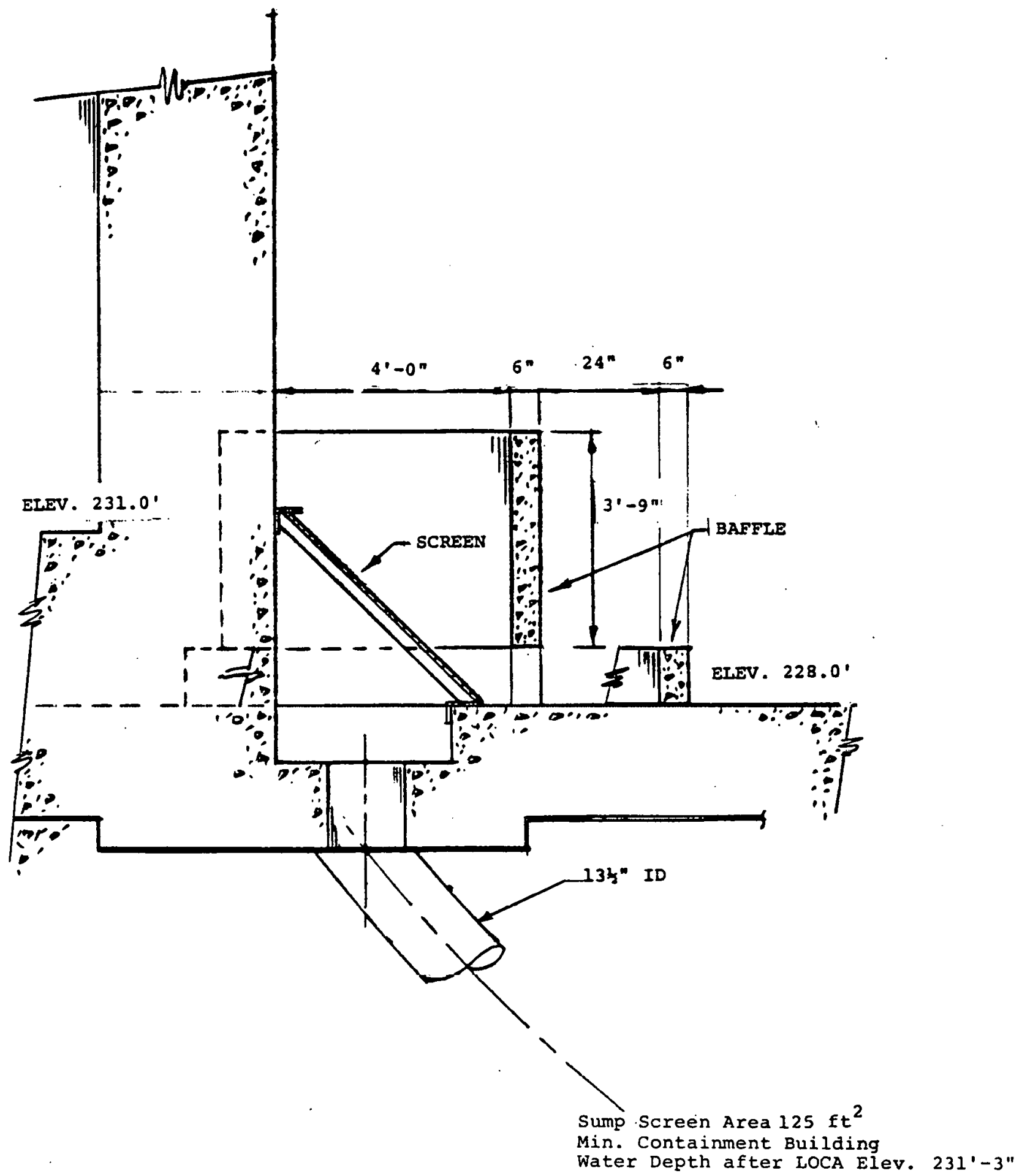

Figure I-3. Containment Sump, H. B. Robinson 


\section{UNITED STATES \\ NUCLEAR REGULATORY COMMISSION \\ WASHINGTON, D. C. 20555}

July 30, 1982

ERRATA SHEET

for

NUREG/CR-2403

SAND82-0927

Supplement No. 1

SURVEY OF INSULATION USED IN NUCLEAR POWER PLANTS

AND THE POTENTIAL FOR DEBRIS GENERATION

Prepared by

Burns and Roe, Inc. Under. Subcontract to

Sandia Nationat Laboratories

for the

U. S. Nuclear Regulatory Commission

Please replace the Legal Notice (found on the back of the title page) with the attached revised page.

DIVISION OF TECHNICAL INFORMATION

AND

DOCUMENT CONTROL

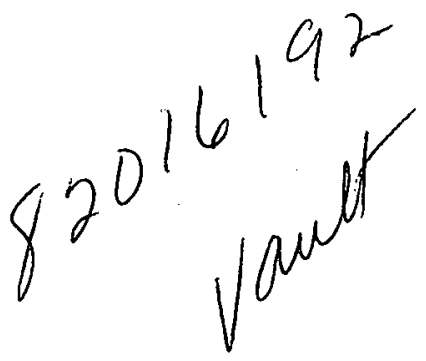




\section{LEGAL NOTICE}

This report was prepared by Burns and Roe, Inc., as part of work sponsored by the Sandia National Laboratories (Alburquerque). Conclusions or recommendations contained in this report may be predicated upon information published or officially sanctioned by, or received from, utility companies, without independent verification by Burns and Roe, Inc., Neither Sandia National Laboratories, Burns and Ro'e, Inc., nor any person acting on behalf of either: (a) makes any warranty or representation, express or implied, with respect to the accuracy, completeness, or suitability for any use or purpose of the information contained in this report, or that the use $e_{\text {, }}$ of any information, apparatus, method, or process disclosed in this report may not infringe privately owned rights, nor (b) assumes any responsibility for the use of information, apparatus, method, or process disclosed in this report. 


\author{
UNITED STATES \\ NUCLEAR REGULATORY COMMISSION \\ WASHINGTON, D. C. 20555
}

\title{
RECENED BY TIC AUG 251982
}

\author{
Juiy 30,1982
}

ERRATA SHEET

for

NUREG/CR-2403

SURVEY OF INSULATION USED. IN NUCLEAR POWER PLANTS

AND THE POTENTIAL FOR DEBRIS GENERATION

Prepared by

Burns and Roe, Inc.

for the

U. S. Nuclear Regulatory Commission

Please replace pages $5, F-6, I-4, I-7, I-8$, and $L-10$ with the attached revised pages. The Legal Notice is new and should be placed on the back of the title page.

DIVISION OF TECHNICAL INFORMATION

AND

UOCUMENT CONTROL
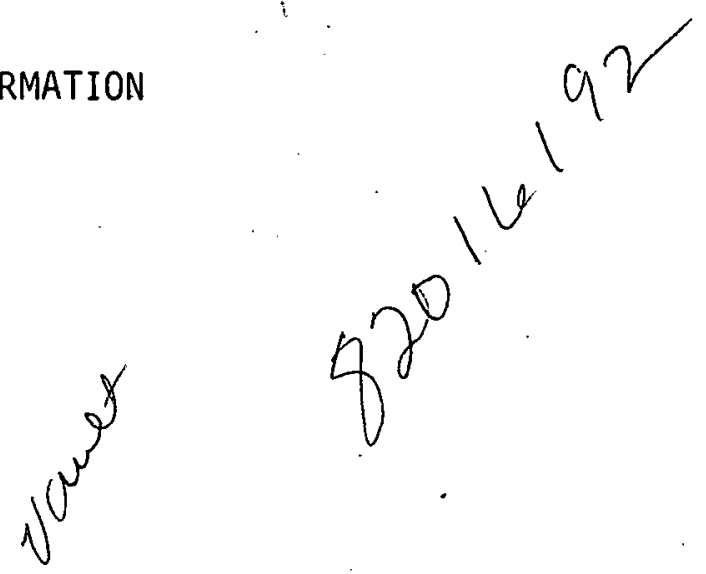
Table 3-1. Types and percentages of insulation used within the primary coolant system shield wall in plants surveyed

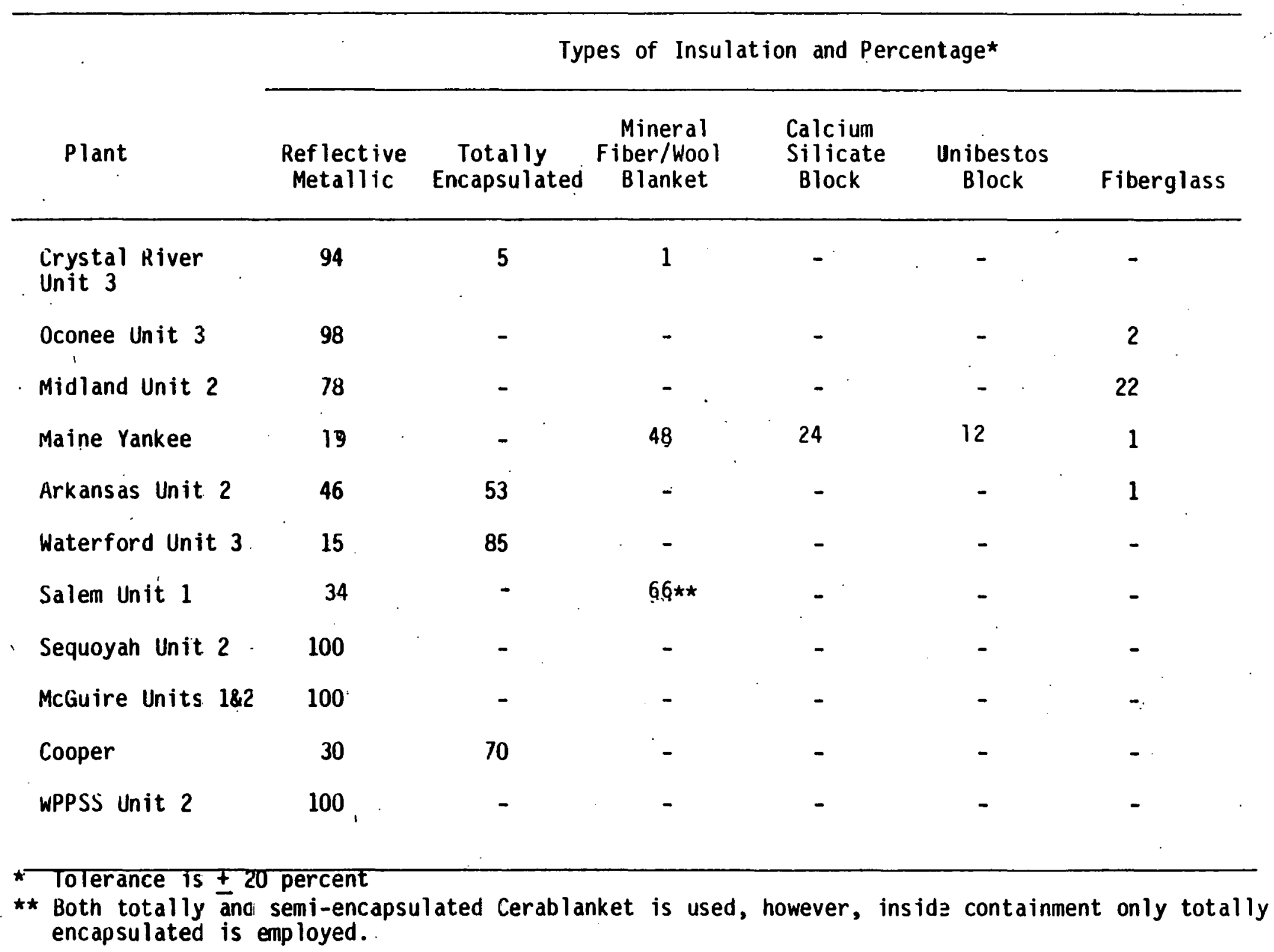




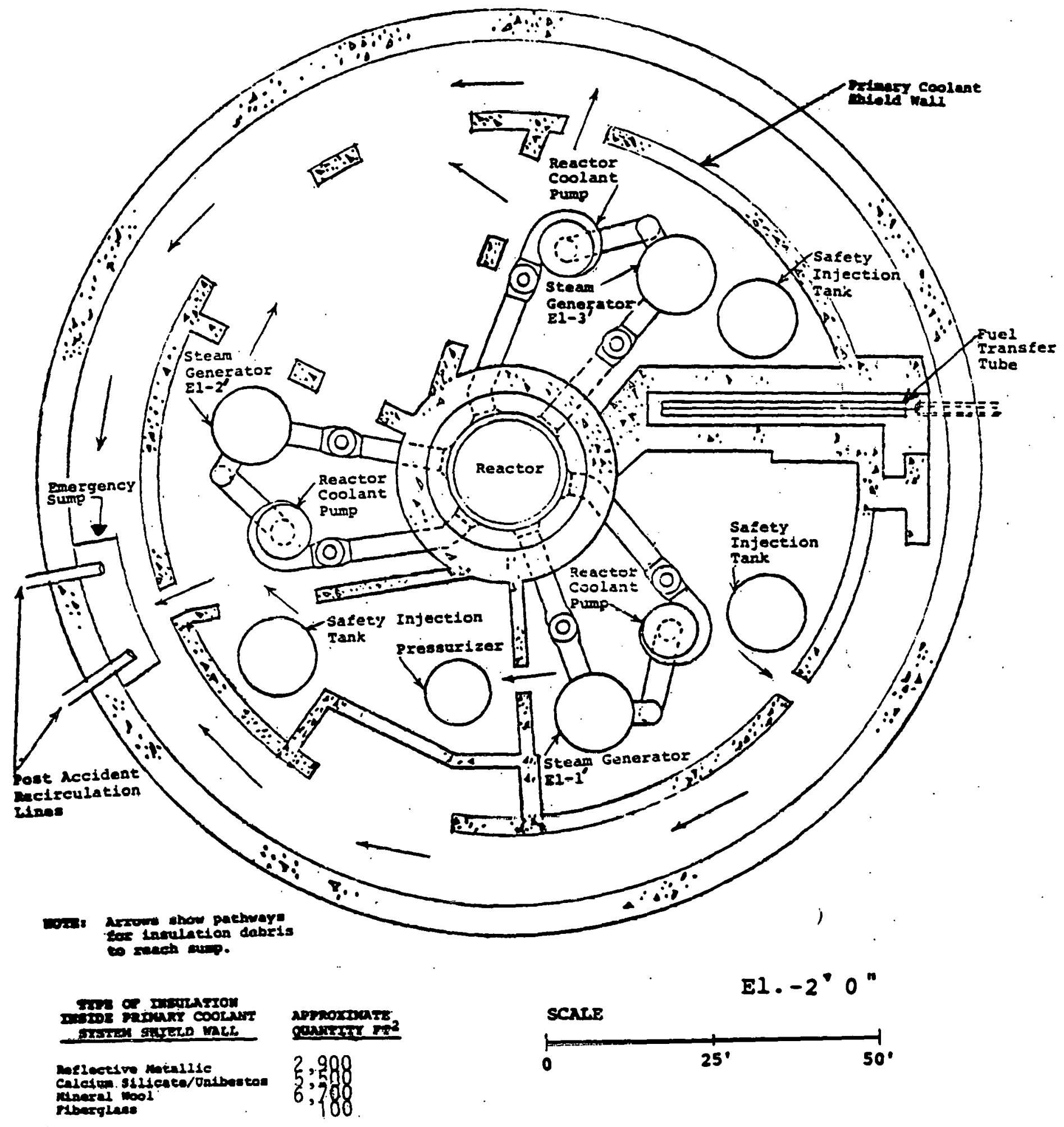

Figure F-2. Reactor containment, Maine Yankee 
Reflective metallic insulation is used for the reactor vessel, reactor coolant pump, pressurizer, and bottom area of the steam generators to one foot above the tube sheet. The upper part of the steam generator uses semiencapsulated cerablanket with stainless steel lagging. For systems connected to the primary coolant system, metallic reflective insulation is used out to the first isolation valve. After the first isolation valve, totally encapsulated Cerablanket (Johns-Manville product) is used for the safety injection, main steam, feedwater, residual heat removal, and chemical volume and control piping. Service water and component cooling-water piping inside containment is insulated with antisweat insulation. Information on the type of antisweat insulation used was not provided to Burns and Roe.

D. TYPICAL INSULATION DETAILS

The reflective metallic insulation used for primary coolant system equipment and piping was manufactured by Johns-Manville. It is similar in construction to the reflective insulation manufactured by Mirror and Transco.

E. PIPE BREAK LOCATIONS

Refer to the FSAR ${ }^{1}$ for a list of the pipe break locations for high-energy piping inside the primary containment.

\section{F. FSAR REFERENCES ON PERTINENT INSULATION QUESTIONS}

None were submitted by PSE\&G.

G. PRELIMINARY INSULATION DEBRIS HAZARD ANALYSIS

Figures I-1 and I-2. are simplified sketches of the Salem Unit 1 containment. The reactor vessel, lower part of the steam generators, pressurizer, reactor coolant pumps, and primary coolant piping are all located inside the shield wall. The accumulators, letdown heat exchanger, and regenerative heat exchangers are located outside the primary coolant shield wall. The emergency sump is located outside the shield wall below the basement floor with the bottom at elevation 70'-0" as shown in Figure I-3. Figure I-3 shows the details of the emergency sump. Figures $I-1$ and $I-2$ show the drainage trenches in the containment building. There are two trenches that are located in an inscribed circle around the building; one trench located inside the primary coolant shield wall and another trench located outside the primary coolant shield wall. Water drains into the trench through perforated pans with $3 / 16^{\prime \prime}$ diameter holes staggered on 5/16" centers. The outer trench drains into the sump through a 16" diameter pipe. The inner trench drains into the outer trench through a 12" diameter pipe. Both trenches are sloped toward the sump. Water also enters the sump directly from the annular space between primary coolant shield and containment walls through sets of cages and screens at the top of the sump pit as shown in Figure I-3. The RHR recirculation piping is protected from debris by the $3 / 16^{\prime \prime}$ diameter holes in perforated trench pans.

For a pipe break event near the upper portion of the steam generators, the floor at elevation $130^{\prime}$ will catch the insulation debris. For a pipe 


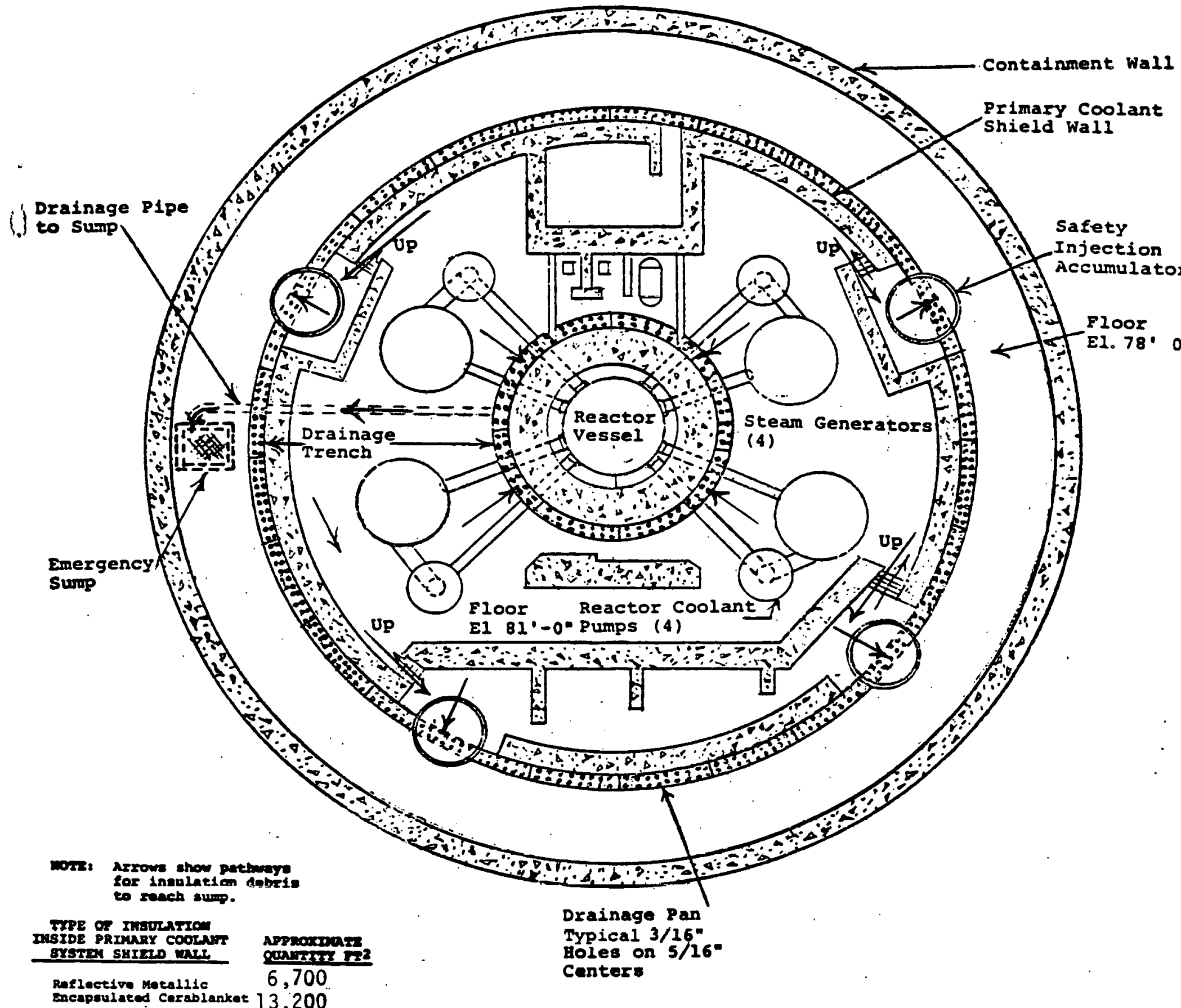

Figure I-2, Reactor containment arrangement plan view, Salem Unit 1 


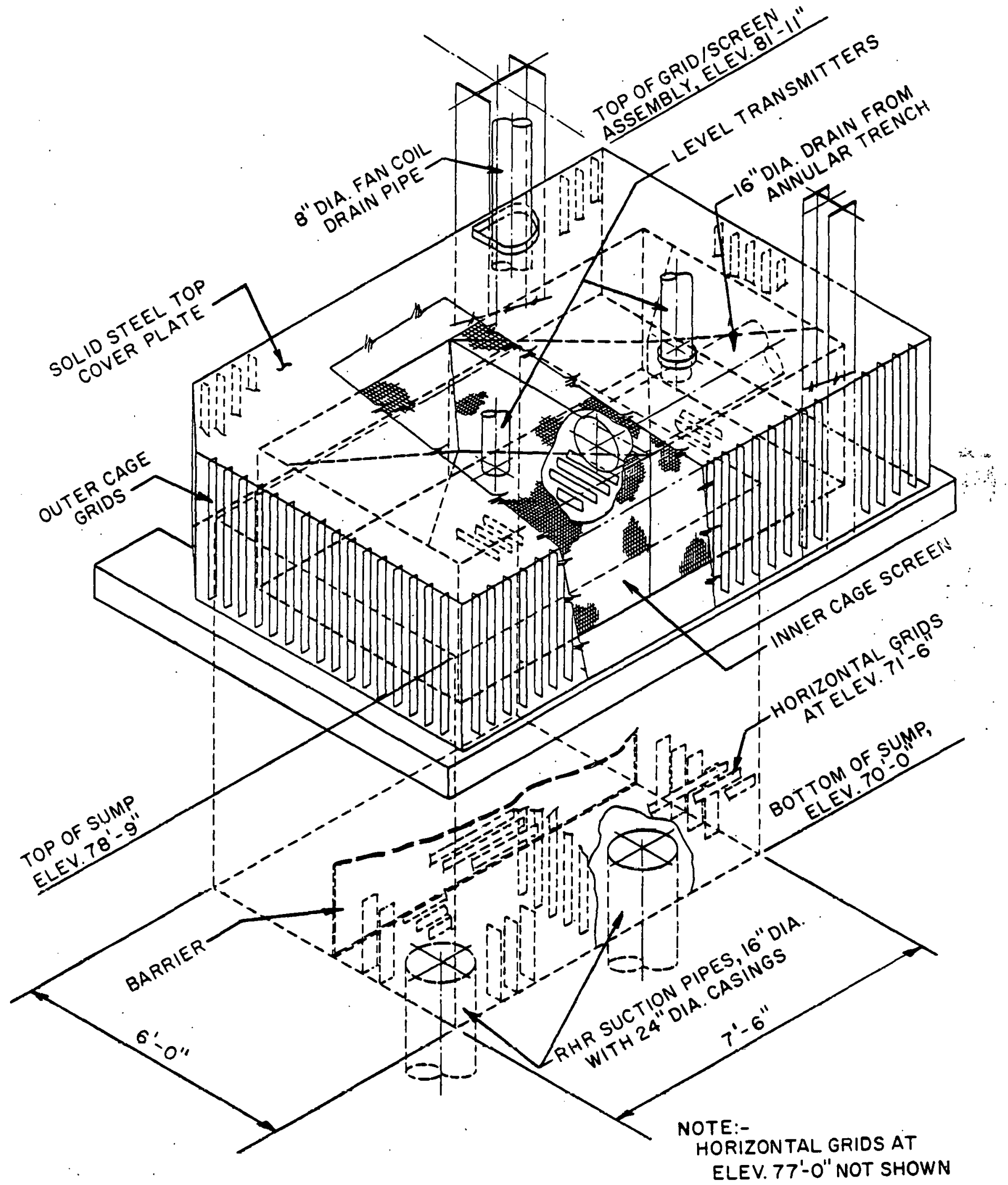

Figure I-3 Emergency Sump Detail, Salem Unit 1. 
If some insulation works its way into the vent pipe, it would still face a tortuous path to the torus. Each of the eight 5 foot 11 inch vent pipes terminates in a 4 foot 2 inch ring header located 26 feet from the drywell. Insulation debris must negotiate a $90^{\circ}$ turn upon reaching the ring header after sliding along a shallow angle in the vent pipe (Figure $L-5)$. Downcomers off the ring headers limit the insulation size still further (2l inch pipe) as seen in Figure L-9. A "lip" exists where the downcomers connect to the ring header, further adding to the difficulty for debris to enter a downcomer.

The geometry of the downcomer and the pump suction lines is shown in Figure L-8. The various suction line intakes of the emergency core-cooling system pumps have screens which have twice the flow area needed to allow for blockage of 50 percent of the screen area (see Figure L-10). The location of each intake screen in a different area of the wetwell along with its excess screening capacity makes it unlikely that more than one core cooling pump suction would be impacted by a postulated pipe break. Even then, it is doubtful that the debris would be in sufficient quantity to block the flow area required for safe operation of the pump involved.

\section{H. REFERENCES}

1. Cooper Station, Final Safety Analysis Report, Nebraska Public Power District, Columbus, Nebraska. 
LEGAL NOTICE

This report was prepared by Burns and Roe, Inc., as part of work sponsored by the Sandia National Laboratories (Álburquerque). Conclusions or recommendations contained in this report may be predicated upon information published or officially sanctioned by, or received from, utility companies, without independent verification by. Burns and Roe, Inc. Neither Burns and Roe, Inc., nor any person acting on its behalf: (a) makes any warranty or representation, express or implied, with respect to the accuracy, completeness, or suitability for any use or purpose of the information contained in this report, or that the use of any information, apparatus, method, or process disclosed in this report may not infringe privately owned rights, nor (b) assumes any responsibility for the use of information, apparatus, method, or process disclosed in this report. 